\title{
Zaitun
}

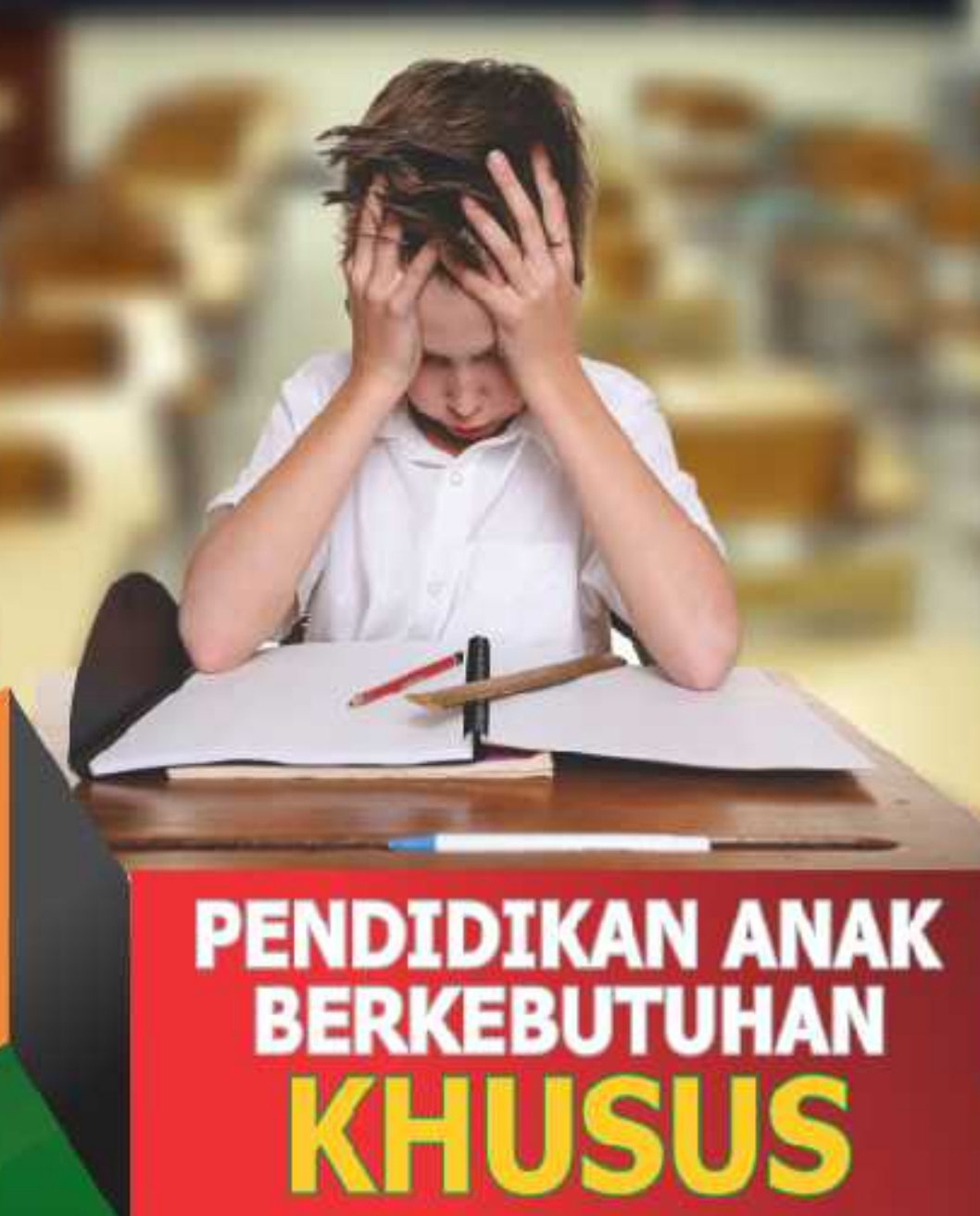


Zaitun

\section{PENDIDIKAN ANAK BERKEBUTUHAN KHUSUS}




\section{Katalog dalam Terbitan (KDT)}

\section{Pendidikan Anak Berkebutuhan Khusus}

Penulis : Zaitun

Layout : Jonri Kasdi

Design Cover : Mutiara Design

ISBN

vii, 146hal (205x145cm)

Cetakan Tahun 2017

\section{Kreasi Edukasi}

Publishing and Consulting Company

Jl. Swadaya Kom. Rindu Serumpun 4 Blok B-06

Kel. Delima Kec. Tampan - Pekanbaru

Mobile Phone : +6285216905750

\section{Lingkup Hak Cipta}

\section{Pasal 72}

1. Barang siapa dengan sengaja melanggar dan tanpa hak melakukan perbuatan sebagaimana dimaksud pasal 2 ayat 1 atau pasal 49 ayat 1 dan 2 dipidana penjara masing-masing paling singkat 1 bulan dan/atau denda paling sedikit Rp. 1.000.000,- atau pidana penjara paling lama 7 tahun dan/atau paling banyak Rp. 5.000.000.000,-

2. Barang siapa dengan dengaja menyiarkan, memamerkan, mengedarkan, atau menjual kepada umum suatu ciptaan atau barang hasil pelanggaran hak cipta sebagaimana dimaksud dalam ayat 1 , dipidana dengan penjara paling lam 5 tahun dan atau denda paling banyak Rp. 500.000.000,- 


\section{KATA PENGANTAR}

Alhamdulillah dan rasa syukur tidak terkira penulis sampaikan kehadirat illahi robbi, dimana penulisan buku ini akhirnya diselesaikan. Penulisan buku sangat membutuhkan waktu yang relatif panjang, dimana penulis harus bisa mengatur waktu sedemikian rupa terutama dalam mencari referensi yang medukung penyempurnaan buku ini.

Buku ini disusun sebagai bagian dari referensi yang dapat dipergunakan untuk menambah wawasan dan pengetahuan terutama bagi mahasiswa baik pada program strata satu (S1) maupun strata dua (S2) yang bergelut pada institusi keguruan. Beberapa materi buku ini penulis kembangkan sedemikian rupa secara bertahap sehingga menjadi buku" Pendidikan anak berkebutuhan khusus."

Penulis mengucapakan terima kasih kepada keluarga kecilku (suami dan anak-anak) yang selalu memberi suport agar penuli selalu berkarya meskipun ditengah kesibukan. Kepada pihak lain yang tidak dapat penulis sebutkan satu persatu, penulis ucapkan terima kasih atas segala kontribusi dan masukan sehingga penulisan buku ini menjadi sempurna dan selesai sesuai dengan waktu yang telahditetapkan. Penulis yakin bahwa buku ini masih jauh dari kesempurnaan, untuk itu kritikan, saran, dan masukan yang konstruktif dari berbagai pihak sangat diperlukan. Semoga buku ini bermanfaat bagi pembaca sekalian.

Wassalam,

Pekanbaru, 09 Agustus 2017

Penulis 


\section{DAFTAR ISI}

Kata Pengantar ....................................................................... ii

Daftar Isi ..................................................................................... iv

\section{BAB I}

\section{SEKILAS KONSEP PENDIDIKAN ANAK USIA DINI}

A. Konsep dasar Pendidikan anak Usia Dini ................ 1

B. Landasan pendidikan anak usia dini ................................. 8

C. Fungsi dan tujuan pendidikan anak usia dini _ ............. 13

D. Prinsip-prinsip melaksanakan pendidikan anak usia dini ............................................................................ 14

E. Arah kebijakan PAUD di Indonesia ................................... 16

F. Kondisi Dan Permasalahan Akses PAUD .......................... 17

G. Kebiajakan Dirjend Paudni Untuk Program PAUD....... 21

H. Fokus Kebijakan Paud (Nonformal Dan Informal)...... 30

I. Strategi Mewujudkan Paud Holistik Dan Terintegrasi Yang Bermutu.

\section{BAB II}

KONSEP DASAR PENDIDIKAN ANAK BERKEBUTUHAN KHUSUS (A CHILD SPECIAL NEED)

A. Konsep Anak Berkebutuhan Khusus.......................... 36

B. Memahami karakteristik ABK .................................. 40

C. Dasar Hukum ...................................................................... 41

\section{BAB III}

FAKTOR PENYEBAB DAN DAMPAK KELAINAN PADA ANAK BERKEBUTUHAN KHUSUS

A. Faktor-faktor penyebab kelainan pada anak berkebutuhan khusus 
B. Implikasi Terjadinya Anak Berkebutuhan Khusus

C. Masalah-Masalah Yang Dihadapi Anak Berkebutuhan Khusus

\section{BAB IV}

\section{KLASIFIKASI DAN KARAKTERISTIK ANAK BERKEBUTUHAN KHUSUS}

A. Kesulitan Belajar (Learning Disabilities) atau anak yang berprestasi rendah (Spesisific Learning Disability) ............................................................... 53

B. Tunarungu Wicara (Communcation Disorder and Deafness) ..................................................................... 53

C. Hiperactive (Attention Deficit Disorder with Hyperactive) ……....................................................... 54

D. Tunanetra (Partially Seing and Legally Blind) ....... 55

E. Tunalaras (Emotional or Behavioral Disorder) .... 56

F. Tunarungu Wicara (Communication Disorder and Deafetess).................................................................. 58

G. Karakteristik Anak Autistik (Autustic Child) ........ 58

H. Karakteristik Anak Tunadaksa atau Anak dengan Hendaya Fisik Motorik (Physical Disability)......... 61

I. Karakteristik Anak Tuna Ganda (Multiple Handicapped) ................................................................ 64

J. Karakteristik Anak Berbakat dan Berkebutuhan (Giftness and Special Tallented). 65

\section{BAB V}

MENGEKSPLORASI, MENGENAL, MENGIDENTIFIKASI DAN MENANGANI ANAK BERKEBUTUHAN KHUSUS GANDA (TWICE EXCEPTIONALITY)

A. Pengertian Keluarbiasaan ganda (twice exceptionality 68 
B. Identifikasi Anak dengan Twice Exceptionality ... 71

C. Keberbakatan ................................................................... 74

D. Faktor-faktor Pelindung ............................................. 75

E. Perlakukan anak-anak berkebutuhan khusus sama dengan anak-anak lainnya............................... 78

F. Assesmen dan Diagnosis............................................ 80

G. Dampak Emosional dan Psikologis............................ 83

H. Perkembangan akademis ............................................. 84

I. Layanan atau Bantuan/Intervensi ............................ 86

J. Proses Pembelajaran .................................................... 88

\section{BAB VI}

KARAKTERISTIK KELUARGA, PENGARUH DISABILITY

PADA KELUARGA, RESPON KELUARGA TERHADAP

DISABILITY, DAN PERAN KELUARGA BAGI PENDIDIKAN ANAK BERKEBUTUHAN KHUSUS
A. Peran keluarga ABK
94
B. Lingkungan Sekitar Rumah
C. Lingkungan Sekitar Sekolah.

\section{BAB VII}

PENDIDIKAN INKLUSI: MODEL ALTERNATIF LAYANAN PENDIDIKAN ANAK BERKEBUTUHAN KHUSUS
A. Pengertian Pendidikan Inklusi 99
B. Dasar Hukum Pendidikan Inklusi................................ 102
C. Tujuan pendidikn Inklusi .............................................. 104
D. Manfaat PAUD Inklusi .................................................... 106
E. Gagasan PAUD Inklusi .................................................... 107
F. Implementasi PAUD Inklusif di Lapangan .............. 108

\section{BAB VIII}

\section{PROGRAM PEMBELAJARAN KHUSUS UNTUK ABK}

A. Program Khusus Pembelajaran ABK.................................. 110

B. Kurikulum PAUD Inklusi ....................................................... 115 


\section{BAB IX}

\section{KONSEP LAYANAN PENDIDIKAN BAGI ANAK BERKEBUTUHAN KHUSUS}

A. Identifikasi layanan pendidikan anak
berkebutuhan khsusus ................................................. 118

Daftar Pustaka 



\section{BAB I \\ SEKILAS KONSEP \\ PENDIDIKAN ANAK USIA DINI}

\section{A. Konsep Dasar Pendidikan Anak Usia Dini}

Undang-undang Nomor 20 Tahun 2003 tentang Sistem Pendidikan Nasional menyebutkan bahwa pendidikan adalah usaha sadar dan terencana untuk mewujudkan suasana belajar dan proses pembelajaran agar peserta didik secara aktif mengembangkan potensi dirinya untuk memiliki kekuatan spritual keagamaan, pengendalian diri, kepribadian, kecerdasan, akhlak mulia, serta keterampilan yang diperlukan dirinya (pasal 1, butir 1).

Kita sering salah kaprah dalam menjembatani proses pendidikan anak, orangtua sering menganggap pendidikan sebenarnya adalah pendidikan yang diperoleh hanya melalui jalur pendidikan formal atau sekolah, sehingga kita melupakan pentingnya pendidikan anak usia dini (PAUD), yang notabene merupakan pendidikan paling penting dibanding pendidikan di usia sesudahnya.

Pendidikan Anak Usia Dini (PAUD) adalah suatu upaya pembinaan yang ditujukan kepada anak sejak lahir sampai dengan usia enam tahun yang dilakukan melalui pemberian rangsangan pendidikan untuk membantu pertumbuhan dan perkembangan jasmani dan rohani agar anak memiliki kesiapan dalam memasuki pendidikan lebih lanjut ( pasal 1, butir 14).

PAUD sebagai pendidikan yang diselenggarakan sebelum jenjang pendidikan dasar, memiliki kelompok sasaran anak usia 0-6 tahun yang sering disebut sebagai masa emas perkembangan (golden age). Masa ini hanya 
terjadi satu kali dalam kehidupan manusia dan tidak dapat ditangguhkan pada priode berikutnya. ${ }^{1}$ Inilah yang menyebabkan masa anak sangat penting dalam kehidupan manusia.

Pendidikan bagi anak usia dini sangat penting dilakukan, sebab merupakan dasar bagi pembentukan kepribadian manusia secara utuh, yaitu ditandai dengan karakter, budi pekerti luhur, pandai, trampil. Serta menitikberatkan pada peletakan, dasar kearah pertumbuhan dan perkembangan fisik (koordinasi motorik halus dan kasar, kecerdasan (daya fikir, daya cipta, kecerdasan emosi, kecerdasan spritual, sosio emosional (sikap dan prilaku serta agama, bahasa dan komunikasi sesuai dengan keunikan dan pertumbuhan anak usia dini disesuikan dengan tahap-tahap perkembangan yang dilaluinya ${ }^{2}$.

Usia 0-6 tahun adalah usia yang paling kritis atau paling menentukan dalam pembentukan karakter dan kepribadian seseorang. Termasuk juga pengembangan intelegensi hampir seluruhnya terjadi pada usia tersebut. Sejak anak dilahirkan hingga tahun-tahun pertama, anak mengalami pertumbuhan dan perkembangan yang sangat pesat. Para ahli berpendapat bahwa perkembangan pada tahun-tahun awal lebih kritis dibandingkan dengan perkembangan selanjutnya. Hasil penelitian Erickson yang melacak perkembangan anak dari bayi hingga dewasa

1 Direktorat Pendidikan Anak Usia Dini, Direktorat Jenderal Pendidikan Luar Sekolah dan Pemda, 2004, Konsep Dasar Pendidikan Anak Usia Dini, (Jakarta: Departemen Pendidikan Nasional ), h. 3

2 Direktorat Pendidikan Anak Usia Dini, Direktorat Jenderal Pendidikan Luar Sekolah dan Pemda, 2002, Acuan Menu Pembelajaran pada Pendidikan Anak Usia Dini (Jakarta: Departemen Pendidikan Nasional ), h. 1 
menyimpulkan bahwa "masa kanak-kanak merupakan gambaran awal manusia sebagai seorang manusia.

Para ahli neuroscience mengemukakan bahwa anak telah memiliki bermilyar sel neuron yang siap dikembangkan.Pertumbuhan sel jaringan otak terjadi sangat pesat pada tahun-tahun pertama kehidupan anak.Saat anak mencapai usia 4 tahun $80 \%$ jaringan otak tersusun. Jaringan tersebut akan berkembang dengan optimal jika ada rangsangan dari luar berupa pengalamanpengalaman yang dipelajari anak. Sebaliknya jaringan sel akan mati jika tidak diberikan rangsangan yang tepat. Oleh karena itu, para ahli neuroscience menyebut periode perkembangan masa ini sebagai masa emas (golden age).

Banyak para ahli menyebutnya masa tersebut golden age, yakni masa-masa keemasan yang dimiliki oleh seorang anak, atau masa dimana anak mempunyai potensi yang sangat besar untuk berkembang. ${ }^{3}$

Anak-anak pada usia dini tersebut memiliki intelegensi laten (potential intelegence) yang luar biasa. Namun pada umumnya orangtua dan guru hanya bisa mengajarkan sedikit hal pada anak-anak. Sesungguhnya anak-anak usia muda tidak "complicated" (ruwet) dalam belajar. Pada umumnya orangtua selalu menyalahkan anakanak apabila tingkah laku mereka tidak seperti yang kita inginkan. Hal ini lebih banyak disebabkan karena kurangnya pengetahuan dan pemahaman terhadap psychology (perkembangan jiwa anak), sehingga sering memperlakukannya dengan tidak/kurang tepat.

Anak-anak memiliki rasa ingin tahu yang luar biasa dan kemampuan untuk menyerap informasi sangat tinggi.

${ }^{3}$ M. Fadlillah., dkk, 2014, Edutainment Pendidikan Anak Usia Dini: Menciptakan pembelajaran menarik, kreatif dan menyenangkan, (Jakarta: Kencana Prenadamedia Group), h.21 
Kebanyakan orang tidak mengenali dan memahami kemampuan 'magic' yang ada pada anak-anak. Mereka hanya bisa berkata, "saya tahu anak-anak belajar lebih cepat", tetapi mereka tidak tahu seberapa cepat anak-anak bisa belajar. Karena keterbatasan pengetahuan dan kemampuan orangtua dan guru-guru maka potensi luar biasa yang ada pada setiap anak sebagian besar tersiasiakan.

Anak-anak usia dini memiliki bermilyar-milyar sel syaraf otak yang sedang berkembang dan memiliki kemampuan yang dahsyat, serta daya memory yang kuat. Maka pendidikan yang menanamkan nilai-nilai luhur kemanusiaan (pengembangan intelegensi/kecerdasan, karakter, kreativitas, moral, dan kasih sayang universal) sangatlah perlu diberikan pada anak-anak sejak usia dini. Oleh karena itu pendidikan Anak Usia Dini tidak boleh dianggap sepele dan diabaikan. Bahkan pendidikan bayi sejak usia nol tahun (baru lahir) atau bahkan sejak bayi masih dalam kandungan sudah saatnya dikembangkan. Guru-guru dan fasilitas yang terbaik semestinya diprioritaskan pada lembaga pendidikan kanak-kanak. Dedikasi yang tulus dari guru-guru dan dukungan sepenuhnya dari orangtua anak akan menjamin keberhasilan pendidikan anak-anak.

Para tenaga pendidik, baik di lingkungan pendidikan anak usia dini secara formal maupun non formal perlu memberikan pndekatan pendidikan yang holistic, pendekatan ini merupakan salah-satu alternatif yang sesuai untuk mengembangkan kurikulum pendidikan agama. ${ }^{4}$

${ }^{4}$ Ibnu Hadjar, 2001, "Pendekatan Holistik dalam Pendidikan Islam" dalam Paradigma Pendidikan Islam, (Yogyakarta: Pustaka Pelajar), h. 125. Dapat pula dilihat dalam Abd. Rahman Abdullah, 2001, Aktualisasi Konsep Dasar Pendidikan Islam; Rekonstruksi Pemikiran dalam Tinjauan Filsafat Pendidikan Islam, (Yogyakarta:UII Press ) 
Pendekatan holistik dapat dilakukan dari diri pribadi seorang guru, yang mana seorang guru dalam mengajarkan materi pelajaran harus terlebih dahulu mensucikan hati, pikiran dan jiwanya, diiringi oleh niat ikhlas untuk menyampaikan ilmu pengetahuan bagi para siswa. Tidak dapat dipungkiri bahwa dengan modal niat ikhlas, suci hati, telah banyak terbukti bahwa dengan cara ini para siswa lebih mudah menangkap apa yang disampaikan oleh guru, lebih mudah menyerap ilmu pengetahuan dan mengaplikasikannya secara tepat. Demikian tentunya aplikasinya bagi dunia pendidikan anak usia dini.

Dalam rangka merealisasikan langkah ini, dalam pandangan penulis, diperlukan adanya tatanan pendekaatan holistic, di mana prinsip-prinsipnya terdiri dari:

1. Adanya saling hubungan antar kenyataan dan kesatuan yang mendasar dari alam ini. Alam diibaratkan sebagai acuan yang suci dan sejalan dengan kodrat manusia. Seorang guru dalam menstransfer ilmu sebaiknya selalu memberikan renungan dan siraman rohani di sela-sela pemberian materi pelajaran. Guru harus mampu mendeteksi gejala psikis (kejiwaan) anak didik sehingga bisa menentukan kiat dan strategi apa yang akan diaplikasikan dalam pembelajaran. Hal semacam ini memang masih cukup langka, akan tetapi penulis merasa dengan cara ini para siswa justru akan lebih terpanggil untuk merenungi jati dirinya serta berusaha mengadaptasikan dirinya dengan alam.

2. Ada hubungan yang dalam antara diri seseorang dengan lingkungan alam sekitarnya. ${ }^{5}$ Dalam arti

${ }^{5}$ Louay Safi yang mengutip pendapat Karl Popper mengatakan bahwa metode naturalistik (kealaman) perlu memperhatikan berbagai 
alam merupakan kesatuan yang menyatu dengan manusia. Oleh karenaya kesatuan ini dianggap suci dan tidak dipengaruhi oleh hal-hal lain. Para siswa juga perlu ditanamkan kepada mereka bahwa semua makhluk di dunia ini merupakan bagian integral dari alam semesta. Oleh karenanya para siswa dan guru harus benar-benar menyatukan hati dan pikiran mereka penuh keikhlasan dan diikuti oleh kesucian diri.

Kesadaran akan pentingnya pendidikan anak sejak dini telah mendorong pemerintah, dalam hal ini Departemen Pendidikan Nasional untuk membentuk sebuah direktorat baru yang bernama Direktorat Pendidikan Anak Usia Dini yang berada dibawah Direktorat Pendidikan Luar Sekolah dan Pemuda. Tahun terakhir ini Depdiknas memusatkan perhatian dan menunjukkan keseriusan pada masalah pendidikan usia dini. Hal ini terlihat pada kebijakan pemrintah melakukan perluasan layanan PAUD dengan mensuport baik dalam sarana maupun prasarana serta bantuan dana rintisan maupun kelembagaan melalui dana APBN maupun APBD. Sebagai wujud dari amanat Undang-undang Dasar 1945 serta Undang-Undang Nomor 20 tahun 2003 tentang sistem pendidikan Nasional mengamanatkan dilaksanakannya

peristiwa yang berhubungan dengan alam, yang tentunya berakar pada konsepsi filosofis, lihat Louay Safi, 1996, The Foundation of Knowledge; a Comparative Study in Islamic and Western Methods of Inquiry, ( Kuala Lumpur:International Institute of Islamic Thought ), h. 155, lihat juga dalam Popper, 1985, "The Defence of Rationalisme" Selection, David Miller (Ed.), ( New Jersey: Princeton ), h. 33-35 
pendidikan kepada seluruh rakyat Indonesia sejak usia dini, yakni sejak dilahirkan. ${ }^{6}$

Oleh karena itu, kedua tatanan pendekatan pembelajaran di atas, dalam pandangan penulis sangat cocok diterapkan oleh pendidik yang bergelut pada dunia anak. Seorang pendidik mesti memulai segala sesuatu dengan tulus, ikhlas dan niat yang suci dalam mentransfer ilmunya kepada anak-anak usia dini. Pendidik juga mesti mengembangkan bakat dan minat anak-anak sesuai dengan karakteristik masing-masing, serta menghubungkan nilainilai berbasis keagamaan sesuai dengan latar belakang pendidikan keagamaan yang diperoleh anak didik (balita) dari orang tua. Pendidik yang profesional dan mengetahui ilmu jiwa dan perkembangan anak usia dini sudah tentu mampu menerapkan konsep-konsep keilmuan yang selevel dengan pencernaan anak-anak usia dini, dan diharapkan mereka mampu merealisasikan potensi-potensi anak dalam mencapai cita-cita mereka.

PAUD sebagai suatu wadah untuk menyiapkan generasi sejak dini memiliki pendekatan yang khas. Pendekatan tersebut disebut dengan BCCT (BEYOND CENTERS AND CIRCLES TIME) suatu pendekatan penyelenggaraan PAUD yang berfokus pada anak yang dalam proses pembelajarannya berpusat di sentra main dan saat anak dalam lingkaran dengan menggunakan 4 jenis pijakan (scaffoding) untuk mendukung perkembangan anak, yaitu pijakan lingkungan main, pijakan sebelum main, pijakan selama main dan pijakan setelah main.

6 Direktorat Pendidikan Anak Usia Dini, Direktorat Jenderal Pendidikan Luar Sekolah dan Pemda, 2004, Pentingnya sosialisasi Program PADU, ( Jakarta: Departemen Pendidikan Nasional ), h.2 
Besarnya pengaruh pendidikan di masa anak-anak (pre-school) yang dimungkinkan dapat mengembangkan potensi-potensi anak yang belum terungkap, terutama pada sejenis pendidikan anak usia dini (PAUD) Non formal.

\section{B. Landasan Pendidikan Anak Usia Dini}

Landasan pendidikan anak usia dini (PAUD) dapat dikategorikan kepada aspek yaitu sebagai berikut :

1. Landasan Yuridis

Landasan hukum tentang pentingnya PAUD (pendidikan anak usia dini) tersirat dalam amandemen UUD 1945 pasal 28 b ayat 2, yaitu: negara menjamin kelangsungsungan hidup, pengembangan dan perlindungan anak terhadap eksploitasi dan kekerasan. Amandemen UUD 1945, Pasal 28 c ayat 2, tertulis bahwa setiap anak berhak mengembangkan diri melalui pemenuhan kebutuhan dasarnya, berhak mendapatkan pendidikan dan memperoleh manfaat dari ilmu pengetahuan dan teknologi seni dan budaya demi meningkatkan kualitas hidupnya dan demi kesejahteraan umat manusia.

Selain itu, secara khusus pemerintah juga mengeluarkan UU No. 20/2003 tentang Sistem Pendidikan Nasional, PP No. 27/1990 tentang Pendidikan Prasekolah, PP No. 39/1992 mengenai peran serta masyarakat dalam pendidikan nasional.Sebagai bagian dari masyarakat internasional, pemerintah Indonesia telah terkait komitmen dengan berbagai peraturan maupun konvensi internasional yang terkait dengan hak asasi anak. Berbagai komitmen tersebut telah mengikat bakan telah diratifikasi. Beberapa isu global seperti pemenuhan hak-hak dasar anak (CRC-20 Nopember 1989), pencegahan diskriminasi dan adanya persamaan hak bagi anak dan wanita (CEDAW-18 
Desember 2000), perlu nilai-nilai Ilahi yang bersifat universal yang harus ditanamkan pada anak-anak (United Nations Millenium Declaration - 8 Desember 2000), memberikan kesempatan yang lebih luas bagi anak untuk berprestasi dalam pengambilan dan pemenuhan hak-hak dasar anak (The World Fit for Children -8 Mei 2002), program pembinaan dan pengembangan anak-anak dini usia menjadi isu yang sangat pentiung dalam agenda nasional. ${ }^{7}$ Kemudian UU Perlindungan Anak (No.23 tahun 2002)

UU Sisdiknas No.20 tahun 2003, tertulis bahwa pendidikan anak usia dini adalah suatu upaya yang ditujukan bagi anak sejak lahir sampai dengan usia enam tahun yang dilakukan melalui pemberian rangsangan pendidikan untuk membantu pertumbuhan dan perkembangan jasmani dan rohani agar anak memiliki kesiapan dalam memasuki pendidikan lebih lanjut.

Pada bagian ketujuh pasal 28 tertuamg bahwa: ${ }^{8}$

a) Pendidikan anak usia dini diselenggarakan sebelum jenjang pendidikan dasar,

b) PAUD diselenggarakan tiga jalur (formal, nonformal dan informal)

c) PAUD jalur pendidikan formal berbentuk TK, RA atau bentuk lain yang sederajat

d) PAUD jalur pendidikan nonformal berbentuk kelompok bermain, taman penitipan anak, bentuk lain yang sederajat

e) PAUD jalur pendidikan informal berbentuk pendidikan keluarga atau pendidikan yang diselenggarakan oleh lingkungan.

${ }^{7}$ Ibid., h. 15-16

8Undang-undang Sisdiknas edisi terbaru 2012,

(Bandung:Fukosindo) 
2. Landasan Empiris

Berdasarkan sensus penduduk tahun 2003, diperkirakan jumlah,

a. Anak dini usia (0-6 tahun) di Indonesia adalah 26,17 juta jiwa. Dari 13,50 juta anak usia 0-3 tahun yang terlayani melalui layanan Bina Keluarga Balita sekitar 2,53 juta $(18,74 \%)$.

b. Anak usia 4-6 tahun dengan jumlah 12,67 juta, yang terlayani melalui Taman Kanak-kanak (TK), Raudhatul Athfal (RA), Kelompok Bermain, dan Penitipan Anak sebanyak 4,63 juta (36,54\%). Artinya baru sekitar 7,16 juta (27,36\%) anak yang terlayani PADU melalui berbagai program PADU, sehingga dapat disimpulkan masih terdapat sekitar 19,01 juta $(72,64 \%)$ anak usia dini yang belum terlayani PADU. ${ }^{9}$

Rendahnya tingkat partisipasi anak mengikuti pendidikan anak dini usia berdampak pada rendahnya kualitas sumber daya manusia Indonesia. Menurut laporan UNDP tentang Human Development Index (HDI) pada tahun 2002 Indonesia menempati peringkat 110 dari 173 negara dan 111 pada tahun 2004, jauh di bawah negara ASEAN lain seperti Malaysia (59), Philipina (77), Thailand (70), bahkan peringkat Indonesia berada di bawah Vietnam.

Rendahnya kualitas sumber daya manusia Indonesia diikuti juga dengan terpuruknya kualitas pendidikan di segala bidang dan tingkatan. Berdasarkan hasil studi "kemampuan membaca siswa" tingkat SD yang dilaksanakan International Achievement (IEA) diketahui bahwa siswa SD di Indonesia beradacdi urutan ke 38 dari 39 negara. Hasil penelitian International Mathematics and Science Study Repeat tahun 1999, kemampuan siswa kita di

${ }^{9}$ Ibid, h. 16 
bidang IPA berada di urutan 32 dari 38 negara yang diteliti dan di bidang matematika berada di urutan 34 dari 38 negara yang diteliti.

\section{Landasan Keilmuan}

Pentingnya PAUD didukung oleh penelitianpenelitian tentang kecerdasan otak. Seorang bayi yang baru lahir memiliki kurang lebih 100 miliar sel otak. Ini menunjukkan selama 9 bulan masa kehamilan, paling tidak setiap menit dalam pertumbuhan otak diproduksi $250 \mathrm{ribu}$ sel otak. Sel-sel otak dibentuk berdasarkan stimulasi dari luar otak. Setiap sel otak saling terhubung dengan lebih dari 15 ribu simpul elektrik kimia yang sangat rumit sehingga bayi yang berusia 8 bulan pun diperkirakan memiliki biliunan sel saraf di dalam otaknya. Sel-sel saraf ini harus rutin distimulasi dan didayagunakan supaya terus berkembang jumlahnya.

Pada usia rawan saat anak mulai banyak bergerak, yaitu usia 6 bulan, angka kecelakaan dapat berkurang sebanyak $80 \%$ bila mereka diberi rangsangan dini. Pada umur 3 tahun, anak-anak akan mempunyai IQ 10 sampai 20 poin lebih tinggi dibandingkan dengan mereka yang tidak pernah mendapatkan stimulasi. Pada usia 12 tahun, mereka tetap memperoleh prestasi yang baik dan pada usia 15 tahun, tingkat intelektual mereka semakin bertambah. Ini memberi gambaran bahwa pendidikan sejak dini memberi efek jangka panjang yang sangat baik. Sebaliknya, bila anak mengalami stress pada usia-usia awal pertumbuhannya akan berpengaruh pada perkembangan otaknya. Pengalaman yang tidak menyenangkan akan membekas lama dan cukup memberi efek mengubah komposisi sel di dalam otak. Anak yang dibesarkan di dalam lingkungan 
yang minim stimulasi, berkurang kecerdasannya selama 18 bulan yang tidak mungkin tergantikan. ${ }^{10}$

Secara alamiah perkembangan anak berbeda-beda, baik dalam intelegensi, bakat, minat, kreativitas, kematangan emosi, kepribadian, keadaan jasmani dan keadaan sosialnya. Namun penelitian tentang otak menunjukkan bahwa bila anak distimulasi sejak dini, maka akan ditemukan genius (potensi paling baik/ unggul) dalam dirinya. Setiap anak memiliki kemampuan tak terbatas dalam belajar (limitless capacity to learn) dalam dirinya untuk dapat berpikir kreatif dan produktif. Oleh karena itu, anak memerlukan program pendidikan yang mampu membuka kapasitas tersembunyi tersebut (unlocking the capacity) melalui pembelajaran bermakna seawal mungkin. Bila potensi pada diri anak tidak pernah terealisasikan berarti anak telah kehilangan peluang dan momentum penting dalam hidupnya, dan pada gilirannya negara akan kehilangan sumber daya manusia terbaiknya. Dalam konteks inilah peranan pendidikan anak dini usia perlu mendapat perhatian serius.

\section{Landasan Teoritis}

Hakikat anak usia dini adalah sebagai berikut:

a. Kelompok manusia yang berusia $0-6$ tahun (di Indonesia berdasarkan UU No. 20 Tahun 2003 tentang Sisdiknas). Berdasarkan para pakar pendidikan anak usia dini, yaitu kelompok manusia yang berusia 0 - 8 tahun

b. Kelompok anak yang berada dalam proses pertumbuhan dan perkembangan yang bersifat unik. Artinya, memiliki pola pertumbuhan dan perkembangan fisik (koordinasi motorik halus

10Ibid., h. 20 
dan kasar), kecerdasan (daya pikir, daya cipta, kecerdasan emosi, kecerdasan spritual), sosioemosional (sikap dan perilaku serta agama), bahasa dan komunikasi yang khusus sesuai dengan tingkat pertumbuhan dan perkembangan yang sedang dilalui oleh anak

c. Berdasarkan keunikan dalam tingkat pertumbuhan dan perkembangannya, anak usia dini terbagi dalam tiga tahapan, yaitu: (1) masa bayi, usia lahir-12 bulan; (2) masa toddler (balita) usia 1- 3 tahun; (3) masa prasekolah usia 3-6 tahun; dan (4) masa kelas awal SD usia 6-8 tahun.

d. Pertumbuhan dan perkembangan anak usia dini perlu diarahkan pada peletakan dasar-dasar yang tepat bagi pertumbuhan dan perkembangan manusia selanjutnya, yaitu pertumbuhan dan perkembangan fisik daya pikir, daya cipta, sosioemosional, bahasa dan komunikasi yang seimbang sebagai dasar pembentukan pribadi. ${ }^{11}$

\section{Fungsi dan Tujuan Pendidikan Anak Usia Dini}

Pendidikan anak usia dini (PAUD) memiliki fungsi utama mengembangkan semua aspek perkembangan anak, meliputi perkembangan kognitif, bahasa, fisik (motorik kasar dan halus), sosial dan emosional. PAUD berfungsi membina, menumbuhkan, dan mengembangkan seluruh potensi anak usia dini secara optimal sehingga terbentuk perilaku dan kemampuan dasar sesuai dengan tahap perkembangannya agar memiliki kesiapan untuk memasuki pendidikan selanjutnya.

11Ibid,. h. 9-10 
Sehubungan dengan fungsi-fungsi yang telah dipaparkan tersebut, maka tujuan pendidikan anak usia dini dapat dirumuskan sebagai berikut: ${ }^{12}$ Pertama, memberikan pengasuhan dan pembimbingan yang memungkinkan anak usia dini tumbuh dan berkembang sesuai dengan usia dan potensinya. Kedua, mengidentifikasi kemungkinan penyimpangan yang memungkinkan terjadi sehingga jika terjadi penyimpangan, dapat dilakukan intervensi dini. Ketiga, menyediakan pengalaman yang beraneka ragam dan mengasyikkan bagi anak usia dini yang memungkinkan mereka mengembangkan potensi dalam berbagai bidang, sehingga siap untuk mengikuti pendidikan pada jenjang sekolah dasar.

Keempat, membangun landasan bagi berkembangnya potensi peserta didik agar menjadi manusia beriman dan bertakwa pada Tuhan Yang Maha Esa, berakhlak mulia, sehat, berilmu, cakap, kritis, kreatif, inovatif, mandiri, percaya diri, serta menjadi warga negara yang demokratis dan bertanggung jawab. Kelima, mengembangkan potensi kecerdasan spritual, intelektual, emosional, dan sosial peserta didik pada masa pertumbuhannya dalam lingkungan bermain yang edukatif dan menyenangkan.

\section{Prinsip-prinsip Melaksanakan Pendidikan Anak Usia Dini}

Penyelenggaraan pendidikan anak usia dini didasarkan atas prinsip-prinsip sebagai berikut: (a) Berorientasi pada kebutuhan anak. Kegiatan pembelajaran harus selalu ditujukan pada pemenuhan kebutuhan

12 Imam Musbikin, 2010, Buku Pintar PAUD:Tuntunan Lengkap dan praktis para Guru PAUD, (Jogjakarta: Laksana), h.47 
perkembangan anak secara individu; (b) Kegiatan belajar dilakukan melalui bermain. Dengan bermain yang menyenangkan merangsang anak untuk melakukan eksplorasi dengan menggunakan bena-benda yang ada di sekitarnya, sehingga anak menemukan pengetahuan dari benda-benda yang dimainkannya; (c) Merangsang munculnya kreativitas dan inovasi. Kreativitas dan inovasi tercermin melalui kegiatan yang membuat anak tertarik, fokus, serius dan konsentrasi; (d) Menyediakan lingkungan yang mendukung proses belajar. Lingkungan harus diciptakan menjadi lingkungan yang menarik dan menyenangkan bagi anak selama mereka bermain; (e) Mengembangkan kecakapan hidup anak. Kecakapan hidup diarahkan untuk membantu anak menjadi mandiri, disiplin, mampu bersosialisasi, dan memiliki keterampilan dasar yang berguna bagi kehidupannya kelak; (f) Menggunakan berbagai sumber dan media belajar yang ada di lingkungan sekitar; (g) Dilaksanakan secara bertahap dan berulangulang dengan mengacu pada prinsip-prinsip perkembangan anak; (h) Rangsangan pendidikan bersifat menyeluruh yang mencakup semua aspek perkembangan. Setiap kegiatan anak sesungguhnya dapat mengembangkan berbagai aspek perkembangan/ kecerdasannya. Tugas pendidik (guru/kader/pamong) adalah memfasilitasi agar semua aspek perkembangan anak dapat berkembang secara optimal. ${ }^{13}$

${ }^{13}$ Departemen Pendidikan Nasional, 2006, Beyond enters and Circles Time (BCCT); Pendekatan Sentra dan Saat Lingkaran dalam Pendidikan Anak Usia Dini, Uakarta: Direktorat Jenderal Pendidikan Luar Sekolah Direktorat Pendidikan Anak Usia Dini ), h. 4-5, lihat juga dalam Yayasan Pendidikan Muslimat NU Bina Bakti Wanita Pusat (YPMNU), 2007, Kurikulum PAUD Formal dan Non Formal, (Jakarta:Direktorat Jenderal Pendidikan Islam Direktorat Pendidikan Madrasah bekerja sama dengan YPMN), h. 42 


\section{E. Arah Kebijakan PAUD di Indonesia}

Arah kebijakan PAUD di Indonesia dilihat dari: Visi, adalah (1) mengupayakan pemerataan pelayanan, peningkatan mutu, dan efisiensi penyelenggaraan pendidikan dini, (2) mengupayakan peningkatan kesadaran dan kemampuan masyarakat dalam memberikan layanan pendidikan dini, (3)mempersiapkan anak sedini mungkin agar kelak memiliki kesiapan memasuki pendidikan lanjut. ${ }^{14}$ Sedangkan Misi adalah terwujudnya anak usia dini yang cerdas, sehat, ceria, dan berakhlak mulia serta memiliki kesiapan fisik maupun mental dalam memasuki pendidikan lebih lanjut.

Berbagai bentuk kebijakan dan kesepakatan baik secara nasional maupun internasional telah mendorong pemerintah untuk menyusun berbagai program yang terkait dengan pengasuhan, pendidikan, dan pengembangan anak usia dini. Sebagai wujud nyata komitmen pemerintah adalah beberapa kebijakan dasar yang memuat dalam dokumen Program Nasional bagi Anak Indonesia (PNBAI) sampai 2015, yang isinya antara lain: (1) mewujudkan anak yang sehat, tumbuh dan berkembang secara optimal melalui pemberdayaan masyarakat, peningkatan kerjasama lintas sektoral, perbaikan lingkungan, peningkatan kualitas serta jangkauan upaya kesehatan, peningkatan sumber daya, pembiayaan dan manajemen kesehatan, serta pengembangan ilmu pengetahuan dan teknologi; (2) mewujudkan perlindungan dan partisipasi aktif anak melalui perbaikan mutu pranata sosial dan hukum, pemerataan dan perluasan jangkauan

14Yuliani Nuraini Sujiono, Konsep Dasar Pendidikan Anak Usia Dini, h.49 
pelayanan terutama bagi anak yang berada dalam keadaan darurat dalam jaringan kerja nasional dan internasional. ${ }^{15}$

\section{F. Kondisi dan Permasalahan Akses PAUD}

Pembentukan anak sehat secara jasmani perlu disertai dengan pembentukan dan pengembangan aspek psikologis, emosional, dan mentalnya melalui pendidikan yang terencana dan terarah sejak dini. Masyarakat Indonesia telah menyadari pentingnya pendidikan anak usia dini dan berbagai lembaga pendidikan anak usia dini yang telah marak di daerah perkotaan sampai ke pedesaan. Sungguhpun demikian, pendidikan di Indonesia masih mengalami berbagai permasalahan dan tantangan yang perlu penanganan lebih lanjut.

Berbagai masalah yang ada, seperti: tingkat partisipasi anak usia dini (4-6 tahun) yang masih rendah, kesempatan memperoleh pendidikan anak usia dini masih belum merata dan terkonstrasi di daerah perkotaan dan lebih diminati dan dinikmati oleh masyarakat ekonomi menengah atas, sumber-sumber untuk pendidikan dan perawatan anak usia dini, kurangnya tenaga pendidik dan kependidikan dari segi jumlah dan mutu. ${ }^{16}$

Persepsi tentang pentingnya golden age, yaitu $80 \%$ kapasitas perkembangan dicapai pada usia dini (lahir sampai usia delapan tahun), sedangkan selebihnya (20\%) diperoleh setelah usia depalan tahun belum tepat dan benar. Akibatnya, banyak orangtua dan guru berlomba

${ }^{15} \mathrm{Fasli} \mathrm{Jalal,} \mathrm{2010,} \mathrm{Arah} \mathrm{kebijakan} \mathrm{nasional} \mathrm{pendidikan} \mathrm{anak} \mathrm{usia}$ dini (jalur pendidikan nonformal), (Jakarta, Semiloka Nasional PAUD) 16Mukhtar Latif dkk, 2013, Orientasi Baru Pendidikan Anak Usia Dini, ( Jakarta: Prenadamedia Group), h.28 
dengan waktu untuk memberikan pengalaman belajar melalui "kegiatan atau pembelajaran akademik". Hamper keseluruhan waktu belajar anak dilakukan melalui "kegiatan akademik". Guru mengajar denfan menjelaskan, anak belajar melalui mendengarkan dan mengerjakan tugas didominasi lembar atau buku kerja anak. Anak menulis angka dan huruf/kata tanpa membangun konteks belajar terlebih dahulu. Dalam situasi ini, aspek koginitif atau intelektual memperoleh stimulasi terbesar, sedang aspek lainnya, seperti emosi, sosial, dan seni hamper diabaikan. Ini sebagaimana yang dinyatakan dalam permasalahan kondisi PAUD dari Dirjen PAUDNI yang menyatakan:

1. Proses pembelajaran masih diwarnai dengan pengajaran baca-tulis-hitung (Calistung) dan belum sepenuhnya melalui bermain.

2. Kompetensi pendidik masih rendah: pelatih pendidik baru menjangkau 118.018 orang (29.32\%) dari 402.493 orang (di luar guru TPQ).

3. Kualifikasi pendidik PAUD belum memadai (S1/D4 baru $15.72 \%$ ).

4. Jumlah lembaga PAUD rujukan/imbas mutu masih terbatas, yaitu baru sekitar 346 lembaga (0.3\%) dari 114.888 lembaga.

5. Kondisi sarana dan prasarana sebagian besar PAUD memprihatinkan.

Persepsi yang belum tepat dan benar tentang golden age perkembangan masa usia dini mengakibatkan bermain terabaikan. Sebenarnya, bermain sebagai salah satu kebutuhan dasar perkambangan anak. Kalau kebutuhan belum terpenuhi anak akan kesulitan mencapai perkembangan yang optimal. Oleh karena itu, kegiatan belajar perlu dikemas dalam kegiatan bermain dan melalui kegiatan bermain. Hasil pengamatan penulis menunjukkan bahwa banyak kegiatan belajar yang belum dilakukan 
dalam kegiatan dan suasana bermain. Bermain juga belum sebagai strategi atau "kendaraan" belajar anak. Pelaksanaan pembelajaran pada AUD yang lebih terfokus pada kegiatan akademik dan mengabaikan kegiatan bermain sebagai suatu praktik PAUD yang kelitu. Bermain bukan hanya sebagai "kendaraan" belajar anak. Bermain sebagai salah satu kebutuhan perkembangan anak. ${ }^{17}$

Situasi kelas yang menunjukkan adanya masalah, seperti anak TK tidak mau berbagi mainan ini, tetapi dapat disebabkan tahap perkembangan anak belum sampai ke bermain bersama walau usia kalendernya telah menunjukkan anak berada pada tahap perkembagan bermain bersama. Masalah ini dapat disebabkan karena kegiatan bermain yang diperoleh anak sangat minim. Masalah ini juga menjadi salah satu keluhan yang banyak dialami guru TK, RA, atau KB.

Pembelajaran seperti yang dikemukakan di atas banyak terjadi di PAUD formal (TK dan RA) dan nonformal (KB, TPA, dan sejenis lainnya). Pembelajaran lebih menekankan pada aspek akademik (baca, tulis, hitung) yang dilakukan secara akademik pula. Guru menerangkan/menjelaskan, anak diam dan mendengarkan, dan anak diminta untuk bekerja atau menuis lembaran kerja (worksheet). Banyak guru beranggapan tanpa menerangkan atau menjelaskan materi anak akan kesulitan memperoleh pengetahuan. Anak memperoleh pengetahuan justru dari berbagai cara. Sesuai dengan salah satu ciri anak usia dini, yaitu anak sebagai individu yang aktif maka pengetahuan lebih banyak diperoleh dari pengealaman melakukan berbagai aktivitas. Mendengarkan penjelasan guru sedikit sekali membentuk pengetahuan apalagi usia

${ }^{17}$ Ibid, h. 31 
anak yang belum dapat berkonsentrasi dalam waktu yang relatif lama.

Pengalaman penulis bertemu dengan guru dalam berbagai kegiatan dan hasil pengamatan dalam kegiatan belajar. Beberapa guru AUD menjelaskan bahwa guru mengaku telah melaksanakan kegiatan bermain sambil belajar dan belajar melalui bermain. Namun kegiatan bermain dilakukan adalah kesempatan bermain diberikan pada saat jam istirahat, sedang pada saat pembukaan, inti, dan penutup cenderung sepenuhnya dilakukan dalam kegiatan akademik.

Sebenarnya, banyak pendekatan, model, dan metode pembelajaran yang dapat diterapkan di PAUD. Pendekatan, model, dan metode yang dikemukakan para pilsuf, seperti pendidikan model Frobel, Montessori, dan lainnya sebagai model yang dikembangkan berdasarkan gabungan berbagai filosofi dan teori ahli juga ada, di antaranya model PAUD high scope dan Religio Emilia.

Perlu kejadian guru dalam melakukan pemilihan atau pengembangan pendekatan, model, dan metode pembelajaran. Pemahaman guru tentang model-model PAUD akan mewarnai pemilihan atau pengembangan pendekatan, model, dan metode pembelajaran yang digunakan untuk anak usia dini. Untuk ini guru perlu memahami berbagai model PAUD meliputi aspek filosofi dan teori dari setiap model, bagaimana pendekatan, dan metode pembelajaran setiap model PAUD.

Berkenaan dengan kompetensi pendidik masih rendah disebabkan pertama karena memang program PAUD dilaksanakan dari masyarakat yang notabene memanfaatkan sumber daya lokal yang dirasa mampu mengurusi anak-anak, tidak melihat dari tamatan apa, kualifikasi guru PAUD yang seharusnya dipersyaratkan. Ada ibu rumah tangga yang mau, tidak terkecuali tamatan SLTP 
sederajat SLTA sederajat, bahkan lulusan paket b atau c dari kader-kader Posyandu banyak terlibat di kegiatan KB, SPS, dan TPA, wajar saja mutu dan kualitas PAUD masih dipertanyakan. Diperlukan kebijakan yang berkesinambungan dan berkelanjutan melaksanakan pelatihan/workshop dan peningkatan kualifikasi pendidik PAUD ini.

\section{G. Kebijakan Dirjend PAUDNI Untuk Program PAUD}

Strategi layanan PAUD selayaknya dimulai sejak masa kehamilan ibu, di mana orangtua (calon ibu dan calon ayah) mendapatkan pendidikan tentang bagaimana mendidik anak usia dini yang berorientasi pada kebutuhan anak melalui dunianya yaitu bermain, dan bagaimana orangtua dapat menjadi model untuk pembelajaran karakter bagi anak yang dimulai dari orangtua itu sendiri. Setelah anak lahir (nol) sampai dengan usia delapan tahun anak berhak mendapatkan PAUD secara terpadu, selain orangtua anak juga mendapat bimbingan dari pengasuh, guru pendamping, dan guru sebagai PTK (Pendidik dan Tenaga Kependidikan). Proses pembelajaran yang diberikan sesuai dengan kebutuhan anak, yang mengutamakan proses ketimbang hasil.

Namun prioritas layanan yang menjadi dilemma saat ini adalah pembelajaran yang berorientasi pada keinginan orangtua, bukan pada kebutuhan anak, sehingga yang terjadi di lapangan banyak kita temukan pembelajaran anak usia dini yang mengajarkan calistung (baca-tulis-hitung), pemaksaan proses pembelajaran di mana guru mengejar tercapainya kurikulum yang mereka buat sendiri dan lebih mementingkan hasil daripada proses pembelajaran. Hal ini dikarenakan orangtua takut anak mereka tidak mampu dalam tes penerimaan siwa di SD (sekolah dasar) yang 
mereka anggap favorit dan tertinggal dalam mengikuti pembelajarannya di sekolah, sehingga anak mereka tidak saling bersaing dengan anak-anak lainnya. Kekhawatiran yang seperti inilah yang membuat orangtua banyak menuntut anak mereka diajarkan calistung pada saat mereka di PAUD. Diharapkan dengan adanya strategi layanan PAUD yang direncakana oleh Dirjen PAUDNI yang didasari pula oleh PP No. 17 Tahun 2010 yang menyatakan bahwa penerimaan Siswa SD/MI tidak berdasarkan tes calistung atau sejenisnya, maka layanan PAUD dapat terlaksana sebagaimana mestinya pendidikan anak usia dini tersebut diselenggarakan.

Target APK PAUD Nasional yang diharapkan oleh DIrjen PAUDNI dapat dilihat dalam tabel berikut ini:

\section{Target APK PAUD Nasional}

Tahun 2011-2015

\begin{tabular}{|l|c|c|r|r|}
\hline Tahun & $\begin{array}{c}\text { Anak Usia } \\
\text { Tahun 0-6 } \\
\text { Tahun }\end{array}$ & $\begin{array}{c}\text { Perkiraaan } \\
\text { Terlayani }\end{array}$ & $\begin{array}{c}\text { Tambahan } \\
\text { Akses }\end{array}$ & APK(\%) \\
\hline 2009 & 28.854 .400 & 15.493 .470 & 783.788 & $53.9 \%$ \\
\hline 2010 & 28.912 .400 & 16.393 .331 & 899.681 & $56.7 \%$ \\
\hline 2011 & 30.113 .300 & 18.098 .093 & 1.704 .763 & $60.1 \%$ \\
\hline 2012 & 30.375 .100 & 19.318 .564 & 1.220 .470 & $63.6 \%$ \\
\hline 2013 & 30.359 .200 & 20.462 .101 & 1.143 .537 & $67.4 \%$ \\
\hline 2014 & 30.338 .700 & 22.116 .912 & 1.654 .812 & $72.9 \%$ \\
\hline 2015 & 30.312 .500 & 23.189 .063 & 1.072 .150 & $76.5 \%$ \\
\hline
\end{tabular}

Untuk dapat mencapai target dari perencanaan yang telah dibuat, maka PAUDNI membuat program-program yang diharapkan selain menambah serapan APK juga dapat memenuhi kebutuhan layak akan pendidikan anak usia dini (PAUD). Untuk itu, PAUDNI membuat dan mengembangkan 
program gerakan nasional yang berkaitan dengan pembelajaran dan peserta didik, sarana dan prasarana, serta kelembagaan PAUD. Hal tersebut dapat dilihat melaui tabel-tebel berikut ini:

\section{Pembelajaran dan Peserta Didik}

Program yang Dikembangkan

\begin{tabular}{|l|l|}
\hline \multicolumn{1}{|c|}{ Program } & \multicolumn{1}{c|}{ Kegiatan } \\
\hline 1. Penguatan & - Mengintegrasikan \\
pendidikan karakter. & pendidikan karakter \\
& dalam keseluruhan \\
& proses pembelajaran \\
& PAUD. \\
& - Mengembangkan bahan \\
& dan alat pendidikan \\
& karakter dalam \\
& berbagai media. \\
\hline 2. Diversifikasi pola & - Mengembangkan bahan \\
pembelajaran yang & pembelajaran berbasis \\
sesuai dengan budaya & kearifan lokal. \\
dan potensi daerah. & - Mengembangkan \\
& sistem pembelajaran \\
& berbasis budaya dan \\
& potensi daerah. \\
\hline 3. Penyiapan bahan dan & - Mengembangkan bahan \\
media pembelajaran. & pembelajaran melalui \\
& media cetak dan video. \\
& - Mengembangkan \\
& sistem pembelajaran \\
& PAUD berbasis $e-$ \\
& learning. \\
\hline
\end{tabular}




\section{Pembelajaran dan Peserta Didik}

\section{Program Gerakan Nasional PAUD}

\begin{tabular}{|l|l|}
\hline \multicolumn{1}{|c|}{ Kegiatan } & \multicolumn{1}{|c|}{ Subkegiatan } \\
\hline $\begin{array}{l}\text { 1. Diversifikasi pola } \\
\text { pembelajaran yang } \\
\text { sesuai dengan bidaya } \\
\text { dan potensi daerah. }\end{array}$ & $\begin{array}{c}\text { - Mengembangkan } \\
\text { bahan pembelajaran } \\
\text { berbasis kearifan lokal. } \\
\text { - Mengembangkan } \\
\text { sistem pembelajaran } \\
\text { berbasis budaya dan } \\
\text { potensi daerah. }\end{array}$ \\
\hline 2. Penguatan layanan & - Pemberian makanan \\
kesehatan dan gizi & tambahan (PMTAS). \\
(PAUD holistic- & Memperluas layanan \\
integratif). & PAUD holistic- \\
& integratif melalui pos \\
& PAUD dan BKB (BIna \\
& Keluarga Balita), da \\
& satuan PAUD lainnya. \\
& - Memperluas PAUD \\
& holistic-integratif \\
& percontohan di setiap \\
& kabupaten/kota. \\
\hline 3. Penguatan program & Meningkatkan \\
parenting PAUD. & pelaksanaan program \\
& pengasuhan \\
& (parenting) di satuan \\
& PAUD. \\
& - Memperluas program \\
& pelatihan "parenting" \\
& bagi orangtua yang \\
& mempunyai anak usia \\
& 0-2 tahun. \\
\hline
\end{tabular}




\section{Sarana dan Prasarana}

Program Gerakan Nasional PAUD

\begin{tabular}{|c|c|}
\hline Kegiatan & Subkegiatan \\
\hline $\begin{array}{l}\text { 1. Pemenuhan } \\
\text { prasarana PAUD. }\end{array}$ & $\begin{array}{l}\text { - } \text { Mengembangkan } \\
\text { standardisasi prasarana } \\
\text { PAUD. } \\
\text { - Memberikan bantuan } \\
\text { pembangunan fasilitas } \\
\text { PAUD terpadu. } \\
\text { - Memberikan bantuan } \\
\text { pembangunan lembaga } \\
\text { PAUD percontohan. } \\
\text { - Memberikan bantuan } \\
\text { rehabilitasi fasilitas } \\
\text { PAUD. } \\
\text { - Memberikan bantuan } \\
\text { perluasan ruang belajar } \\
\text { dan penunjang lainnya. }\end{array}$ \\
\hline $\begin{array}{l}\text { 2. Pemenuhan sarana } \\
\text { belajar PAUD. }\end{array}$ & $\begin{array}{l}\text { - } \text { Mengembangkan } \\
\text { standardisasi sarana } \\
\text { PAUD (APE dalam dan } \\
\text { APE luar). } \\
\text { - Memberikan bantuan } \\
\text { bahan ajar PAUD. } \\
\text { - Memberikan bantuan } \\
\text { alat permainan edukatif } \\
\text { (APE) PAUD. }\end{array}$ \\
\hline
\end{tabular}




\section{Kelembagaan}

\section{Program Gerakan Nasional PAUD}

\begin{tabular}{|c|c|}
\hline Kegiatan & Subkegiatan \\
\hline $\begin{array}{l}\text { 1. Penataan } \\
\text { kelembagaan PAUD. }\end{array}$ & $\begin{array}{l}\text { - Memfasilitasi lembaga } \\
\text { PAUD mencapai standar } \\
\text { nasional. } \\
\text { - Membantu berdirinya } \\
\text { lembaga PAUD } \\
\text { percontohan tingkat } \\
\text { kabupaten/kota dan } \\
\text { kecamatan. } \\
\text { - Melakukan penilaian } \\
\text { kinerja dan/atau } \\
\text { akreditasi satuan PAUD. }\end{array}$ \\
\hline $\begin{array}{l}\text { 2. Peningkatan mutu } \\
\text { lembaga PAUD. }\end{array}$ & $\begin{array}{l}\text { - Mengembangkan } \\
\text { standardisasi sarana } \\
\text { PAUD (APE dalam dan } \\
\text { APE luar). } \\
\text { - Memberikan bantuan } \\
\text { bahan ajar PAUD. } \\
\text { - Memberikan bantuan } \\
\text { alat permainan edukatif } \\
\text { (APE) PAUD. }\end{array}$ \\
\hline $\begin{array}{l}\text { 3. Pengintegrasian } \\
\text { berbagai layanan } \\
\text { PAUD menjadi PAUD } \\
\text { terpadu. }\end{array}$ & $\begin{array}{l}\text { - Membuka layanan KB } \\
\text { atau TPA di lembaga } \\
\text { TK/RA/BA yang sudah } \\
\text { ada, dan sebaliknya. } \\
\text { - Mengintegrasikan } \\
\text { layanan PAUD dengan } \\
\text { layanan kesehatan, gizi, } \\
\text { dan perlindungan anak. }\end{array}$ \\
\hline
\end{tabular}




\section{Pembelajaran dan Peserta Didik}

Program Gerakan Nasional PAUD

\begin{tabular}{|c|c|}
\hline Kegiatan & Subkegiatan \\
\hline $\begin{array}{l}\text { 1. Diversifikasi pola } \\
\text { pembelajaran yang } \\
\text { sesuai dengan } \\
\text { budaya dan } \\
\text { potensi daerah. }\end{array}$ & $\begin{array}{l}\text { - Mengembangkan } \\
\text { bahan pembelajaran } \\
\text { berbasis kearifan lokal. } \\
\text { - Mengembangkan } \\
\text { sistem. pembelajaran } \\
\text { berbasis budaya dan } \\
\text { potensi daerah. } \\
\end{array}$ \\
\hline $\begin{array}{l}\text { 2. Penguatan layanan } \\
\text { kesehatan dan gizi } \\
\text { (PAUD holistic- } \\
\text { integratif). }\end{array}$ & $\begin{array}{l}\text { - Pemberian makanan } \\
\text { tambahan (PMTAS). } \\
\text { - Memperluas layanan } \\
\text { PAUD holistic- } \\
\text { integratif melalui Pos } \\
\text { PAUD dan BKB (bina } \\
\text { keluarga balita), dan } \\
\text { satuan Paud lainnya. } \\
\text { - Memperluas PAUD } \\
\text { holistik-integratif } \\
\text { percontohan di setiap } \\
\text { kabupaten/kota. }\end{array}$ \\
\hline $\begin{array}{l}\text { 3. Penguatan program } \\
\text { parenting PAUD. }\end{array}$ & $\begin{array}{l}\text { - } \text { Meningkatkan } \\
\text { pelaksanaan program } \\
\text { pengasuhan (parenting) } \\
\text { di satuan PAUD. } \\
\text { - Memperluas program } \\
\text { pelatihan "parenting" } \\
\text { bagi orangtua yang } \\
\text { mempunyai anak usia 0-2 } \\
\text { tahun. }\end{array}$ \\
\hline
\end{tabular}


Berangkat dari kondisi nyata pendidikan anak usia dini tersebut, untuk mengarahkan terwujudnya sistem pendidikan sebagai pranata sosial yang kuat dan berwibawa, pemerintah telah menetapkan kebijakan pembangunan pendidikan anak usia dini dalam Renstra Kementrian Pendidikan Nasional 2009-2014. Kebijakan tersebut mencakup pendidikan usia dini jalur pendidikan formal dan nonformal dan berfokus pada kegiatan pokok dalam mendukung perluasan dan pemerataan akses PAUD yang bermutu dan berkesetaraan gender disemua provinsi, kabupaten, dan kota, yaitu dalam bentuk bantuan biaya operasional (BOP) peserta didik TPA/KB/SPS, bantuan rintisan PAUD, dan bantuan alat permainan edukasi (APE) PAUD, penyelengaraan lomba/pemilihan mitra PAUD berprestasi, peningkatan tata kelola melalui kegiatan pengembangan SIM PAUD, penyelenggaraan supervise, pelaporan, pemantauan, dan evaluasi.

Kegiatan pokok dalam mendukung perluasan dan pemerataan akses TK/TKLB bermutu dan berkesetaraan gender di semua provinsi, kabupaten, dan kota adalah penyediaan sarana dan prasarana, rehabilitasi sarana dan prasarana sekolah, penyelenggaraan festival dan kompetisi, peningkatan tata kelola TK melalui MBS, pembinaan.

Kebijakan strategis dalam pembangunan pendidikan anak usia dini ini dijadikan acuan dalam penyusunan dan melaksanakan berbagai program untuk mengatasi secara bertahap masalah dan tantangan dalam pendidikan anak usia dini. Dalam menentukan prioritas dan pengembangan program pendidikan anak usia dini secara nasional, diperlukan kajian-kajian yang objektif, actual dan kontekstual pada tatanan kebijakan, pelaksanaan, dan hasil yang dicapai. Kajian yang dimaksud mencakup semua bidang dan unsur dalam pendidikan anak usia dini dan hasilnya menjadi umpan balik dalam merumuskan 
kebijakan, merencanakan dan melaksanakan program lebih lanjut.

\section{PAUD Terpadu}

Target atau sasaran program PAUD Terpadu adalah lembaga/organisasi yang telah menyelenggarakan salah satu program layanan PAUD (TK, KB, PA, SPS), dan selanjutnya berkeinginan untuk mengembangkan program layanan PAUD lainnya.

\section{PAUD Holistik Integratif}

Kebijakan Direktorat PAUD, Direktur PAUD, Ditjen PNFI, Depdiknas Tahun 2009. Amanat UU No. 20 Tahun 2003 (UU Sisdiknas). Pasal 1 Butir 14 (Pengertian PAUD). Pendidkan anak usia dini (PAUD) adalah "suatu upaya pembinaan yang ditujukan kepada anak sejak lahir sampai dengan usia enam tahun yang dilakukan melalui pemberian rangsangan pendidikan untuk membantu pertumbuhan dan perkembangan jasmani dan rohani agar anak memiliki kesiapan dalam memasuki pendidikan lebih lanjut.

\section{Tupoksi Direktorat PAUD (Permendiknas No. 31} Tahun 2007)

Tugas pokok Dit. PAUD melaksanakan penyiapan bahan perumusan kebijakan, pemberian bimbingan teknis, dan evaluasi di bidang PAUD nonformal dan informal. 


\section{H. Fokus Kebijakan Paud (Nonformal Dan Informal)}

- Perluasan \& Pemerataan Akses

- Memberdayakan semua potensi yang ada di masyarakat

- Berpihak kepada masyarakat yang kurang beruntung

- Peningkatan mutu, relevansi \& daya saing

- Mengupayakan PAUD yang murah, mudah, tetap bermutu

- Peningkatann tata kelola, akuntabilitas, \& citra public

- Keterbukaan, kemudahan, dan fleksibiltas di bidang layanan PAUD kepada masyarakat.

\section{Program Pokok Direktorat Paud}

\section{PAUD Nonformal}

\section{a. Taman Penitipan Anak (TPA)}

Salah satu bentuk PAUD pada jalur pendidikan nonformal yang menyelenggarakan program penfifikan sekaligus pengasuhan dan kesejahteraan sosial terhadap anak sejak lahir sampai dengan usia enam tahun (dengan prioritas anak usia empat tahun ke bawah).

\section{b. Kelompok Bermain (KB)}

salah satu bentuk PAUD pada jalur pendidikan nonformal yang menyelenggarakan program pendidikan sekaligus program kesejahteraan bagi anak sejak lahir sampai dengan enam tahun (dengan prioritas anak usia dua sampai empat tahun). 


\section{c. Satuan PAUD Sejenis (SPS)}

Semua layanan PAUD nonformal selain TPA dan KB diberi nama satuan PAUD sejenis atau SPS. SPS dapat dilaksanakan secara terintegrasi dengan berbagai program layanan anak usia dini yang ada di masyarakat (seperti posyandu, Bina Keluarga Balita atau BKB, Taman Pendidikan AlQuran atau TPQ, Taman Pendidikan Anak Saleh atau TAPAS, Sanggar Pendidikan Anak Saleh atau SPAS, Bina Anak Prasa, Sekolah Minggu, Bina Iman, dan semua layanan anak usia dini yang berada di bawah binaan lembaga agama lainnya, serta semua lembaga layanan anak yang berada di bawah binaan organisasi wanita/organisasi sosial/kemasyarakatan).

Salah satu bentuk SPS yang merupakan pengintegrasian antara posyandu/BKB dengan PAUD disebut "Pos PAUD".

\section{PAUD Infromal}

PAUD Berbasis Keluarga

a. Arah:

1) Agar orangtua/keluarga dapat melanjutkan stimulasi pendidikan yang diterima anak di lembaga PAUD.

2) Agar sebelum anak dikirim ke lembaga PAUD sudah mendapatkan layanan PAUD yang benar orangtua,keluarganya.

3) Agar masyarakat lebih peduli dan/atau bisa mendukung terhadap layanan PAUD di lingkungannya.

Ada delapan fungsi keluarga, yakni: agama, sosial budaya, ekonomi, kasih sayang, pemeliharaan 
lingkungan, dan sosialisasi (UU Bo. 10 Tahun 1992) pendidikan, reproduksi.

b. Focus:

Fasilitas terhadap aspek stimulasi pendidikan kepada para orangtua/keluarga, antara lain:

1) Pemahaman tentang esensi stimulasi pendidikan

2) Sasaran stimulasi pendidikan

3) Metode/teknik stimulasi pendidikan

4) Pelaksanaan stimulasi pendidikan

c. Pendekatan:

1) Holistik meliputi: gizi, kesehatan, pendidikan dan lain-lain

2) Terintegrasi

Program PAUD merupakan bagian yang tak terpisahkan dalam keseluruhan stimulasi dan/atau layanan terhadap tumbuh kembang anak disemua program layanan anak usia dini yang ada di msyarakat.

3) Prinsip Pembelajaran: pemberian stimulasi pendidikan melalui pendekatan bermain sambil belajar.

4) Esensi Stimulasi Pendidikan: bermain aktif setiap hari, penuh kasih sayang, gembira, berulang, konsisten, bervariasi, tuntas (selesai).

5) Metode Stimulasi: dengar, lihat/coba, ulang, tuntas.

6) Sasaran Stimulasi: sensori-motorik, kognitif, komunikasi-bahasa, sosio-emosional, kemandirian, kreativitas, dan lain-lain.

7) Teknik Stimulasi: melalui suara, musik, gerakan, perabaan, bicara, menyanyi, membaca, mencocokkan, membandingkan, 
mengelompokkan, memecahkan masalah, mencoret, menggambar, merangkai, dan lainlain.

8) Pelaksanaan Stimulasi: setiap kali berinteraksi dengan anak; menyusui menidurkan, memandikan, ganti baju, di jalan, bermain, di dalam mobil, nonton TV, sebelum tidur, dan lain-lain.

\section{Penyelengaraan PAUD Nonformal}

a. Tidak kaku: jika masyarakat sudah ada keinginan (untuk memenuhi kebutuhannya) untuk mendirikan PAUD, jangan ditunda.

b. Kurikulum: menggunakan menu pembelajaran generic.

c. Sambil dimulai, pemerintah (pemilik PKS/PAUD) memantau, membina dan mengarahkan sampai akhirnya mendapatkan izin operasional.

d. Minimal enam bulan setelah program PAUD berjalan, diharapkan izin dari dinas pendidikan sudah didapat.

\section{Syarat mendapatkan izin, minimal:}

a. Ada orang yang bertanggung jawab sebagai penyelenggaraan/pengelola.

b. Ada anak yang akan dilayani.

c. Ada orang yang akan mendidik.

d. Ada tempat yang akan digunakan (tidak perlu bagus, yang penting aman bagi anak) da nada sarana untuk bermain.

e. Ada sumber dana yang jelas untuk kelangsungan program PAUD tersebut. 


\section{Strategi Mewujudkan PAUD Holistik dan Terintegrasi Yang Bermutu}

1. Penyusunan dan pengembangan "menu generic" (kurikulum PAUD nonformal); bekerja sama dengan konsorsium PAUD, perguruan tinggi dan pusat kurikulum, dan para praktisi PAUD.

2. Penyusunan/pengembangan standar PAUD nonformal (setelah ada BSNP); bekerja sama dengan BSNP.

3. Penyusunan/pengembangan berbagai acuan pembelajaran, modul (termasuk modul untuk orangtua/keluarga), dan pedoman-pedoman PAUD; bekerja sama dengan konsorsium PAUD, Forum PAUD, dan Himpaudi.

4. Penyelenggaraan pusat rujukan/pusat unggulan percontohan PAUD nonformal.

a) Bekerja sama dengan lembaga-lembaga internasional (seperti bank dunia, UNESCO, UNICEF, Plan Indonesia).

b) Bekerja sama dengan perguruan tinggi.

c) Bekerja sama dengan organisasi wanita, organisasi sosial kemasyarakatan dan LSM peduli PAUD.

d) Bekerja sama dengan konsorsium PAUD, FORUM PAUD, HIMPAUDI.

e) Bekerja sama dengan lembaga-lembaga PAUD yang telah mapan.

f) Bekerja sama dengan lembaga-lembaga keagamaan.

5. Menyelenggarakan program beasiswa, studi banding, magang, pelatihan, dan lain-lain di bidang PAUD nonformal bekerja sama dengan DITJEN PMPTK, pergurusn tinggi, lembaga-lembaga PAUD 
yang tellah mapan, LSM peduli PAUD, lembagalembaga internasional seperti Bank Dunia, UNICEF, UNISCO, Plan Indonesia.

6. Pengembangan model evaluasi PAUD nonformal.

7. Penguatan kelembagaan forum PAUD, konsorsium PAUD dan HIMPAUDI (melalui block grant dan pendampingan teknis). 


\section{BAB II}

\section{KONSEP DASAR PENDIDIKAN ANAK BERKEBUTUHAN KHUSUS (A Child Special Need)}

\section{A. Konsep Anak Berkebutuhan Khusus}

Pendidikan merupakan kebutuhan dasar setiap manusia untuk menjamin keberlangsungan hidupnya agar lebih bermartabat. Karena itu negara memiliki kewajiban untuk memberikan pelayanan pendidikan yang bermutu kepada setiap warganya tanpa terkecuali termasuk mereka yang memiliki perbedaan dalam kemampuan (difabel) seperti yang tertuang pada UUD 1945 pasal 31 (1). Namun sayangnya sistem pendidikan di Indonesia belum mengakomodasi keberagaman, sehingga menyebabkan munculnya segmentasi lembaga pendidikan yang berdasar pada perbedaan agama, etnis dan bahkan perbedaan kemampuan baik fisik maupun mental yang dimiliki oleh siswa. Jelas segmentasi lembaga pendidikan ini telah menghambat para siswa untuk dapat belajar menghormati realitas keberagaman dan masyarakat.

Seiring dengan berkembangnya tuntutan kelompok difabel dalam menyuarakan hak-haknya, maka kemudian muncul konsep pendidikan inklusi. Salah satu kesepakatan Internasional yang mendorong terwujudnya sistem pendidikan inklusi adalah Convention on the Rights of Person with Disabilities and Optional Protocol yang disahkan pada maret 2007. Pada pasal 24 dalam konvensi ini disebutkan bahwa setiap 
negara berkewajiban untuk menyelenggarakan sistem pendidikan inklusi di setiap tingkatan pendidikan. Adapun salah satu tujuannya adalah untuk mendorong terwujudnya partisipasi penuh difabel dalam kehidupan masyarakat. Namun dalam prakteknya sistem pendidikan inklusi di Indonesia masih menyisakan persoalan tarik ulur antara pihak pemerintah dan praktisi pendidikan, dalam hal ini para guru.

Anak berkebutuhan khusus merupakan amanah Allah SWT yang harus diperhatikan oleh penyelenggara pendidikan terutama pada satuan pendidik anak usia dini dan pemerintah. Peran pendidik pada lembaga usia dini sangat diperlukan, untuk itu diperlukan pemahaman yang sangat mendalam dalam proses pembelajaran usia dini terutama bagi anak berkebutuhan khusus. Terutama dalam pemberian layanan pembelajaran, metode, pendekatan, strategi dan langkah-langkah pembelajaran yang efektif, produktif dan menyenangkan.

Anak berkebutuhan khusus menurut Heward adalah anak dengan karakteristik khusus yang berbeda dengan anak pada umumnya tanpa selalu menunjukkan pada ketidakmampuan mental, emosional atau fisik. Yang termasuk kedalam ABK antara lain tunanetra, tunarunggu, tunagrahita, tunadaksa, tunalaras, kesulitan belajar, gangguan perilaku, anak berbakat, anak dengan gangguan kesehatan. Istilah lain bagi anak berkebutuhan khusus adalah anak luar biasa dan anak cacat.

Anak berkebutuhan khusus disebut juga dengan anak luar biasa, didefenisikan sebagai anak-anak yang berbeda dari anak-anak biasa dalam hal ciri-ciri mental, kemampuan sensorik, komunikasi, tingkah laku sosial, ataupun ciri-ciri fisik. Perbedaan ini telah mencapai tahap di mana anak-anak memerlukan modifikasi dalam 
aktifitas-aktifitas di sekolah ataupun pelayanan pendidikan khusus agar mereka mampu untuk berkembang dengan kapasitas maksimal.

Menurut Kirk (1989), anak-anak hanya dianggap sebagai anak-anak luar biasa apabila memiliki kebutuhan untuk menyesuaikan program pendidikan. Ini akibat dari keadaan mereka tersebut menyebabkan mereka tidak dapat menerima pelajaran dengan cara biasa, dan menempatkan mereka dalam barisan depan kelas hanya akan membuat mereka bosan. Ini juga menunjukkan bahwa anak-anak dengan IQ yang tinggi (gifted) juga tergolong anak-anak luar biasa. ${ }^{18}$

Anak berkebutuhan khusus (a child special need) meruapakan anak yang terlahir ataupun tumbuh dan berkembang dengan berbagai kekurangan, baik fisik, mental maupun intelegensi. ${ }^{19}$ Salah satu kelompok yang paling tereksklusi dalam memperoleh pendidikan adalah siswa penyandang cacat.

Masyarakat awam sering kali beranggapan bahwa anak-anak berkebutuhan khusus terbatas pada anakanak yang memiliki cacat fisik sehingga dianggap sebagai suatu hal yang biasa karena mudah untuk dilihat dan dilakukan diagnosis. Pada kenyataannya, anak-anak berkebutuhan khusus terutama dengan kesulitan sering kali tersembunyi diantara anak-anak lainnya dan sangat sulit untuk dilakukan diagnosa.

Suran dan Rizzo dalam mangunsong mendefenisikan bahwa anak yang memiliki kebutuhan khusus sebagai

18 Jamila K.A., Muhammad, 2008, Special Education for special children (Panduan Pendidikan Khusus Anak-anak dengan ketunaan dan learning disabilities, cet.I (Jakarta:Hikmah), h.36-37

19 Hamzah B.Uno dan Masri Kuadrat, 2009, Mengelola kecerdasan dalam pembelajaran:sebuah konsep pembelajaran berbasis kecerdasan, cet, I (jakarta: Bumi Aksara), h.2 
anak yang secara signifikan berbeda dalam berbagai dimensi yang penting dari fungsi kemanusiaannya. Mereka yang secara fisik, psikologis, kognitif, atau sosial terhambat dalam mencapai tujuan-tujuan/kebutuhan dan potensinya secara maksimal, meliputi mereka yang tuli, buta, mempunyai gangguan bicara, cacat tubuh, retardasi mental, gangguan emosional. Juga anak yang berbakat dengan intelegensi tinggi, dapat dikategorikan sebagai anak khusus/luar biasa karena memerlukan penanganan terlatih dan tenaga profesional.

Mangunsong juga mendefenisikan anak yang tergolong luar biasa atau berkebutuhan khusus sebagai anak yang menyimpang dari rata-rata anak normal dalam hal:ciri-ciri mental, kemampuan-kemampuan sensorik, fisik, dan neuromuscular, perilaku sosial dan emosional, kemampuan berkomunikasi, maupun kombinasindua atau tiga dari hal-hal diatas; sejauh ia memerlukan modifikasi dari tugas-tugas sekolah, metode belajar atau pelayanan terkait lainnya, yang ditujukan untuk mengembangkan potensi atau kapasitasnya secara maksimal.20

Adapun ciri-ciri anak yang mengalami gangguan perkembangan sebagai berikut: ${ }^{21}$

1. Terlalu pasif

2. Terlalu cengeng

3. Untuk digendong, karena badannya terlalu kaku dan bayi sering membuang badannya ke belakang

4. Sering muntah

5. Menangis bila tengkurap

20Mangunsong F, 2009, Psikologi dan Pendidikan anak berkebutuhan khusus, Jilid I ( Depok: Lembaga sarana pengukuran dan pendidikan psikologi UI), h.

21 Ratih Zimmer Gandasetiawan, 2011, Mendesain karakter anak melalui sensimotor, cet.2, (Jakarta: Gunung Mulia), h.56 
6. Jari jempol selalu masuk dalam genggaman

7. Bayi sudah berusia lebih dari empat bulan, tetapi tidak dapat mengangkat kepala sendiri saat tengkurap, sulit untuk berguling

8. Menangis bila diayun

9. Sulit menelan makanan

10. Tidak mampu memperoses makanan yang berada dimulut karena langsung ditelan oleh bayi sehingga selalu harus mengkonsumsi makanan lembut

11. Senang menyimpan makanan dimulut dalam waktu yang cukup lama

12. Tidak mengoceh juga terlihat tidak ceria.

\section{B. Memahami karakteristik $\mathbf{A B K}^{22}$}

Anak berkebutuhan khusus terbagi dua, yakni:

1. Potensi CIBI; (a) cerdas istimewa, (b) bakat istimewa-berhak mendapatkan pendidikan khusus.

a. Cerdas istimewa

Fisik

Perilaku
: (mungkin) tidak ada

: berfikir cepat, kreatif, mandiri, tanggung jawab terhadap tugas, prestasinya mengangumkan, atau memiliki bakat yang menonjol.

Keluhan

b. Berbakat (CIBI)

Seseorng disebut istimewa dan/atau bakat istimewa apabila setelah diukur dengan menggunakan tes kecerdasan baku menghasilkan skor IQ di atas 110 (superior, gifted, talentet), kreatifitas dan task commitment di atas rata-rata. Seseorang disebut memiliki bakat istimewa

22 Mukhtar Latif dkk, 2014, Orientasi Baru Pendidikan anak usia dini:Teori dan Aplikasi, (Jakarta: Kencana Prendamedia Group), h. 284 
apabila bakat tersebut sangat menonjol dalam bidang akademik tertentu, olahraga, seni dan/atau kepemimpinan melebihi tingkat perkembangan usia teman sebaya.

2. Berkelainan: (1) fisik, (2) mental-intelektual, (3) emosi dan sosial-berhak mendapatkan pendidikan khusus.

Menurut Kauffman dan Hallahan, anak berkebutuhan khusus yang paling banyak mendapat perhatian guru, antara lain sebagai berikut:

A. Tunagrahita (mental reterdation) atau disebut sebagai anak dengan rendahnya perkembangan (child with development impairment)

B. Kesulitan belajar (learning disabbilities atau anak yang berpotensi rendah (specific learning disability)

C. Hyperactive (attention deficit disorder with hyperactive)

D. Tunalaras (emotional or behavioral disorder)

E. Tunarungu wicara (communication disorder and deafness)

F. Tunanetra (partially seing and legal blind)

G. Anak autistik (autistic children)

H. Tunadaksa (physical disability)

I. Tunaganda (double handicapped)

J. Anak berbakat (giftedness and special talents)

\section{Dasar Hukum}

1. Komitmen Jomtien Thailand (1990), Pendidikan untuk semua, sejak lahir sampai ajal.

2. Deklarasi Dakkar (2000) " memperluas dan memperbaiki keseluruhan perawatan dan 
pendidikan anak usia dini secara komprehensif terutama yang sangat rawan dan terlantar."

3. Pada tahun 1975 Undang-undang publik ( law Public) 94-142 direvisi yang menghendaki setiap negara untuk menyediakan akses program pendidikan gratis dalam sistem sekolah umum pada anak-anak istimewa yang berumur 3-18 tahun, hak ini dikembangkan untuk anak-anak berkebutuhan khusus dalam pembentukan Public Law yang menitikberatkan pada bayi dan anak-anak. Peruntukan tersebut memberi hak yang jelas kepada orang tua dalam membentuk dan membantu pelaksanaan ataupun program pendidikan anakanak istimewa mereka. ${ }^{23}$

4. Pasal 131 ayat (1) : pemerintah provinsi menyelenggarakan paling sedikit satu satuan pendidikan khusus untuk setiap jenis kelainan dan jenjang pendidikan sebagai model sesuai kebutuhan peserta didik.

5. Pasal 133 ayat (1) : Satuan pendidikan khusus formal bagi peserta didik berkelainan untuk pendidikan anak usia dini berbentuk taman kanakkanak luar biasa atau sebutan lain untuk satuan pendidikan sejenis dan sederajat.

6. Berdasarkan akta pendidikan 1996, peraturan pendidikan khusus di Malaysia....suatu pendidikan inklusif untuk murid-murid berkebutuhan khusus dimana mereka dapat bergabung dalam kelas umum bersama-sama dengan murid biasa. Selain itu akta pendidikan 1996 mengatakan bahwa pendidikan khusus di sekolah negeri dan bantuan pemerintah harus diikuti oleh anak-anak berkebutuhan khusus

${ }^{23}$ Jamila K.Muhammad, Op,cit 
yang dapat dididik dengan syarat; jika dia mampu mengurus diri sendiri tanpa bergantung pada bantuan orang lain dan disahkan oleh suatu kelompok panel yang terdiri dari para ahli terapi, pihak menteri pendidikan, dan pihak dari lembaga sosial masyarakat dan berupaya dalam pelaksanaan program pendidikan nasional.

7. Pasal 129 Ayat (1) Pendidikan khusus bagi peserta didik berkelainan berfungsi memberikan pelayanan pendidikan bagi peserta didik yang memiliki kesulitan dalam mengikuti proses pembelajaran, karena kelainan fisik, emosional, mental, intelektual, dan/atau sosial. 


\section{BAB III}

\section{FAKTOR PENYEBAB DAN DAMPAK KELAINAN PADA ANAK BERKEBUTUHAN KHUSUS}

\section{A. Faktor-faktor Penyebab Kelainan pada Anak Berkebutuhan Khusus}

Tidak ada faktor penyebab tunggal yang mengakibatkan anak berkebutuhan khusus. Berbagai macam penyebab kelainan yang mengakibatkan terjadinya penyimpangan atau kelainan sehingga mereka dikelompokkan menjadi anak luar biasa (ALB).

\section{Faktor penyebab internal}

Penyebab faktor internal adalah berbagai penyebab yang terjadi berasal dari dalam diri anak itu sendiri. Misalnya anak dilahirkan dengan membawa kecacatan / kelainan atau penyimpangan.

\section{Faktor penyebab eksternal}

Penyebab faktor eksternal adalah berbagai penyebab yang terjadi diluar diri anak itu sendiri, misalnya terjatuh atau pengaruh lingkungan yang kurang menunjang.

\section{Penyebab ditinjau dari waktu terjadinya gangguan}

a. Faktor penyebab yang terjadi saat prenatal (dalam kandungan), meliputi segala penyebab yang terjadi pada saat sebelum dilahirkan (dalam kandungan ibu), sebab-sebab yang terjadi pada saat prenatal meliputi : 
1) Anoxia (kekurangan oxigen).

Pada tri semester pertama bayi sangat sensitif terhadap kekurangan okxigen, yang sangat berpengaruh terhadap peredaran darah pada janin. Gangguan ini terjadi diakibatkan karena terjadinya pendarahan (blooding), lilitan placenta pada saluran nafas, dan tekanan yang terjadi saat ibu terjatuh saat kehamilan.

2) Maternal infection diseases

Yaitu infeksi yang terjadi akibat penyakit atau kelainan yang dialami ibu disaat hamil, misalnya Campak (Rubella), Infeksi akibat toxoplasma.

\section{b. Faktor penyebab yang terjadi saat natal}

Meliputi segala penyebab yang terjadi pada saat lahir atau partus seperti: Anoxia atau asphyxia yaitu kekurangan oksigen pada saat lahir, akibat dari tali pusat yang melilit, pinggul ibu yang sempit, Kesalahan obat, disaat ibu hamil menggunakan obatobatan dengan dosis yang tinggi sehingga akan menimbulkan proses pernafasan, suhu badan menurun, yang berakibat kerusakan otak pada sang bayi, dan trauma. Hal ini terjadi akibat partus yang sulit misalnya : Kepala yang melebihi proporsi atau ukuran kepala yang lebih besar, Penggunaan vacum extractic, Waktu partus terlalu lama, bayi terhenti di cervic, Letak bayi sunsang, Perubahan yang mendadak pada kelahiran caesar, Prematuritis, kelahiran yang tidak cukup waktu dan berat badan, meningritis purulenta, peradangan yang terjadi pada saat selaput otak yang menimbulkan perlengketan dan rusaknya sel otak. 


\section{c. Faktor penyebab yang terjadi saat postnatal}

Meliputi segala penyebab yang terjadi setelah lahir sampai dengan usia 3 tahun. Sebab terjadinya kelainan pada saat postnatal meliputi :

1) Trauma (terjadi kecelakaan, geger otak/brain damage).

2) Infeksi pada otak misal, meningitis (sekaput otak), encephalitis (sel-sel otak), meningoencephalitis.

3) Neoplasma misalnya tumor dan kanker otak.

4) Intoxikasi (keracunan makanan dan obatobatan)

5) Anoxia, asphyxia

6) Gangguan pembuluh darah ke otak.

\section{B. Implikasi Terjadinya Anak Berkebutuhan Khusus}

Implikasi terjadinya anak berkebutuhan khusus atau dalam bahasa inggris disebut dengan Children with Special Needs. Akibat terjadinya berkebutuhan khusus sebagai suatu keadaan pada individu dengan kondisi mental yang lemah termanifestasikan pada bentuk keterlambatan dan ketidakseimbangan di dalam segala aspek. Tantangan membimbing berkebutuhan khusus tersebut sebagai wujud dari hambatan yang dimiliki berkebutuhan khusus. Hambatan itu adalah internalisasi rangsangan lingkungan berakibat anak berkebutuhan khusus tidak mampu memenuhi tuntutan lingkungan secara fisiologis, psikologis dan sosiologis. Berkebutuhan khusus mengalami kesulitan dalam memenuhi tuntutan lingkungan tersebut sebagai dampak dari keadaan kebutuhan khusunya yang berakibat juga pada kondisi sosial psikologis anak berkebutuhan khusus. 
Berikut secara rinci diuraikan sebagai berikut:

\section{Dampak Fisiologis}

Dampak fisiologis, terutama pada anak-anak yang mengalami kelainan yang berkaitan dengan fisik termasuk sensori-motor terlihat pada keadaan fisik penyandang berkebutuhan khusus kurang mampu mengkoordinasi geraknya, bahkan pada berkebutuhan khusus taraf berat dan sangat berat baru mampu berjalan di usia lima tahun atau ada yang tidak mampu berjalan sama sekali. Tanda keadaan fisik penyandang berkebutuhan khusus yang kurang mampu mengkoordinasi gerak antara lain: kurang mampu koordinasi sensori motor, melakukan gerak yang tepat dan terarah, serta menjaga kesehatan.

\section{Dampak Psikologis}

Dampak psikologis timbul berkaitan dengan kemampuan jiwa lainnya, karena keadaan mental yang labil akan menghambat proses kejiwaan dalam tanggapannya terhadap tuntutan lingkungan. Kekurangan kemampuan dalam penyesuaian diri yang diakibatkan adanya ketidaksempurnaan individu, akibat dari rendahnya "self esteem" dan dimungkinkan adanya kesalahan dalam pengarahan diri (self direction).

\section{Dampak Sosiologis}

Dampak sosiologis timbul karena hubungannya dengan kelompok atau individu di sekitarnya, terutama keluarga dan saudara-saudaranya. Kehadiran anak berkebutuhan khusus di keluarga menyebabkan berbagai perubahan dalam keluarga. Keluarga sebagai suatu unit sosial di masyarakat dengan kehadiran anak berkebutuhan khusus merupakan musibah, kesedihan, dan beban yang berat. Kondisi itu termanifestasi dengan reaksi yang 
bermacam-macam, seperti : kecewa, shock, marah, depresi, rasa bersalah dan bingung. Reaksi yang beraneka ini dapat mempengaruhi hubungan antara anggota keluarga yang selamanya tidak akan kembali seperti semula.

Pada umumnya, ibu yang mengalami trauma paling berat dan mendapatkan peran yang terkekang dengan kehadiran anak berkebutuhan khusus. Peran harus memelihara anak berkebutuhan khusus dibutuhkan banyak waktu, sehingga banyak tugas lain semakin berkurang. Dengan tumbuhnya anak berkebutuhan khusus yang semakin besar, muncullah dilemma pada ibu yang fungsinya sebagai penjaga atau pemelihara dan tugasnya untuk menumbuhkan kemandirian anak. Semua masalah di keluarga tersebut merupakan dampak sosiologis yang harus ditanggung oleh keluarga.

Anak berkebutuhan khusus yang kurang mampu menyesuaikan diri dengan tuntutan lingkungan sosialnya, dapat menimbulkan respon yang negatif dari lingkungan sosial anak berkebutuhan khusus. Hal ini berdampak anak dijauhi atau ditolak oleh lingkungan sosial, dan dalam berkomunikasi akan terjadi jurang pemisah (communication gap) antara anak berkebutuhan khusus dengan orang-orang di lingkungannya. Jurang pemisah dalam hal berkomunikasi dapat terjadi karena orang di lingkungannya menyampaikan pesan verbal yang tidak sesuai dengan kemampuan atau daya tangkap anak berkebutuhan khusus. "Communication gap" ini merupakan dampak yang menimbulkan salah suai pada anak berkebutuhan khusus. 


\section{Masalah-Masalah Yang Dihadapi Anak Berkebutuhan Khusus}

Dampak keberkebutuhan khusus dari tiga dimensi tersebut menyebabkan pengaruh yang cukup berarti dalam kehidupan mereka. Keterbatasan dan daya kemampuan yang mereka miliki menimbulkan munculnya berbagai masalah. Masalah yang mereka hadapi relatif berbeda-beda, walaupun ada kesamaan yang dirasakan oleh mereka ini sebagai dampak keberkebutuhan kekhususan, dan yang ada kesamaan dirasakan mereka (Amin, 1995: 41-51) meliputi:

\section{Masalah kesulitan dalam kehidupan sehari-hari}

Masalah ini berkaitan dengan kesehatan dan pemeliharaan diri sendiri. Kondisi keterbatasan mereka banyak yang mengalami kesulitan dalam kehidupan seharihari terutama pada berkebutuhan khusus kategori berat dan sangat berat. Keadaan itu diharapkan dalam program penanganan memprioritaskan bimbingan dan latihan keterampilan aktifitas kehidupan sehari-hari terutama memelihara diri sendiri, seperti: cara makan, menggosok gigi, memakai baju, memasang sepatu, serta pekerjaan rumah tangga yang sangat sederhana.

\section{Masalah penyesuaian diri}

Kemampuan penyesuaian diri dengan lingkungan dipengaruhi beberapa faktor salah satunya kecerdasan. Kecerdasan yang rendah berakibat hambatan penyesuaian diri, dan pada anak berkebutuhan khusus. Kondisi itu menimbulkan kecenderungan diisolir oleh keluarga maupun masyarakat. Kecenderungan terisolasi pada mereka mengakibatkan pembentukan pribadinya tidak layak, untuk itu dalam program penanganan pada mereka 
perlu menyarankan kepada keluarga supaya tidak mengisolir.

\section{Masalah penyaluran ke tempat kerja}

Keterbatasan pada anak berkebutuhan khusus merupakan problem di dalam mendapatkan pekerjaan. Masalah ini perlu diprioritaskan dalam program penanganan untuk menyiapkan anak berkebutuhan khusus dengan berbagai program keterampilan yang dapat digunakan untuk mencari nafkah atau bekerja. Lembaga penanganan anak berkebutuhan khusus perlu juga memprogramkan penyaluran kerjanya atau membentuk bengkel kerja yang terlindung (sheltered work shop).

\section{Masalah kesulitan belajar}

Keterbatasan kemampuan fisiologik dari anak berkebutuhan khusus mengakibatkan kesulitan mencapai prestasi belajar bidang akademik. Kondisi ini perlu diperhatikan bahwa program penanganan diusahakan dapat memenuhi kebutuhan anak untuk mencapai prestasi belajar. Dalam pembelajaran bidang akademik diusahakan materi dan metode, serta equipment yang sesuai dengan kondisi mereka.

\section{Masalah gangguan kepribadian dan emosi}

Keterbatasan pada fisiologis anak berkebutuhan khusus menyebabkan keseimbangan pribadinya kurang stabil. Kondisi yang demikian itu dapat dilihat pada penampilan tingkah lakunya sehari-hari, misalnya: berdiam diri berjam-jam lamanya, gerakan yang hiperaktif, mudah 
marah, mudah tersinggung, suka mengganggu orang lain di sekitarnya, bahkan tindakan merusak (destruktif).

\section{Masalah pemanfaatan waktu luang}

Anak berkebutuhan khusus dalam tingkah lakunya sering menampilkan tingkah laku nakal dan mengganggu ketenangan lingkungannya, hal ini terjadi karena anak berkebutuhan khusus tidak mampu berinisiatif yang dipandang layak oleh lingkungan. Mereka tidak mampu menggunakan waktu untuk inisiatif kegiatan yang terarah jika tidak ada yang mengarahkan. Bagi yang pasif cenderung suka berdiam diri atau menjauhkan diri dari keramaian. Kondisi-kondisi yang terjadi pada berkebutuhan khusus itu perlu diperhatikan dalam program penanganan untuk memberi kegiatan saat mereka mempunyai waktu luang. Kegiatan yang terarah saat waktu luang untuk menghindari efek negatif yang dilakukan olehnya karena kegiatannya tidak membahayakan dan tidak mengganggu lingkungan. Kegiatan yang terarah pada waktu luang merupakan tenggung jawab bersama antara sekolah, pengasuh, dan orang tua. Tanggung jawab bersama ini mutlak dilakukan karena mereka saat berada di manapun kegiatannya harus diarahkan. 


\section{BAB IV}

\section{KLASIFIKASI DAN KARAKTERISTIK ANAK BERKEBUTUHAN KHUSUS}

Menurut Kauffman dan Hallahan, anak berkebutuhan khusus yang paling banyak mendapat perhatian guru, antara lain sebagai berikut:

A. Tunagrahita (mental reterdation) atau disebut sebagai anak dengan rendahnya perkembangan (child with development impairment)

B. Kesulitan belajar (learning disabbilities atau anak yang berpotensi rendah (specific learning disability)

C. Hyperactive (attention deficit disorder with hyperactive)

D. Tunalaras (emotional or behavioral disorder)

E. Tunarungu wicara (communication disorder and deafness)

F. Tunanetra (partially seing and legal blind)

G. Anak autistik (autistic children)

H. Tunadaksa (physical disability)

I. Tunaganda (double handicapped)

J. Anak berbakat (giftedness and special talents) Berikut diuraikan secara terperinci masin-masing kekhususan yang dialami anak antara lain: 


\section{A. Kesulitan Belajar (Learning Disabilities) atau anak yang berprestasi rendah (Spesisific Learning Disability)}

Individu mengalami pada satu atau lebih pada kemampuan dasar psikologis umumnya, khususnya penggunaan bahasa, bebicara dan menulis. Gangguan tersebut selanjutnya mempengaruhi kemampuan berpikir, membaca, berhitung, atau kemampuan berbicara. Penyebabnya antara lain gangguan persepsi, brain injury disfungsi minimal otak, disleksia, dan afasia perkembangan. Individu kesulitan belajar memiliki IQ rata-rata di atas ratarata, mengalami gangguan motorik, gangguan koordinasi gerak, gangguan orientasi arah dan ruang, serta mengalami keterlambatan perkembangan konsep.

\section{B. Tunarungu Wicara (Communcation Disorder and Deafness)}

Tunarungu adalah individu yang memiliki habatan dalam pendengaran permanen maupun temporer (tidak permanen). Tunarungu diklasifikasikan berdasarkan tingkat gangguan pendengaran, yaitu gangguan pendengaran sangat ringan (27-40 dB), gangguan pendengaran ringan (41-55 dB), gangguan pendengaran sedang (56-70 dB), gangguan pendengaran berat (71-90 $\mathrm{dB}$ ), gangguan pendengaran ekstrem/tuli (di atas $91 \mathrm{~dB}$ ).

Hambatan pendengaran dalam individu tunarungu berakibat terjadinya hambatan dalam berbicara. Cara berkomunikasi dengan individu tunarungu menggunakan bahasa isyarat melalui abjad jari yang dipatenkan secara internasional. Untuk berkomunikasi dengan bahasa isyarat masih berbeda-beda setiap wwarga Negara. Saat ini, dibeberapa SLB bagian B tengah mengembangkan komunikasi total, yaitu cara berkomunikasi dengan 
melibatkan bahwa verbal, bahasa isyarat, dan bahasa tubuh. Individu tunarungu cenderung kesulitan dalam memahami konsep dari sesuatu yang abstrak.

\section{Hiperactive (Attention Deficit Disorder with Hyperactive)}

Hiperaktif bukanlah merupakan penyakit melainkan suatu gejala atau sympstom (Batshaw dan Parret, 1986: 261). Gejala-gejala "kelainan" dari anak hiperaktif antara lain in-atensi, hiperativitas, dan implusivitas. Anak-anak hiperatktif memerlukan suatu layanan dengan cara pemberian intervensi dengan terapi farmakologi dikombinasikan dengan terapi perilaku (behavior modification). Jika anak hiperaktif tidak mendapatkan layanan terapi, maka yang bersangkutan dikemudian hari akan berkembang kearah "kriminal". Suka mengutil barang, mencuri, mencoba-coba narkoba, merusak property, dan cenderung berkembang kea rah problem yang lain, yaitu conduct disosder (CD) (Solek, 20014:5).

Ciri yang paling mudah dikenal bagi anak hiperaktif adalah anak akan selalu bergerak dari suatu tempat ke tempat lain, selain itu yang bersangkutan sangat jarang untuk berdiam selama kurang lebih 5-10 menit guna melakukan suatu tugas, karenanya di sekolah anak hiperaktif mendapatkan kesulitan untuk berkonsentrasi dalam tugas-tugas kerjanya. Ia selalu mudah bingung atau kacau pikirannya, tidak suka memerhatikan perintah atau penjelasan dari gurunya, dan selalu tidak berhasil dalam melakukan tugas-tugas pekerjaan sekolah, sangat sedikit kemampuan mengeja huruf, tidak mampu untuk meniru huruf-huruf (Raport \& Ismon, 1984 dalam Betshaw \& Perret, 1986:263).

Ciri-ciri: 
a. Selalu berrjalan-jalan memutari ruang kelas dan tidak mau diam.

b. Sering mengganggu teman-teman di kelasnya.

c. Seka berpindah-pindah dari suatu kegiatan ke kegiatan lainnya dan sangat jarang untuk tinggal diam menyelesaikan tugas sekolah, paling lama bias tinggal diam di tempat duduknya sekitar 5-10 menit.

d. Mempunyai kesulitan untuk berkonsentrasi dalam tugas-tugas sekolah.

e. Sangat mudah berprilaku untuk mengacau atau mengganggu.

f. Kurang memberi perhatian orang lain berbicara.

g. Selalu mengalami kegagalan dalam melaksanakan tugas-tugas di sekolah.

h. Sulit mengikuti perintah atau suruhan lebih dari satu pada saat bersamaan.

i. Mempunyai masalah belajar hampi di seluruh bidang studi.

j. Tidak mampu menulis surat, mengeja huruf, dan berkesulitan dalam surat-menyurat.

k. Sering gagal di sekolah kerena in-atensi dan masalag belajar karena persepsi visual dan audiotori yang lemah.

l. Karena sering mengikuti kata hati (impulsiveness), merkea sering kecelakaan dan luka (Raport \& Ismon, 1984 dalam Betshaw \& Perret, 1986:263).

\section{Tunanetra (Partially Seing and Legally Blind)}

Tunanetra adalag individu yang memiliki hambatan dalam penglihatan. Tunanetra dapat dilasifikasikan ke dalam dua golongan yaitu buta total (blind) dan low vision. Koufman dan Hallahan mendefinisikan makna tunanetra sebagi individu yang memiliki lemah penglihatan atau 
akurasi penglihatan $6 / 60$ setelah dikoreksi atau tidak lagi memiliki penglihatan. Karena tunanetra memiliki keterbatasan dalam indra penglihatan, maka proses pembelajaran menekankan pada alat indra yang lain, yaitu indra peraba dan indra pendengaran. Oleh karena itu, prinsip yang harus diperhatikan dalam memberikan pengajaran kepada individu tunanetra adalah media yang digunakan harus bersifat faktual dan bersuara. Sebagai contoh adalah penggunaan huruf Braille, gambar timbul, benda model, dan benda nyata. Adapun media bersuara adalah tape recorder dan peranti lunak (softwere) JAWS. Di sekolah SLB bagian A, aktivitas tunanetra dibantu dengan pelajaran mengenai orietasi dan mobilitas. Antara lain mempelajari cara mengetahui tempat dan arah serta menggunakan tongkat putih (tongkat khusus tunanetra yang dibuat dari almunium).

\section{E. Tunalaras (Emotional or Behavioral Disorder)}

Definisi berkaitan dengan tunalaras atau emotionally handicapped atau behavioral disorder sekarang lebih terarahkan berdasarkan defenisi dari Eli M. Bower (1981) yang menyatakan bahwa anak dengan hambatan emosional kelainan perilaku, apabila ia menunjukkan adanya satu atau lebih dari komponen berikut ini.

a. Tidak mampu belajar bukan disebabkan karena factor intelektual, sensori atau kesehatan.

b. Tidak mampu untuk melakukan hubungan baik dengan teman atau guru.

c. Bertingkah laku atau berperasaan tidak pada tempatnya.

d. Secara umum, mereak selalu dalam keadaan persavive dan tidak menggembirakan atau depresi. 
e. Bertendensi ke arah symptoms fisik, seperti: merasa sakit atau ketakutan berkaitan dengan atau orang atau permasalahan di sekolah.

Berdasarkan definisi dari Bower tersebut, masalah hambatan dalam pembelajaran merupakan karakteristik pertama dan merupakan aspekyang signifikan di sekolah. Dari defenisi hambatan emosional tercatat dalam Peraturan Pemerintah Amerika (Public Low, 94-142 Secaltion 121 a.5), antara lain:

1) Mempunyai kondisi atau lebih dari komponen Bower akan berpengaruh terhadap kinerja pendidikan untuk periode waktu yang panjang.

2) Secara pasti bahwa ketidakmampuan belajar bukan disebabkan karena factor-faktor berkaitan dengan kemampuan intelektual, sensori, dan kesehatannya.

3) Tidak mampu untuk melakukan kerjasama memuaskan dengan teman-teman dan gurunya.

4) Mempunyai tipe perilaku yang tidak pada tempatnya atau perasaan yang tidak umum dengan lingkungannya.

5) Mempunyai perasaan tidak gembira atau suka depresi.

6) Bertendesi kea rah symptoms fisik. Misalnya, perasaan takut terhadap perorangan atau permasalah yang ada di sekolah.

7) Istilah tersebut kepada mereka yang menyandang schizopronic atau autistic. Tapi tidak menyangkut kepada mereka yang tidak mampu beradaptasi secara sosial. 


\section{F. Tunarungu Wicara (Communication Disorder abd Deafetess)}

Ciri-ciri perkembangan bahasa dan komunukasi antara lain:

a. Kurang memperhatikan saat guru memberikan pelajaran di kelas.

b. Sumber bunyi, sering kali ia meminta pengulangan penjelasan guru saat di kelas.

c. Mempunyai kesulitan untuk mengikuti petunjuk secara lisan.

d. Keengganan untuk berpastisipasi secara social, mereka mendapatkan kesulitan untuk berpartisipasi secara oral dan dimungkinkan karena hambatan pendengarannya.

e. Adanya ketergantungan terhadap petunjuk atau instruksi saat berada di kelas.

f. Mengalami hambatan dalam perkembangan bahasa dan bicara.

g. Perkembangan intelektual peserta didik tunarungu wcara terganggu.

h. Mempunyai kemampuan akademik yang rendah, khususnya dalam membaca.

\section{G. Karakteristik Anak Autistik (Autustic Child)}

Autistik dipahami sebagai gangguan perkembangan neurobiologis yang berat sehingga gangguan tersebut mempengaruhi bagaimana anak belajar, berkomunikasi, keberadaan anak dalam lingkungan dan hubungan dengan orang lain. ${ }^{24}$

24Joko Yuwono, 2009, Memahami Anak Autistik (Kajian Teoritik dan Empirik), (Bandung: Alfabeta), h.25 
Autistic syndrome merupakan kelainan yang disebabkan hambatan pada ketidakmampuan bebrbahsa yang diakibarkan oleh kerusakan pada otak. Gejala-gejala penyandang autism menurut Delay \& Deinaker (1952), dan Marholin \& Philips (1976) antara lain:

a. Senang tidur bermalas-malasan atau duduk menyendiri dengan tampang acuh, muka pucat, mata sayu, dan selalu memandang ke bawah.

b. Selalu diam sepanjang waktu.

c. Jika ada pertanyaan terhadapnya, jawabannya sangat pelan dengan nada monoton, kemudian dengan suara yang aneh ia akan mengucapkan atau menceritakan dirinya dengan beberapa kata, kemudian diam menyendiri lagi.

d. Tidak pernah bertanya, tidak menunjukkan rasa takut, tidak punya keinginan yang bermacam-macam, serta tidak menyenangi sekelilingnya.

e. Tidak tampak ceria.

f. Tidak perduli terhadap lingkungannya, kecuali pada benda yang disukainya, misalnya boneka.

Secara umum anak autistil mengalami kelainan dalam berbicara, disamping mengalami gangguan pada kemampuan intelektual serta fungsi saraf. Hal tersebut dapat terlihat dengan adanya keganjilan perilaku dan ketidakmampuan berinteraksi dengan lingkungan masyarakat sekitarnya. Perincian tentang kelainan anak autis sebagai berikut:

a. Kelainan berbicara. Keterlambatan serta penyumpangan dalam berbicara menyebabkan anak sutistik sukar berkomunikasi serta tidak mempu memahami percakapan orang lain. Sebagai anak autis tampaknya seperti bisu (mute) dan bahkan tidak mampu menggunakan isyarat gerak saat 
berkomunikasi dengan orang lain, sehingga penggunaan bahasa isyarat tidak dapat dilakukan. Suara yang keluar biasanya bernada tinggi terdengar aneh, berkecenderungan meniru, terkesan menghafal kata-kata tetapi sesungguhnya mereka tidak mampu berkomunikasi. Walaupun pengucapan kata cukup baik, namun banyak mempunyai hambatan saat mengungkapkan perasaan diri melalui bahasa lisan. Dengan demikian, sepertinya anak autistic memahami kata-kata disebabkan adanya kelainan pada syaraf otak.

b. Kelainan fungsi syaraf inetelektual. Umumnya anak autistic mengalami keterbelakangan mental. Kebanyakan mempunyai skor IQ 50. Mereka tergolong tidak mempunyai kecakapan untuk memahami bendabenda abstrak atau simbolik. Namun di sisi lain mereka mampu memcahkan teka teki yang rumit dan mampu mengalihkan suatu bilangan. Walaupun ia mampu membaca koran dengan penuh perasaan, namu ia tidak mengerti bacaan yang ada pada koran tersebut.

c. Perilaku anak ganjil. Anak autistic akan mudah sekali marah bila ada perubahan yang dilakukan pada situasi atau lingkungan tempat ia berada, walau sekecil apapun. Mereka sangat tergantung pada suatu yang khas bagi dirinya. Misalanya, selalu membawa barangbarang yang paling disenangi sewaktu bepergian kemanapun semacam selimut, atau karet gelang. Sering kali anak autistic menunjukkan sikap yang berulang-ulang. Misalnya, suka menggerak-gerakkka badannya dan bergoyang-goyang saat ia sedang dudu di kursi, terkadang secara tiba-tiba berteriak atau tertawa tanpa sebab yang jelas. Bahkan sering melakukan tindakan untuk menyakiti dirinya sendiri. 
Misalnya, membenturkan kepala atau mengorek matanya. Saat makan tiba ia sering menolak makanan yang disodorkan, ia hanya memakan satu jenis makanan dan dimakan hanya sedikit saja.

d. Interaksi sosial. Anak autistic kurng suka bergaul dan sangat terisolasi dari lingkungan hidupnya, terlihat kurang ceria, tidak pernah menaruh perhatian atau keinginan untuk menghargai perasaan orang lain, dan suka menghindar dengan orang di sekitarnya sekalipun saudaranya sendiri. Dengan kata lain kehidupan social anak autustik selalu aneh dan terlihat seperti orang yang selalu sakit.

\section{H. Karakteristik Anak Tunadaksa atau Anak dengan Hendaya Fisik Motorik (Physical Disability)}

Pada dasarnya kelainan pada peserta didik tunadaksa dikelompokkan menjadi dua bagian besar, yaitu kelainan pada system serebral (cerebral system) dan kelainan pada system otot dan rangka (musuculoskletal system). Peserta didik tunadaksa mayoritas mayoritas memiliki kecacatan fisik sehingga mengalami gangguan pada keoordinasi gerak, persepsi, dan kognisi, di samping adanya kerusakan saraf tertentu. Dengan demikian, dalam memberikan layanan di sekolah memerlukan modifikasi dan adaptasi yang diklasifikasikan dalam tiga kategori umum, yaitu kerusakan saraf, kerusakan tulang, dan anak dengan gangguan kesehatan lainnya. Keruskan saraf disebabkan kerana pertumbuhan sel saraf yang kurang atau adanya luka pada system saraf pusat. Kelainan saraf utama menyebabkan adanya cerebral palsy, epilepsy, spinabifidam dan kerusakan otak lainnya.

Cerebral palsy merupakan kelainan diakibatkan adanya kesulitan gerak berasal dari fungsi otak. Ada juga 
kelainan gerak atau palsy yang diakibatkan oleh kerusakan otot (dystrophy muscular). Karena adanya disfungsi otak, maka peserta didik penyandang cerebral palsy mempunyai kelainan dalam bahasa, bicara, menulis, emosi, belajr, dan gangguan psikologis. Cerebral palsy dapat didefinisikan sebagai "laterasi perpindahan yang abnormal atau fungsi otal yang muncul karena kerusakan, luka, atau penyakit pada jaringan saraf yang terkandung dalam rongga tengkorak."

Definisi lainnya menyatakan bahwa "Cerebral palsy merupakan kondisi yang bersifat klinis yang disebabkan oleh cedera pada otak. Salah satu komponennya merupakan gangguan otak. Dengan demikian Cerebral palsy dapat digambarkan kondisi ketidakfungsian gerak, bermula saat anak-anak, dicirikan dengan paralysis, kelemahan, kurang koordinasi, atau penyimpangan fungsi gerak lainnya yang disebabkan kelainan funhsi gerak pusat pegendali pada otak. Di samping disfungsi gerak tersebut, cerebral palsy bias menyebabkan terjadinya kesulitan belajar gangguan psikologis, kerusakan sensori, penyait kejang, dan behavioral pada origin organic."

Cerebral palsy dikalisifikasikan sebagai kelainan yang berbeda dengan kelainan neuromuscular, maka cerebral palsy meliputi kelainan spastic, athediot, ataksia, tremor dan rigid. Pada kasus-kasus yang ringan, anak spastic bias mengembangkan keseimbangan tangannya untuk sedikit mengendalikan gaya berjalan. Pada kasuskasus tingkat sedang, peserta didik spastik dalpat memegang lengan untuk diarahkan ke tubuhnya, membengkokkan sikunya dengan membengkokkan tangannya, dengan kaki yang diputar secara berhati hati paa lutut, dan menghasilkan jalan gaya gunting. Adapun pada kasus-kasus tingkat berat mereka memiliki pengendalian yang emah pada tubuhnya, tidak mampu 
duduk, berdiri atau berjalan tanpa bantuan alat penguat. Cirri utama peseta didik ataksia, gerakannya kurang kuat, berjalan dengan langkah yang penjang dan mudah jatuh, terkadang mata tidak terkoordinasi serta gerakan mata tertegun-tegun (nystamus). Pada termor dan rigid umumnya mereka mempuyai gagguan pada keseimbangan tubuh, disebabkan karena adanya kelaian pada postural dengan akibat hambatan otot yang berlawanan.

Hendaya kondisi fisik merupakan ketidakmampuan secara fisik untuk melakukan gerak. Ketidakmampuan seorang anak dengan adanya keterbatasan fisik nonsensori (fisik motorik), menyebabkan ia mempuanyai permasalahan untuk hadir ke sekolah dan belajr di kelas. Ketidakmampuan secara fisik motorik pada anak untuk melakukan gerakan tubuh menyebabkan ia membutuhkan layanan-layanan khusus, latihan dengan pola tertentu, peralatan-peralatan yang sesuai, dan fasilitas pendukung lainnya. Selain itu, anak yang mempunyai hendaya kondisi fisik, juga mempunyai hendaya penyerta lain seperti hendya perkembangan fusngsional, kesulitan belajar, gangguan emosional, kelainan berbicara dan berbahasa, atau mempunyai keberbakatan tertentu.

Anak dengan hendaya kondisi fisik memerlukan penanganan secara medis guna memperbaiki dan mengobati kelainan tubuhnya. Tetapi bila hendaya fisik tersebut mempunyai masalah pendidikan, maka pembelajaran khusus perlu penanganan oleh guru khusus di sekolah. Penanganan khusus oleh guru khusus memerlukan suatu metode pembelajaran yang bersifat khusus sesuai kelainan anak yang bersangkutan. Untuk hal ini gerak irama dapat diaplikasikan dalam program pembelajaran. Tujuannya yakni untuk mengembangkan keterampilan gerak siswa dengan hendaya kondisi fisik motorik. 
Umunya masalah utama pada gerak yang dihadapi oleh anak spina bifida adalah kelumpuhan dan kurangnya control gerak. Pada anak hydro-cephallus masalah yang dihadapi ialah mobilitas gerak. Anak dengan cerebral palsy mempunyai masalah dengan persepsi visual, meliputi gerakan-gerakan untuk menggapai, menjangkau dan menggemgam benda, serta hambatan dalam memperkirakan jarak dan arah (Lewis, V., 2003:157). Cerebral palsy merupakan kelainan koordinasi dan control otot disebabkan oleh luka (mendapatkan cedera) di otak sebelum dan sesudah dilahirkan atau pada awal masa anakanak (Hallahan \& Kauffman, 1991:345).

\section{Karakteristik Anak Tuna Ganda (Multiple Handicapped)}

Di Asia Timur belum banyak perhatian terhadap peserta didik yang memiliki kombinasi keluarbiasaan seperti tunanetra dan tunagrahita, cerebral palsy dan tunarungu, tunalaras dan tunagrahita, atau lainnya yang memiliki kelainan dua kali lipat atau lebih, dengan tingkat kelainan yang berat dang sangat berat (Jhonston \& Magrab, 1976:3). Penelitian yang menunjukkan bahwa keluarbiasaan yang berat dan sangat berat, seperti halnya anak-anak yang mempunyai kesulitan-kesulitan yang minor, jumlahnya meningkat (Anderson, 1969; Dibedenetto, 1976; Wolf \& Anderson, 1969). Kondisi semacam ii diperparah oleh sikap masyarakat terhadap keberadaan anak-anak yang mempunyai kombinasi hambatan perkembangan.

Definisi secara ringkas tentang anak tunaganda adalah sebagai berikut "Developmental disordes encompass group of deficit in neurogical development that result in important in one combination of skill areas such as: 
intelegence, motor, language, or personal social" (Jhonston \& Megrab, 1976:7). Dapat diartikan secara bebas bahwa "Tunaganda adalah mereka yang mempunyai kelainan perkembangan mencakup kelompok yang mempunyai hambatan-hambatan perkembangan neurologis yang disebabkan oleh satu atau dua kombinasi kelainan kemampuan seperti intelgensi, gerak, bahasa, atau hubungan probadi di masyarakat.

\section{J. Karakteristik Anak Berbakat dan Berkebutuhan (Giftness and Special Tallented)}

Pengertian anak berbakat dan keterbakatan dalam perkembangannya telah mengalami berbagai perubahan. Dimulai dengan pengertian yang berdasarkan pada pendekatan unidimensi atau factor tunggal (yang berpatokan pada IQ) ke pendekatan yang bersifat multidimensi atau factor jamak. Pengertian yang berdasarkan pada factor tunggal 9unidimensi) adalah pengertian yang menggunakan intelegensi sebagai keriteria tunggal dalam menentukan keterbakatan, tetapi keriteria jamak beruma kriteria-kriteria lain sebagai intelegensi. Dalam pendekatan multidimensi diakui adanya keragaman dalam konsep dan kriteria keberbakatan, sehingga diperlukan berbagai cara dan alat yang seragam dalam menentukan siapa anak berbakat dan keberbakatnnya (Amin, m.m 1996:1).

Perubahan konsep intelegensi dari factor tunggal seperti dikemukakan oleh terman ke faktor jamak seperti yang dikemukakan Guilford (dalam Myears, 1986) member pengaruh yang cukup besar terhadap konsep keberbakatan. Dalam pendekatan faktor tunggal, makna keberbakatan sama artinya dengan pemilikan intelegensi tinggi yang sifatnya genetis (keturunan). Adapun dalam pendekatan 
faktor jamak, keberbakatan tidak semata-mata ditentukan oleh factor genetis, tetapi juga hasil perpaduan interaksi dengan lingkungan. Menurut pendekatan jamak, keberbakatan ialah keunggulan dalam kemampuan tertentu yang berbeda-beda. Menurut Milgram, R.M. (1991:10), anak berbakat adalah mereka yang mempunyai skor IQ 140 atau lebih dikurur dengan instrument Stanford Binnet, (Terman,1925), mempunyai kreativitas tinggi (Gulford, 1956), kemampuan memimpin dan kemampuan seni drama, seni musik, seni tari, dan seni rupa (Marland, 1972). Peserta didik berbakat mempunyai empat kategori, yaitu:

1. Mempunyai kemampuan intelektual atau mempunyai intelegensi yang menyeluruh, mengacu pada kemampuan berppikir secara abstrak, dan mampu memecahkan masalah secara sistematis dan masuk akal. Kemampuan ini dapat diukur pada anak maupun orang dewasa dengan tes psikometrik berkaitan dengan prestasi umumnya dinyatakan dengan skor IQ.

2. Kemampuan intelektual khusus, megacu pada kemampuan yang berbeda dalam matematika, bahasa asing, musik, atau ilmu pengetahuan alam.

3. Berpikir kreatif atau berpikir murni menyeluruh. Umumnya mampu berpikir untuk memecahkan permasalahan yang tidak umum dan memerlukan pemikiran tinggi. Pikiran kreatif menghasilkan ideide yang produktif melalui imajinasi, kepintarannya, keluwesannya, dan bersifat menakjubkan.

4. Mempunyai bakat kreatif khusus, bersifat orisinil, dan berbeda dengan orang lain.

Program pendidikan khusus untuk anak berkebutuhan khusus.

1. Taman kanak-kanak ABK (4-7 tahun) 
2. Sekolah Dasar LB (7-12 tahun)

3. Program kurikulum: menuru Departemen Pendidikan Nasional yang dimodifikasi sesuai dengan kebutuhan anak.

4. Kegiatan di dalam kelas TK dan SD meliputi kegiatan pra-akademik melalui alat permainan edukatif, stimulasi motorik halus, motorik kasar, pengamatan, berbicara, sosialisiasi, dan kemandirian.

5. Kegiatan di luar sekolah meliputi latihan gerakan kasar, mengenal alam dan lingkungan, menggambar, menari, menyanyi, dan bermain alat musik.

Program Ekstrakurikuler:

Mengunjungi tempat-tempat umum seperti: kantor pos, museum, pasar, berenang, tempat pariwisata, dan permainan di alam bebas. Penanganan anak berkebutuhan khusus (ABK) sangat penting dilakukan. Semakin dini penanganan, semakin rendah resiko seorang anak terkena gangguan. Dalam menangani ABK, peran keluarga terutama orangtua, pihak sekolah, dan lingkungan sekitar sangat diperlukan. 


\section{BAB V \\ MENGEKSPLORASI, MENGENAL, MENGIDENTIFIKASI \\ DAN MENANGANI ANAK BERKEBUTUHAN \\ KHUSUS GANDA \\ (twice Exceptionality)}

\section{A. Pengertian Keluarbiasaan ganda (twice exceptionality}

Beberapa ahli memebri batasan pengetian tentang twice exceptionality antara lain:

1. Chamberlin \& Buchanan, menggambarkan individu-individu yang berbakat namun juga pada saat yang sama diidentifikasi sebagai anak yang memiliki kebutuhan khusus karena kecacatannya.

2. Baum, mendefenisikan anak yang twice exceptionality sebagai individu muda yang sama seperti anal berbakat lainnya, memiliki pengetahuan yang luas, intelegensi yang tinggi dan memiliki bakat dalam hal-hal tertentu. Mereka dapat berfikir dengan kritis dan menciptakan penyelesaian bagi berbagai masalah, namun juga dilingkupi oleh kesulitan belajar khusus yang menghambat perekmbangan mereka dan menahan bakat potensialnya. Dengan kata lain, anak berbakat yang juga memiliki kebutuhan khusus yang lain (seperti tuli dan buta) tidak dapat dikategorikan sebagai kesulitan belajar selama kekurangan tersebut tidak menghambat anak untuk mencapai prestasi 
akademis yang tinggi ataupun menghasilkan karya-karya yang luar biasa.

3. Olenchack dan Owen menjelaskan anak yang twice exceptionality sebagai anak-anak yang berbakat dan memiliki tingkat kreatifitas yang tinggi, namun selalu diikuti oleh kesulitan dalam memberikan perhatian.

4. Neihart mendefenisikan anak yang twice exceptionality dalam lingkup anak-anak yang berbakat yang juga memiliki sindrom aspergers.

Dari beberapa defenisi yang menjelaskan tentang keberbakatan dan anak-anak yang berkebutuhan khsusus di atas dapat dikatakan bahwa anak-anak dengan twice exceptionality merupakan individu-individu yang berbakat, namun pada saat yang bersamaan juga diidentifikasi sebagai anak yang memiliki kebutuhan khusus karena kecacatannya. Seringkali sisi keberbakatan ini bahkan tidak teridentifikasi.

Ada tiga kelompok besar yang dapat dibedakan anak yang twice exceptionality, yaitu: ${ }^{25}$

1. Yang telah diidentifikasikan berbakat, tetapi juga telah ditandai memiliki kesulitan belajar (learning disable), antara lain kesulitan mengeja bacaan dan jelek tulisannya serta tidak dapat mengelola dirinya (disorganized) dalam menyelesaikan tugasnya, malas, harga diri kurang dan sering disebut underachiever. Guru mengharapkan hasil belajarnya lebih karena telah diberi label berbakat, namun ternyata hasil

${ }^{25}$ Conny R. Semiawan dan Frieda Mangunsong, 2010, Keluarbiasaan Ganda (Twice Expectionality) Mengeksplorasi, mengenal, mengidentifikasi dan Menanganinya, (Jakarta: Kencana), h.2 
belajarnya kurang dibandingkan dengan teman sebaya lainnya.

2. Kelompok kedua tidak teridentifikasikan. Ini adalah kelompok yang terbesar, karena keberbakatan dan kekurangannya saling tertutupi. Mereka dianggap siswa rata-rata atau tampak seperti tidak memiliki kebutuhan luar biasa. Sebagian mereka tidak menampilkankejelasan tentang apa yang dikehendaki, namun menurut saja terhadap apa yang ditugaskan kepadanya. Mereka meskipun dapat mengikuti pelajaran di kelas, namun sebenarnya hasil belajarnya dibawah potensi yang dimiliki. Makin tinggi jenjang pendidikannya, makin tampak kesulitan belajarnya karena kebutuhan khsususnya tidak terdeteksi, dan tidak pernah memperoleh pendidikan sesuai kebutuhannya.

3. Kelompok ketiga adalah mereka yang telah diidentifkasikan berbakat, namun juga memiliki kesulitan belajar. Meskipun demikian, keberbakatanya tidak pernah ditangani. Sering sekali mereka justeru ditempatkan di kelas atau diposisikan dalam kelompok dimana keberbakatannya tidak tertampilkan dalam kinerja intelektualnya karena tertekan oleh kesulitan belajar. Kekuatan dan interesnya tidak diperhatikan oelh gurunya. Dikemudian hari, dalam mencari jalan keluar untuk kemampuan kreatifnya, maka dalam rangka menghindari tugasnya, mereka menjadi destruktif. Apabila kemampuan keberbakatannya tetap tidak teridentifikasikan. Lebih lanjut mereka akan 
tetap tidak peroleh layanan sesuai keberbakatannya.

Apabila potensi dan kemampuannya tidak ditemukan, maka ketiga kelompok ini akan mengalami resiko salah sosial emosional. Sebagai konsekwensi ssiwa ini sering gagal memenuhi tuntutan kriteria belajar karena tidak memperoleh layanan yang seharusnya.

\section{B. Identifikasi Anak dengan Twice Exceptionality}

Menurut Baum (2006), terdapat banyak sekali anakanak berbakat yang juga memiliki kekhususan lain namun tidak teridentifikasi. Setidaknya terdapat tiga kelompok anak-anak berkebutuhan khusus gandda yang tetap tidak akan terindentifikasi. Kelompok pertama adalah anak-anak yang telah diidentifikasi sebagai anak berbakat, namun memiliki kesulitan mengikuti kurikulum sekolah yang berlaku. Anak-anak ini sering kali diidentifikasi sebagai underachievers yang juga identic sebagai anak-anak yang memiliki konsep diri yang buruk, kurang memiliki motivasi untuk berprestasi, dan malas. Kekhususan yang mereka miliki tidak akan terlihat hampir di sepanjang kehidupan akademisnya. Ketika tuntutan dan beban akademis semakin bertambah mereka akan semakin terpuruk jauh di belakang rata-rata anak lainnya sampai seseorang menyadari kemungkinan kekhususan yang dialami anak-anak ini.

Kelompok ke dua mencakup anak-anak yan tingkat kekhususannya cukup tinggi sehingga dikategorikan sebagai anak-anak yang mengalami kesulitan belajar namun sis keberbakatannya tidak tidak pernah diketahui. Hasil penelitian yang dilakukan oleh baum (1985) menunjukkan bahwa kelompok ini tidak terdiri atas 
sejumlah kecil anak. 33\% siswa yang teridentifikasi sebagai siswa yang memiliki tingkat intelektualitas yang superior. Asesment yang tidak adekuat atau skor IQ yang rendah sering kali membuat kita meremehkan tingkat kemampuan intelektualitas anak-anak ini.

Mungkin kelompok terbesar yang tidak dilayani seperti sudah disampaikan dalam bab satu (1) dalam program-program pendidikan khusus adalah mereka yang kemampuan dan ketidakmampuannya saling menutupi satu-sama lain. Anak-anak ini duduk di kelas umum, dianggap tidak cukup berbakat untuk mendapatkan program khusus baik bagi anak berbakat maupun anak yang memiliki kesulitan belajar. Ketika tuntutan dan beban akdemisi mulai meningkat mulai meningkat, kesulitan belajar yang mereka alami mulai terlihat namun sisi potensi keberbakatan jarang sekali ikut teridentifikasi dengan baik bila asessmen dan diagnosis yang tepat tidak dilakukan dengan layak.

Selama ini, menemukan anak-anak yang tergolong berbakat dan sekaligus memiliki kekhususan yang menghambat perkembangan potensi anak sangatlah jarang dilakukan. Kebanyakan karena memang tidak ada yang berminat untuk mencari. Pada lingkungan sekolah, dimana anak-anak ini diberi label "lulus" atau "mengulang"atau "berkebutuhan khusus", "berbakat khusus", evaluator jarang sekali dengan sengaja mencari anak-anak yang memiliki kombinasi dari label-label tersebut. Mereka memang tidak pernah memperkirakan anak yang berbakat mungkin saja mengalami disleksia atau sebaliknya, anak yang memiliki cacat fisik ternyata memiliki cacat fisik ternyata memiliki bakat khusus yang jauh melampaui anak- 
anak lainnya. Anak-anak ini biasanya memiliki ciri-ciri sebagai berikut:

- Bakat dan kemampuan yang sangat menonjol

- Kesenjangan yang besar antara prestasi yang diharapkan dengan prestasi yang sesungguhnya diperoleh anak.

- Kesulitan untuk bergaul dengan teman-temannya.

- Self-esteem yang rendah.

- Prestasi akademis

- Terlihat malas dan ketidakmampuan untuk fokus dan berkonsentrasi

Menurut Clark (1998), menemukan anak berbakat di antara anak-anak berkebutuhan khusus tanpa asesmen dan diagnosis yang memadai sama artinya dengan berharap label yang telah diberikan pada anak memang benar-benar menunjukkan potensi anak yang sesungguhnya. Pada saat anak mendapatkan label tertentu, pada umumnya guru mengharapkan kebutuhan dan tingkah laku anak akan berkisar pada label normal yang biasanya terjadi pada anak-anak lain dengan label yang sama, padahal kebutuhan dan tingkah laku ssetiap individu sangatlah berbeda. Pada kondisi seperti ini, keberbakatan seringkali tidak teridentifikasi dengan baik. Bahkan pada saat kemungkinan keberbakatan yang dimiliki mulai terlihat, sering kali sangat sulit bagi anak twice exceptional untuk mendapatkan program khusus bagi anak-anak berbakat lainnya karena kekhususan yang dimilikinya. Pada banyak kasus, anakanak berkebutuhan ganda atau dual exceptionality dan baru disadari adanya keberbakatan setelah kekhususankekhusuannya teratasi. 


\section{Keberbakatan}

Anak-anak berbakat adalah mereka yang diidentifikasi oleh para profesional yang qualified sebagai pribadi-pribadi yang memiliki kemampuan yang sangat mengagumkan, dan mampu menunjukkan tingkat performa yang tinggi. Anak-anak ini adalah orang-orang yang membutuhkan program pendidikan yang berbeda untuk dapat memperlihatkan dan menyumbangkan kemampuan mereka kepada masyarakat. Anak-anak ini mampu menunjukkan performa pencapaian prestasi yang tinggi dalam beberapa bidang berikut ini, baik secara terpisah maupun kombinasi dari beberapa bidang ini:

1. Memiliki kemampuan intelektual yang tinggi secara umum

2. Memiliki kecenderungan perilaku akademis tertentu

3. Pemikiran yang produktif dan kreatif

4. Kemampuan kepemimpinan

5. Kemampuan visual dan seni yang baik

6. Kemampuan psychomotor (Marland, 1972, p.2 as cited in Andrews \& Lupart, 2000)

Individu-individu yang berbakat biasanya juga memiliki kharakteristik- kharakteristik afektif (Albert Learning, 2000; Pfeiffer \& Stocking, 2000). Perfektonis adalah salah satu bentuk kharakteristik yang sering kali menunjukkan keberbakatan pada seseorang. Seringkali, anak-anak berbakat ini adalah anak-anak yang memiliki prestasi akademis yang baik, anak-anak yang memiliki kegigihan yang tinggi dan memperlihatkan standar diri yang juga tinggi. Mereka dapat dengan mudah dibangkitkan. Individu-individu berbakat sering kali muncul sebagai probadi yang menarik, menarik, energik dan sering kali melompat dari satu hal yan dianggap menarik ke hal yang 
lain. Tidak jarang mereka juga memperlihatkan tekanan sensitivitas, empati dan kepedulian yang tinggi pada semua hal yang hasilkan oleh sensitivitas moral dan integritasnya. Mereka dapat terlihat sebagai pribadi yang reflektif, instrospektif dan memiliki selera humor yang baik.

\section{Faktor-faktor Pelindung}

Secara akademis, anak-anak berbakat memiliki kharakteristik yang sama dengan individu-individu yang memiliki resiliensi yang baik (Neihart, 2002). Trait-trait ini mencakup kemampuan verbal yang superior, inteligensi yang tinggi, pengambilan risiko, konsep diri yang tinggi, efikasi diri yang baik, prestasi akademis yang baik, reflectiveness, tingkat kematangan di atas anak-anak seusianya, memiliki locus of control internal dan pemahaman yang baik akan dirinya sendiri(Dole, 2000). Karena kemampuan kognisinya yang superiornya, anakanak berbakat ini mampu menghadapi stres dengan lebih baik dan biasanya memiliki dua gaya adaptasi terhadap stres: gaya adaptasi dengan fokus terhadap masalah dan gaya adaptasi dengan fokus dengan fokus pada emosional. Pada gaya adaptasi dengan fokus pada masalah, anak berbakat biasanya menghargai lingkungan mereka dengan mengubah tingkah laku untuk menyenangkan lingkungan atau individu lain dalam lingkungan. Pada gaya adaptasi dengan fokus pada emosional, individu cenderung mengubah interpretasi mereka terhadap lingkungan. Sowa dan clntire, menemukan bahwa anak-anak berbakat mengubah tingkah lakunya untuk menyenangkan lingkungan sekitar. Sebagai contoh, seorang anak mengubah caranya menyampaikan argumentasi karena ia menyadari orang-orang bereaksi dengan marah dan hal 
tersebut membuatnya kehilangan kesempatan untuk mendapatkan hasil seperti yang diinginkan.

Neihart (1999) menyatakan bahwa psychological wellbeing (kesejahteraan mental) dari anak-anak berbakat akan sangat tergantung pada jenis keberbakatan yang dimilikinya, kecocokan jenis pendidikan yang diterima dan karakteristik probadi dari anak berbakat itu sendiri. Anakanaka berbakat memiliki risiko masalah psikologis yang sama besarnya seperti juga anak-anak lain yang tidak mendapatkan diagnosis berbakat. Neihart juga menyatakan bahwa anak-anak yang sangat berbakat (dengan skor IQ 160 atau lebih) sangat rentan terhadap masalah sosial dan emosional. Bahkan, perpaduan dari kesempatan pendidikan yang sesuai dan tingkat keberbakatanlah yang lebih banyak memberikan konstribusi positif pada anak-anak yang tingkat keberbakatannya sangat tinggi ini. Neihart juga menyimpulkan bahwa anak-anak yang berbakat secara intelektual dan akademis yang mendapatkan program pendidikan khusus untuk anak berbakat dapat menyesuaikan diri sama baiknya atau bahkan lebih baik dibandingkan dengan teman-temannya yang tidak berbakat.

Selain kepercayaan sosiokultur yang memercayai bahwa anak-anak berbakat adalah individu yang superior secara intelektual, sosial, emosional dan fisik (Yewchuk, 1983), anak-anak berbakat juga sangat rentan terhadap beberapa hal yang menjadi faktor risiko dan membutuhkan faktor-faktor pelindung untuk memfasilitasi tercapainya kehidupan yang baik.

Identifikasi twice exceptionality dapat dilakukan dengan berbagai cara di antaranya dengan: 
- Mengikutsertakan siswa-siswa yang meiliki kebutuhan khusus dalam setiap tahapan skrining.

- Bersedia untuk menerima indikator-indikator baru dari bakat intelektual yang di tunjukkan anak.

- Tidak hanya melihat dan menilai anak melalui skor tes.

- Ketika mengaplikasikan batasan nilai terendah dan tertinggi dari sebuah tes, ingat bahwa nilai yang sangat rendah mungkin muncul karena adanya kekhususan tertentu yang dimiliki anak.

- Jangan menjumlahkan skor sub tes sebagai skor yang berbeda dengan keseluruhan skor sesungguhnya.

- Bandingkan dengan skor anak-anak lain yang memiliki kekhususan yang sama.

- Lebih menitikberatkan pada karakteristik yang memungkinkan anak untuk mengkonpensasi kekurangannya dengan efektif.

- Lebih menitikberatkan pada area performa yang tidak terpengaruh oleh kekhususan anak.

- Mengizinkan anak untuk mengikuti program dasar bagi anak-anak beerbakat.

- Berhati-hati dengan menerapkan aturan pada hal-hal yang menjadi kelebihan siswa seperti bahasa; kurangi pembatasan komunikasi dan bangun model alternatif dalam berfikir dan berkomunikasi. 
- Menekankan pendekatan pemikiran abstraksi, kreativitas dan penyelesain masalah tingkat tinggi.

- Menyediakan aktivitas yang menantang

- Dukung kegiatan yang memancing pertanyaan dan penjelasa, eksperimen dan diskusi.

- Dukung kegiatan yang membutuhkan pengarahan diri pada anak.

- Berikan pilihan yang memungkinkan siswa untuk menggunakan kelebihannya dan memilih cara untuk belajar.

- Gunakan kekuatan intelektual untuk membangun konsep diri yang positif pada anak. Dapat dilakukan dalam membangun dinamika kelas.

- Diskusikan dampak dari kemampuan dan ketidakmampuan mereka dengan seisi kelas.

\section{E. Perlakukan Anak-anak Berkebutuhan Khusus}

Identifikasi pada anak berbakat dengan cacad fisik dapat dilihat dari hal-hal seperti:

a. Perkembangan kemampuan kompensatoris

b. Kreatif dalam menemukan cara-cara alternatif dalam berkomunikasi dan menyelesaikan tugas

c. Memiliki pengetahuan yang jelas

d. Kemampuan akademis yang di atas rata-rata anak seusianya.

e. Memiliki ingatan yang superior

f. Memiliki kemampuan penyelesaian masalah yang tinggi

g. Cepat mendapatkan ide 
h. Kemampuan untuk menetapkan dan mencapai tujuan jangka panjang

i. Lebih dewasa dibandingkan dengan teman-teman seusianya

j. Memiliki selera humor yang baik

k. Teguh dan sabar

l. Bermotivasi untuk berprestasi

$\mathrm{m}$. Memiliki rasa ingin tahu yang tinggi

n. Self-criticism dan perfeksionis

o. Perkembangan kognisi berdasarkan pengalaman tidak langsung

p. Kemungkinan memiliki kesulitan dalam abstraksi

q. Kemungkinan memiliki keterbatasan dalam pencapaian prestasi karena keterbatasan fisik. (Celine, 1999; Whitemore \& Maker, 1985; WillardHolt, 19994).

Identifikasi pada anak berbakat dengan kesulitan belajar dapat dilihat dari hal-hal seperti:

a. Memiliki kemampuan nalar abstraksi yang tinggi

b. Memiliki kemampuan nalar matematis yang baik

c. Menyukai ingatan visual dan memiliki kemampuan spasial yang baik

d. Memiliki perbendaharaan kata yang kaya

e. Selera humor yang baik

f. Imaginatif dan kreatif

g. Banyak ide

h. Memiliki kemampuan yang tinggi di bidang geometri, sains, seni, dan music

i. Kemampuan menemukan dan menyelesaikan masalah yang baik

j. Memiliki kesulitan ingatan, hitungan, dan ejaan

k. Mudah terganggu dan tidak teratur 
1. Supersensitif

m. Perfeksionis

n. Cepat memahami metapora, analogi, dan satire

o. Memiliki pemahaman sistem komprehensif yang kompleks

p. Memiliki pengharapan terhadap diri sendiri yang berlebihan

q. Seringkali gagal untuk menyelesaikan tugas tepat pada waktunya

r. Kesulitan dengan tugas-tugas sekuensial

s. Memiliki ketertarikan pada banyak hal (Baum, Owen, \& Dixon, 1991; Silverman, 1989)

\section{F. Assesmen dan Diagnosis}

Masalah utama dalam mengidentifikasi apakah seorang anak termasuk twice exceptionality, anak harus mendapatkan dua diagnose yang berbeda. Keberbakatan seringkali tersembunyi di balik kekhususan lain dalam bentuk ketidakmampuan tertentu, dan ketidakmampuan ini dapat menekan skor tes sehingga sulit untuk mendapatkan hasil assesmen yang valid (Silverman, 1989), Davis and Rimm (1989, dalam Lovett \& Lewanddowski, 2006) menekankan bahwa mengedentifikasi keberbakatan pada siswa yang memiliki kebutuhan khusus membutuhkan prosedur yang berbeda dengan assesmen bagi individu berbakat pada umumnya. Davis \& Rimm merekomendasikan penggunaan behavior rating scale, creativity inventories, peer or self-nominations, dan prolonged student observation.

Untuk menyatakan bahwa seorang anak termasuk sebagai anak dengan twice exceptionality atau bukan, kita harus mempertimbangkan berbagai jenis informasi, termasuk assesmen yang mendalam dari kedua sisi 
kekhususan anak. Evaluasi yang dilakukan harus juga mencakup;

a. Tes intelegensi individual

b. Tes diagnostic prestasi

c. Evaluasi tingkat kreativitas oleh ahlinya atau oleh guru

d. Evaluasi teman sebaya akan kemampuan kepemimpinan

e. Wawancara dengan orang tua

f. Pengamatan interaksu dengan teman sebaya di dakam kelas dan performa lainnya

g. Tes bakat dan tes krestivitas

Mengidentifikasi keberbakatan pada anak-anak berkebutuhan khusus merupakan masalah tersendiri. Metode identifikasi yang biasa-tes terstandarisasi dan checklists observasi-tidak cukup adekuat tanpa beberapa modifikasi utama.

Karakteristik standar dari anak-anak berbakat bisa dikatakan tidak adekuat bila digunakan untuk melihat potensi tersembunyi dari anak-anak yang mengalami cacat pendengaran sebagai contoh, tidak dapat memberikan respon terhadap instruksi yang diberikan secara lisan, dan mereka juga memiliki keterbatasan penbendaharaan kata untuk mengungkapkan pikiran mereka. Anak-anak tunawicara tidak dapat memberikan respon terhadap tes yang membutuhkan respon secara verbal. Anak-anak penyandang tunanetra akan mengalami kesulitan untuk memberikan respon terhadap beberapa pengukuran jenis performa, dan walaupun perbendaharaan kata mereka cukup banyak, mereka seringkali tidak memahami arti katakata yang mereka gunakan (contohnya, warna). 
Anak-anak yang mengalami kesulitan belajar mungkin memang memiliki perbendaharaan kata yang kaya dalam berbicara, tapi tidak dapat mengekspresikan dirinya sendiri dalam menulis, dan sebaliknya. Keterbatasan inilah yang membuat anak-anak berkebutuhan khusus pada umumnya mendapatkan skor tes yang cenderung rendah (Whitemore \& Maker 1985). Karena keberadaan anak-anak berbakat yang juga berkebutuhan khusus ini sangat jarang sekali diikutsertakan dalam standarisasi norma kelompok sebuah tes.

Anak-anak berbakat yang memiliki kesulitan belajar biasanya memiliki konsep diri yang lebih rendah dibandingkan dengan anak-anak berbakat ( Van TasselBaska, 1991), mereka juga memiliki kesan yang tidak begitu baik mengenai pendidikan akademis yang mereka terima di sekolah dan memiliki prestasi yang lebih sedikit di luar bidang akademis dan sekolah (seperti kepemimpinan, altetik dan seni) bila dibandingkan dengan teman-teman mereka yang lain (Gallagher, 1997). Lebih jauh lagi dalam suatu penelitian diketahui bahwa para guru menganggap anak-anak ini sebagai anak yang tidak mau bergaul, tidak popular, dan kurang diterima oleh teman-temannya dibandingkan dengan anak-anak berbakat yang tidak memiliki kesulitan belajat (Waldron, Saphire, \& Rosenblum, 1987).

Kebingungan yang dialami oleh anak twice exceptionality karena dua kekhususan yang dimilikinya saling bertolak belakang dapat menimbulkan rasa frustasi, kesedihan, dan menarik diri dari lingkungan (Baum \& Owenm 1988; Norton, 1996; Silverman, 1989). Konflik perasaan yang dialami juga dapat ditunjukkan anak dalam bentuk kemarahan dan kebencian terhadap orang lain 
sehingga mempengaruhi hubungan dengan teman sebaya dan keluarg (Mandaglio, 1993). Tingkah laku yang muncul dalam bentuk agresi, menarik diri, dan ketidakmampuan mengontrol diri ini dapat terjadi baik di rumah maupun di lingkungan sekolah (Van Tassel Baska, 1991).

\section{G. Dampak Emosional dan Psikologis}

Mislabeling dan misdiagnosis yang diterima oleh anak berbakat bersekuensi sangat tragis bagi kondisi emosional dan psikologis dan keluarganya. Hal ini bahkan berdampak pada cara msyarakat sekitar memperlakukan anak twice exceptionality yang mendapatkan diagnosis dan label yang tidak tepat. Perlakuan orang tua dan anggota keluarga lain, teman sebaya, dan guru mereka sesuai label yang tertera karena kesalahan diagnosis sangat mungkin membuat anak menjadi pribadi yang gelisah, pengeluh, sinis, pembangkang, dan depresi.

Anak-anak berbakat yang memiliki konsep diri yang lebih rendah dibandingkan dengan anak pada umumnya sehingga terlihat sebagai anak yang rendah diri, tidak mau bergaul, tidak popular, dan cenderung menarik diri dari lingkungannya. Kebingungan yang dialami oleh anak twice exceptionality karena dua kekhususan yang dimilikinya saling bertolak belakang dapat menimbulkan rasa frustasi, kesedihan, dan menunjukkan konflik perasaan yang dialami dalam bentuk kemarahan dan kebencian terhadap orang lain. Tidak jarang muncul tingkah laku dalam bentuk agresi, dan ketidakmampuan untuk mengontrol diri, baik di rumah maupun lingkungan luar. 


\section{H. Perkembangan akademis}

Kegagalan dan kesalahan dalam penanganan kekhususan anak-anak twice exceptionality yang terjadi karena kesalahan diagnosis dan label dari masyarakat cenderung mendorong anak dengan twice exceptionality menghindari kegiatan belajar secara akademis sehingga menghambat proses maksimalisasi potensi sesungguhnya. Seringkali anak-anak twice exceptionality ini melakukan usaha-usaha yang sangat besar di bidang-bidang yang menjadi kekhususannya agar terlihat sama dengan temanteman seusianya sehingga kemampuan yang sangat jelas terlihatpun tida terindentifikasi. Dan konsekuensinya sangat tragis, baik bagi si individu, keluarga maupun masyarakat sekitar. Seringkali terjadi, bahkan pada saat kekhususan ini teridentifikasi, tetap tersedia pendidikan khusus sehingga kesempatan bagi anak untuk berkembang terhabisi begitu saja.

Walaupun demikian identifikasi awal dan intervensi dapat membuat kekhususan anak tidak menghalanginya untuk berprestasi, sering kali tindakan pencegahan tidak dilakukan baik oleh orang tua maupun oleh guru (Kauffman, 2005; Stichter, 2008), sehingga menyebabkan kegagalan dengan konsekuensi yang sangat besar terhadap keinginan anak untuk belajar, self esteem, mood, dan tingkah lakunya.

Dalam perkembangan kemampuan akademisnya, mereka sering kali menyalahkan diri sendiri atas kesenjangan antara kemampuan mereka dengan performa nyata yang mereka tunjukkan. Sering kali mereka hanya menyerah dan mulai menyepelekan segala hal termasuk hal-hal yang seharusnya mampu mereka kuasai dengan baik. Mereka juga memiliki kesan yang tidak begitu baik 
mengenai pendidikan akademis yang mereka terima di sekolah dan memiliki prestasi yang lebih sedikit di luar bidang akademis, dan sekolah, (seperti kepemimpinan, atletik, dan seni) bila dibandingkan dengan teman-teman mereka yang lain.

Anak-anak twice exceptionality -terutama ang mengalami kesuliatan belajar- sering kali menyerah untuk mencegah untuk mencoba, karena rasa takut mereka terhadap kegagalan dank arena mereka terbiasa untuk dituntut berprestasi oleh lingkungan sekitanya. Hal ini kemudian membuat kebanyakan guru dan pengajar beranggapan bahwa kekhususan anak-anak ini mempengaruhi semua aspek prestasi mereka.

Di lapangan, asesor sekolah (school-based assessor) seyogyanya memiliki kriteria yang lebih terstandarisasikan daripada psikolog atau konselor pendidikan perorangan dalam melakukan diagnosis terhadap keuarbiasaan ganda (twice exceptionality). Hal tersebut sebenarnya harus tampak karena adanya perbedaan yang signifikan antara mereka yang kehidupan intelektualnya memiliki rentangan intelektual rata-rata dan intelektual tinggi. Apalagi yang ketidakmampuannya (disability-nya) bersifat ringan (mild) seperti pendengaran atau pembicaraan (speech) yang terkadang merupakan gangguan ringan, sering kali terlewat didiagnosa sebagai anak berbakat, sehingga mereka mengalami kerugian dalam menempuh hidupnya., dan dianggap seseorang yang mediocre (sedang) kemampuannya.

Seyogianya kekuatan dan kelemahan yang didiagnosis sekaligus dalam dirinya, harus dihadapakan pada kurikulum yang bermakna dalam memenuhi 
kebutuhan keluarbiasaanm keberbakatan maupun pendidikan khusus untuk kelemahannya. Yang diperlukan di samping keurikulum untuk anak berbakat adalah pembelajaran selangkah demi selangkah (step by step) dalam mengatasi keterampilan lainnya yang lemah.

Contoh kasus yang sangat obvious (nyata) tentang Jefferson (anak Indonesia) yang menggambarkan riwayatnya sebagaimana anak yang berbakat luar biasa ditemukan "keberbakatan"-nya, setelah beberaoa tahun dihukum sebagai seseorang yang tidak memiliki kemampuan untuk belajar dan diperkirakan seorang autis oleh seorang dokter anak.

Beberapa jenis kekhususan dan kesulitan belajar dangat spesifik sifatnya. Karenanya kelemahan seorang siswa dapat berpengaruh pada salah satu pelajaran namun tidak pada pelajaran yang lain, atau hanya terjadi pada tingkatan tertentu saja. Kebanyakan dari jenis kesulitan belajar berdiri terpisah dengan kemampuan kognitif. Setiap anak pada semua tingkat intelektual (termasuk yang berbakat) dapat memiliki kesulitan belajar.

\section{Layanan atau Bantuan/Intervensi}

Anak-anak ini membutuhkan pendidikan secara khusus dirancang untuk memenuhi kebutuhan yang tidak biasa dari anak-anak berkebutuhan khusus (Huefner, 2006) yang mungkin membutuhkan materi khusus, teknik mengajar atau peralatan dan atau fasilitas. Siapa yang mendidik anak-anak berkebutuhan khusus, dan di mana mereka akan menerima pendidikan khusus tergantung pada seberapa besar siswa berbeda dari siswa-siswa pada 
umumnya sumber daya apa yang tersedia dalam sekolah, keluarga dan masyarakat.

Anak-anak twice exceptionality membutuhkan pendidikan yang berbeda karena mereka berbeda dari kebanyakan siswa lainnya dalam hal-hal berikut ini: anakanak ini mungkin memiliki ketidakmampuan dan atau kesulitan untuk memberikan perhatian dan belajar, gangguan emosional dan tingkah laku, kecacatan fisik, gangguan komunikasi, autistik, traumatic brain injury, cacat pendengaran, cacat penglihatan, namun juga memiliki bakat dan kelebihan tertentu.

Anak-anak berkebutuhan khusus ganda ini juga berbeda dari kebanyakan anak-anak lainnya dalam hal yang berkaitan dengan pendidikan mereka. Perbedaan kebutuhan dalam pendidikan ini menuntut instruktur dan instruksi yang juga berbeda dari anak-anak pada umumnya. Mereka harus dibantu untuk memperluas kekuatannya dan mengatasi kelemahannya; sayangnya, kebanyakan dari anak-anak ini telah diberi label dan dipaksa untuk mengikuti gaya hidup yang berbeda hanya karena seseorang telah mengkategorikan mereka sebagai bentuk fungsi pada batas bawah sebuah kontinum, dan bukan berdasarkan pada kenyataan yang sesungguhnya terjadi (Hart, 1981).

Adalah suatu tantangan tersendiri untuk melayani ataupun membantu maupun menyelenggarakan suatu intervensi yang merupakan suatu strategi yang jitu memenuhi kebutuhan siswa yang termasuk kelompok keluarbiasaan ganda, yaitu meliputi kebutuhan keberbakatannya maupun jenis kesulitan belajar yang dialami. Tidak ada satu solusi yang dapat dikatakan sebagai 
solusi terbaik untuk memenuhi kebutuhan anak-anak twice exceptionality. Keputusan yang dibuat haruslah berdasarkan berbagai pertimbangan akan faktor-faktor yang ada, termasuk kelebihan dan kekurangan anak, pilihan orang tua, jenis program keberbakatan, dan pertimbanganpertimbangan lain.

Ada baiknya dicoba beberapa strategi yang berbedabeda untuk sampai pada cara yang paling cocok bagi seseorang tertentu. Berbagai penelitian (Kerr, 2009), menunjukkan bahwa strategi efektif bagi mereka memiliki beberapa ciri tertentu yang menghadirkan kemungkinan intervensi efektif sebagai berikut:

a. Libatkan siswa-siswa ini dalam suatu kerja tim dengan anak berbakat, dan juga melibatkan guru PLB

b. Selain itu, siswa pada umumnya juga bergaul dengan kelompok ini, agar terwujud kelompok belajar yang memahami tentang kekurangan dan keterbelakangannya

c. Pemahaman tentang masing-masing kekuatan dan kelemahan diperoleh melalui interaksi dan pemahamannya tentang telanta kekuatan dan interesnya.

\section{J. Proses Pembelajaran}

Program untuk anak twice exceptionality dapat berbentuk berbeda-beda sesuai dengan kekhususan yang dimiliki anak, seperti: 
a. Program pengayaan di mana siswa mendapatkan tembahan bantuan pada hal-hal yang menjadi kekhususannya

b. Program terpisah yang terfokus pada kelebihan dan kekurangan yang dimiliki oleh anak

c. Program remediasi

Para pendidik terkait harus memastikan siswa menerima pelayanan yang selayaknya harus kreatif dalam mencari solusi. Mereka harus bekerja sama dengan baik dengan para pendidik anak cacat maupun para pendidik anak berbakat. Memang masih sangat sulit bagi kebanyakan orang untuk tidak hanya menerima anak-anak berkebutuhan khusus yang juga berbakat, tapi juga untuk memahami bahwa program khusus ini memang sulit bagi kebanyakan orang untuk tidak hanya menerima anak-anak berkebutuhan khusus yang juga berbakat, tapi juga untuk memahami bahwa program khusus ini memang benarbenar dibutuhkan.

Terlepas dari program apa yang disepakati untuk diberikan kepada anak twice exceptionality, tetap aka nada beberapa masalah utama dalam kelas karena paduan yang unik antara anak berbakat dan anak berkebutuhan khusus. Interaksi dua jenis kekhususan yang saling bertentangan ini akan menghasilkan anak-anak yang terus menerus merasa frustasi dan sekaligus juga menginspirasi. Memberikan berbagai stretegi mengajar merupakan cara tercepat untuk mengetahui metode apa yang paling baik dan dapat digunakan untuk anak. 
Berikut ini merupakan beberapa saran yang dapat dilakukan oleh guru kelas.

1. Untuk masalah akademis

a. Menyajikan materi pelajaran dengan berbagai cara (secara visual, ceramah, dan kinestetis) menyalin ulang materi pengajaran yang telah direkam oleh orang tua, siswa lain ataupun para relawan

b. Memberi kesempatan untuk berbagi pengetahuan dengan berbagai cara (rekaman laporan, tes oral, dan demonstrasi di kelas)

c. Menyediakan pengalaman belajar alternatif yang tidak tergantung pada kertas dan pensil (seperti puzzles, permainan logis, tangrams, manipulasi matematika)

d. Menempatkan siswa di mana guru dan papan tulis dapat dengan mudah terlihat

e. Beri batas waktu yang realistis dalam menyelesaikan tugas (sering kali harus lebih lama dari anak-anak lain)

2. Untuk membangun kemampuan kompensatoris

a. Ajarkan mengetik dan menggunakan komputer. Dorong anak untuk menggunakan kalkulator dan tape recorder sebagai alat bantu

b. Ajarkan strategi organisasional dan strategi penyelesaian masalah menggunakan cognitive behavior therapy modification techniques

Di dalam kelas penting diingat bahwa pendekatan:

c. Pengatasan masalah (problem solving)

d. Keterampilan mengatur waktu

(time management skill)

e. Teknik organisasional (organizational) 
f. Pelatihan keterampilan sosial (social skill training) harus intensif dilakukan

3. Afeksi

a. Kurangi tekanan prestasi akademis untuk mengurangi rasa frustasi dan menurunnya motivasi

b. Gunakan aktivitas-aktivitas seperti klarifikasi nilai-nilai dan bermain peran

c. Gunakan permainan untuk mendorong siswa untuk bicara, adakan pertemuan kelas untuk membahas perasaan dan masalah yang terjadi di kelas

d. Bawa twice exceptionality dewasa yang sudah sukses sebagai role model

e. Jelaskan bagaimana rasanya menjadi anak berkebutuhan khusus pada saat yang sama

f. Ajari anak twice exceptionality untuk menghargai dirinya sendiri sebagai manusia yang kuat dan cerdas

Orang tua harus menjadi pendukung dan pemberi nasehat yang efektif bagi anak-anaknya. Langkah pertama untuk menjadi pemberi nasehat yang baik adalah dengan belajar banyak sebanyak mungkin tentang anak-anak twice exceptionality. Orang tua sering kali merasa marah dan frustasi karena dua kekhususan anaknya saling bertolak belakang. Ada banyak alasan kompleks yang menjelaskan kondisi ini, dan tidak sepantasnya bila kondisi yang tidak mudah untuk dijelaskan ini dilabel dengan tingkah laku seperti "malas".

a. Terima kondisi anak anda dan ketahui semua kekhususan yang dimilikinya, baik kelebihan 
maupun kekurangannya. Hargai kesuksesan yang dilakukan anak

b. Sediakan kondisi lingkungan yang memperkaya khasanah belajar anak (wisata, puzzles, materialsm dan diskusi mengenai topik-topik yang menarik bagi keluarga

c. Libatkan anak dalam pengambilan keputusan mengenai kehidupan mereka, termasuk membuat kesepakatan tugas-tugas sekolah atau memutuskan untuk mengganti salah satu program khusus dengan program yang lain

d. Jangan bandingkan anak anda dengan anak lainnya

Sering kali orang berasumsi bahwa anak-anak yang berkebutuhan khusus dapat ditolong dengan mudah melalui obat-obatan dan terapi singkat. Tidak ada cara yang mudah untuk menolong anak-anak dengan kebutuhan khusus. Bahkan obat yang diberikan kepada anak-anak penderita ADHD hanya dapat mengurangi simtom yang ada dan tidak mengobati kelainannya. Karena kebanyakan dari jenis kekhususan seseorang biasanya dialami seumur hidup, maka dukungan, pengertian, dan perhatian untuk anak-anak yang memiliki kekhususan ini pun harus berdasar pada perlakuan seumur hidup.

Anak-anak dengan twice exceptionality tidak perlu untuk diperbaiki. Mereka bukan benda yang rusak. Mereka hanya membutuhkan bimbingan agar mampu menghadapi kekuatan dan bakat yang dimiliki oleh anak twice exceptionality akan mempersiapkannya untuk mengabdi pada masyarakat dengan pasti. Anak-anak ini adalah individu-individu yang cerdas, senstif, dan kreatif yang membutuhkan bimbingan dan dukungan dari sekitarnya. 
Ada banyak hal yang dapat dilakukan dalam memberikan bantuan bagi anak-anak dengan twice exceptionality seperti intervensi dalam bentuk bimbingan dan konseling, konsultasi dengan melibatkan peranan orang tua, menetapkan strategi pembelajaran bersama guru dan pembimbing, konseling pribadi dan grup konseling bagi siswa, dan advokasi. Program pendidikan khusus seperti integrasi, mainstreaming dan inklusi dapat dilakukan untuk membantu anak-anak ini, sejauh program tersebut memang memenuhi kebutuhan anak berprestasi. Hal yang perlu ditekankan dalam hal ini adalah jangan sampai kekhususan yang mereka miliki menghambat kita untuk mengenali kemampuan-kemampuan yang mereka miliki karena karakteristik yang terpenting dari twice exceptionality adalah kemampuan dan keberkatan yang dimilikinya. 


\section{BAB VI}

\section{KARAKTERISTIK KELUARGA, PENGARUH DISABILITY \\ PADA KELUARGA, RESPON KELUARGA TERHADAP \\ DISABILITY, DAN PERAN KELUARGA BAGI \\ PENDIDIKAN ANAK BERKEBUTUHAN \\ KHUSUS}

\section{A. Peran keluarga ABK}

Tidak ada elemen terpenting bagi tumbuh kembang anak berkebutuhan khusus seperti pentingnya peranan keluarga. Ada beberapa sikap keluarga dalam menghadapi ABK. Tidak sedikit keluarga yang menganggap kelahiran ABK sebagai aib keluarga, yang perlu untuk dirahasiakan, disimpan rapat-rapat, bahkan terbesit keinginan agar mereka segera menghilang entah kemana. Ada juga keluarga yang bisa menerima mereka, tetapi tidak tahu harus berbuat apa, mereka hanya sekedar diberi makan dan minum, dirawat apa adanya, seolah-olah hanya karena kewajiban merawat sembari menunggu waktu panggilan kea lam sebelum dia dilahirkan.

Ada segelintir keluarga yang bisa menerima kehadiran mereka sebagai anugerah, sebagai manusia yang juga memiliki kelebihan di samping kekurangannya. Mereka dididik dengan layak, tumbuh kembanganya diperhatikan dengan seksama. Sehingga seringkali terbukti,mereka adalah anak-anak yang luar biasa, yang memiliki kelebihan super dan mampu melewati kemampuan manusia normal pada umumnya. 
Kelahiran seorang anak memiliki dampak yang sangat signifikan pada dinamika sebuah keluarga. Orangtua dan anak-anak yang terlahir terlebih dahulu harus melakukan berbagai hal untuk beradaptasi dengan kehadiran anggota keluarga yang baru. Lahirnya seorang anak yang memiliki kebutuhan khusus di tengah-tengah keluarga dapat memberikan dampak yang jauh lebih berat, terlebih lagi bila saudara yang lahir ini merupakan anak berkebutuhan ganda yang keberkatannya sering kali tidak teridentifikasi sejak awal.

Beberapa hasil penelitian yang dilakukan menunjukkan bahwa orang tua yang memiliki anak berkebutuhan khusus mengalami beban stress yang jauh lebih berat dibandingkan dengan orang tua lainnya ( lessenberry \& Rehfeldt, 2004, dalam Kauffman dan Hallahan, 2009). Stress yang dialami biasanya bukan merupakan hasil dari rangkaian peristiwa yang tidak menyengkan, namun merupakan konsekuensi dari tanggung jawab sehari-hari dalam perawatan anak

Faktor yang paling mudah untuk diramalkan tentang bagaimana orangtua akan beradaptasi dengan stress yang dialami adalah kondisi psikologis utama orang tua, kebahagiaan dan kualitas perkawinan, dan tingkat dukungan informal yang mereka terima dari orang lain. Walaupun terdapat pengecualian, namun dapat dikatakan bahwa orang tua yang dapat menyesuaikan diri dengan baik dan memiliki pernikahan yang bahagia sebelum lahirnya anak berkebutuhan khusus memiliki kesempatan yang lebih baik untuk coping dengan situasi daripada mereka memiliki masalah psikologis dan masalah pernikahan. Dukungan sosial yang diterima oleh orang tua satu sama lain, anggota keluarga besar, kerabat dan yang 
lainnya dapat menjadi hal penting yang dapat menolong mereka untuk bertahan dalam menghadapi tekanan membesarkan anak yang berkebutuhan khusus. Dukungan ini dapat berupa bentuan fisik seperti tawaran bantuan untuk mengasuh anak, atau dapat juga berbentuk bantuan psikologis. Memiliki seseorang untuk berbicara mengenai masalah yang sedang dihadapi dapat sangat menolong.

Disinilah letak permasalah utama keberhasilan pendidikan inklusif. Proses penyadaran keluarga dengan ABK, oleh semua pihak sangatlah penting. Peranan ayah, ibu, adik, kakak, dan anggota keluarga lain, untuk membukakan pintu bagi ABK. Untuk mengenalkan kepada ABK indahnya dunia dan semua yang ada di dalamnya. Untuk meyakinkan bahwa kehidupan mereka sekarang dan yang akan dating akan dapat mereka lalui denga "baik-baik saja" contoh: Seorang anak yang mengalami sindrom autis dan tunagrahita dengan IQ di bawah 50. Untuk kemampuan membaca dan berhitung hanya meniru apa yang diucapkan guru/terapis. Sehingga, diajarkan pengenalan dengan berbagai cara tetapi belum juga ada kemajuan. Disarankan oleh tempat terapi anak ini dikembangkan bakat karena ia jenis autis hiperaktif tenaganya luar biasa. Orangtuanya mengarahkannya dengan memasukkan les drum untuk seni dan olahraga renang. Berkat kegigihan keluarganya, anak ini mendapat prstasi dibidang olahraga pada perlombaan renang pocada mendapatkan medali emas, perak, dan perunggu di provinsi jambi tahun 2012. 


\section{B. Lingkungan Sekitar Rumah}

Lingkungan sosial di sekitar rumah. Interaksi dengan tetangga perlu dibangun penyadaran tentang arti kehadiran ABK di dunia ini. Sikap orangtua dan anggota keluarga juga ikut menentukan aikap lingkungan/tetangga terhadap ABK. Keluarga yang bersikap wajar dalam memperlakukan ABK, tanpa ada perasaan canggung dan takut dicemooh, akan lebih dihargai oleh lingkungannya daripada keluarga yang selalu bersikap curiga dan takut dicemooh oleh tetangganya.

Anak-anak yang memiliki saudara kandung yang berkebutuhan khusus ini bukan hanya merasa bingung dengan apa yang dialami oleh saudaranya, namun juga ketakutan apakah ia juga akan mengalami hal yang sama, apakah mereka memiliki hubungan keluarga yang normal seperti keluarga-keluarga normal pada umumnya, siapa yang akan mengambil alih tanggung jawab terhadap saudaranya bila orang tua mereka meninggal dan rasa malu untuk menghadapi masyarakat sekitar.

Konflik siblings rivalry yang dialami oleh anak-anak yang memiliki saudara kandung dengan twice exceptionality biasanya lebih besar dari rata-rata anak lain karena sering kali saudara kandung melihat perlakuan orang tua yang berbeda terhadap dirinya dengan saudara yang memiliki kebutuhan khusus, sehingga memungkinkan terjadinya mislabeling.

\section{Lingkungan Sekitar sekolah}

Lingkungan social sekolah perlu kita siapkan untuk menerima kehadiran ABK, tumbuhkan empati yang menganggap $\mathrm{ABK}$ sebagai bagian warna-warni kehidupan mereka. Interaksi antar wali murid harus dibangun sebagai pola interaksi yang positif, saling ,mendkug dan 
memotivasi. Bukan interaksi negative yang terselubung dengan ungkapan dan tatapan penuh rasa kasihan denga ketidaksempurnaan ABK. Interaksi antar murid harus dibangun dengan pola interaksi yang saling menyayangi, menghargai dan juga berkompetisi sesuai dengan kemampuan mereka.

Hal ini sependapat dengan Tri Gunadi, bahwa ABK sangat membutuhkan dukungan, terutama dari orang-orang terdekatnya, yaitu peranan orangtua, pihak sekolah dan terapis. Pendidikan secara umum bertujuan untuk mengembangkan potensi peserta didik agar menjadi manusia yang beriman dan bertaqwa kepada Tuhan Yang Maha Esa, beraklak mulia, berilmu, cakap, kreatif, mandiri, dan menjadi warga Negara yang demikratis serta bertanggung jawab, termasuk program layanan pendidikan bagi ABK. 


\section{BAB VII}

\section{PENDIDIKAN INKLUSI: MODEL ALTERNATIF LAYANAN PENDIDIKAN ANAK BERKEBUTUHAN KHUSUS}

Menurut Pasal 15 UU No.20 tahun 2003 tentang Sisdiknas, bahwa jenis pendidikan bagi anak berkebutuhan khusus adalah pendidikan khusus. Pasal 32 (1) memberikan batasan bahwa pendidikan khusus merupakan pendidikan bagi peserta yang memiliki tingkat

Kesulitan dalam mengikuti proses pembelajaran karena kelainan fisik, emosional, mental, sosial, dan/atau memiliki potensi kecerdasan dan bakat istimewa. Teknis layanan pendidikan jenis pendidikan khusus untuk peserta didik yang berkelainan atau peserta didik yang memiliki kecerdasan luar biasa dapat diselenggarakan secara inklusif atau berupa satuan pendidikan khusus pada tingkat dasar dan menengah.

\section{A. Pengertian Pendidikan Inklusi}

Falsafah inklusif dikembangkan dari sistem pendidikan terintegrasi dengan tujuan untuk memastikan murid-murid dengan kebutuhan khusus mendapat akses pendidikan mereka dengan anak-anak istimewa di dalam ruang lingkup terkecil. Sejalan dengan impelementasi ini, semua lapisan masyarakat harus sadar bahwa anak-anak istimewa ini juga

bagian dari masyarakat.

Pendidikan inkulsif adalah sistem layanan pendidikan yang mesyaratkan anak berkebutuhan khusus belajar di sekolah-sekolah terdekat di kelas biasa bersama 
teman-teman seusianya (Sapon-Shevin dalan O'niel, 1994). Sekolah penyelenggara pendidikan inkulsif adalah sekolah yang menampung semua murid di kelas yang sama. Sekola ini menyediakan program pendidikan yang layak, menantang, tetapi disesuaikan dengan kemampuan dan kebutuhan setiap murid maupun bantuan dan dukungan yang dapat diberikan oleh para guru, agar anak-anak berhasil (Stainback, 1980).

Pendidikan inklusi adalah termasuk hal yang baru di Indonesia umunya. Ada beberapa pengertian mengenai pendidikan inkulusi, di antaranya pendidikan inklusi merupakan sebuah pendekatan yang berusaha mentransformasi system pendidikan dengan meniadakan hambatan-hambatan yang dapat menghalangi setiap siswa untuk berpartisipasi penuh dalam pendidikan. Hambatan yang ada bias terkait dengan masalah etnik, gender, status sosial, kemiskinan, dan lain-lain. Dengan kata lain pendidikan inklusi adalah layanan pendidikan anak berkebutuhan khusus yang dididik bersama anak-anak lainnya (normal) untuk mengoptimalkan potensi yang dimilikinya. Menurut Budi S. pendidikan inklusi diselenggarakan berdasarkan semangat untuk membangun system masyrakat inklusif, yakni sebuah tatanan kemasyarakatan yang saling menghargai dan menghormati keberagaman. Dengan demikian, penyelenggara pendidikan masyarakat iklusif, yakni sebuah tatanan kemasyarakatan yang saling menghargai dan menghormati keragaman.

Mereduksi filosofis inklusif di atas, maka pendidikan inklusi dikembangkan berdasarkan keyakinan fundamental bahwa setiap individu dapat belajar, berkembang, tumbuh, dan bekerjasama dengan semua orang yang memiliki latar belakang yang berbeda di sekolah, lingkungan kerja, dan masyarakat. Pendidikan inklusi adalah wujud nayata komitmen penyediaan 
kesempatan belajar bagi semua anak, remaja, dengan fokus pada individu yang tergolog minoritas, terpinggirkan dan tidak terperhatikan.

Sebagian individu yang tergolong minoritas, terpinggirkan dan belum terperhatikan adalah mereka yang memiliki kebutuhan khusus seperti individu yang mengalami hambatan fisik, mental-intelektual, sosial, emosi, berbakat, kesulitan belajar, autism, gangguan konsentrasi dan hiperaktif, dan sebaginya. Kelompok anak berkebutuhan khusus (ABK) lainnya yang tidak diperhatikan seperti anak jalanan dan pekerja, anak yang beasal dari populasi terpencil atau yang berpindah-pindah, anak dari kelompok minoritas, lingusitik atau budaya, dan anak-anak dari kelompok kurang beruntung atau dimarginalkan.

Pendidikan inklusif selayaknya merangkul mereka yang termarginalkan untuk dapat mengenyam pendidikan yang berkulitas. Pendidikan inklusif membuat sesuatu yang tidak terlihat, yang tidak terperhatikan, yang tidak terlayani menjadi berharga dan tersisih menjadi dapat berpartisipasi. Pendidikan inklusif mencoba memastikan bahwa semua siswa mendapatkan hak dan memastikan semua siswa memperoleh pendidikan dengan kualitas yang baik (Sheaffer, 2005).

Selanjutnya, para ahli mencoba membuat konsep defenitif tentang pendidikan inklusif. Staub dan Peck dalam dinas pendidikan (2004) mengeukakan bahwa pendidikan inklusif adalah penempatan anak berkeainan tingkat ringan, sedang, dan berat secara penuh di kelas reguler. SaponShevi dalam Sunardi (2002) menyatakan bahwa pendidikan inklusif merupakan system pelayanan pendidikan kebutuhan khusus yang mempersyaratkan agar semua anak berkebutuhan khusus dilayani di sekolah-sekolah terdekat di kelas biasa bersama teman-teman sebayanya. Untuk itu 
ditekankan adanya restruktuisasi di sekolah sehingga menjadi komunitas yang mendukung pemenuhan kebutuhan khusus setiap anak, artinya seumber dan dukungan dari semua guru dan siswa harus diperkaya.

Defenisi di atas menunjukkan bahwa pendidikan inklusif menempatkan semua anak (anak-anak pada umumnya dan anak berkebutuhan khusus) dalam satu komunitas. Menempatkan anak berkebutuhan khusus di kelas reguler bersama dengan anak-anak pada umumnya merupakan bagian dari upaya untuk tidak memisahkan mereka dari masyarakat normal.

Secara konsep defenisi pendidikan inklusif di atas telah menggeser praktik pendidikan yang terpisah. Pendidikan bagi anak-anak kebutuhan khusus, sementara ini lebih dominan dilakukan dalam setting persekolah yang terpisah seperti untuk anak tunanetra (SLB A), SLB B untuk anak tunarungu wicara, SLB C untuk anak gangguan mental, SLB D untuk anak tunadaksa dan seterusnya. Mereka (ABK) benar-benar dipisahkan. Impelemntasi pendidikan inklusif menuntut berbagai hal demi tercapainya pendidikan yang ramah berkaitan kebijakan, kurikulum nasional, adanya kerjasama lintas sektoral, adaptasi lingkungan, ekonomi hingga kesadaran masyarakat untuk memahami keberagaman dan keanekaragaman.

\section{B. Dasar Hukum}

\section{Landasan Yuridis}

a. Konvensi PBB tentang Hak Anak Tahun 1989

b. Deklarasi Pendidikian untuk Semua di Thailand Tahun 1990

c. Kesepakatan Salamanka tentang Pendidikan Inklusi Tahun 1994

d. UU No.4 tentang Penyandang Cacat Tahun 1997 
e. UU No.23 tentang Perlindungan Hak Anak Tahun 2003

f. PP No.19 tetang Standar Pendidikan Nasional Tahun 2004

g. Deklarasi Bandung tentang Menuju Pendidikan Inklusi Tahun2004

Pendidikan Inklusif berdasarkan PP No.17 Tahun 2010:

- (6) SD/MI atau bentuk lain yang sederajat wajib menyediakan akses bagi peserta didik berkelainan.

- (3) SMP/MTs atau bentuk lain yang sederajat wajib menyediakan akses bagi peserta didik berkelinan.

- Pasal 81: (6) SMA, MA, SMK, MAK, atau bentuk lain yang sederajat wajib menyediakan akses bagi peserta didik berkelainan.

- Pasal 81: (7) satuan pendidikan SMA, MA, SMK, MAK, atau bentuk lain yang sederajat memberikan bantuan penyesuaian akademik, social, dan/atau mental yang diperlukan oleh peserta didik berkelainan dan peserta didik pindahan dari satuan pendidikan formal lain atau jalur pendidikan lain.

h. Rekomendasi Bukittinggi (2005), bahwa pendidikan yang inklusif dan ramah terhadap anak seyogyanya dipandang sebagai:

- Sebuah pendekatan terhadap peningkatan kualitas sekolah secara menyeluruh yang akan menjamin bahwa strategi nasional untuk "pendidikan untuk semua" adalah benar-benar untuk semua. 
- Sebuah cara untuk menjamin bahwa semua anak memperoleh pdndidikan dan pemeliharaan yang berkualitas di dalam komunitas tempat tinggalnya sebagai bagian dari program-program untuk perkembangan usia dini anak, pra sekolah, pendidikan dasar dan menengah, terutama mereka yang pada saat ini masih belum diberi kesempatan untuk memperoleh pendidikan di sekolah umum atau masih rentan terhadap marginalisasi dan ekslusi.

- Sebuah kontribusi terhadap pengembangan masyarakat yang menghargai dan menghormati perbedaan individu semua warga.

Kalau kita mencermati lebih teliti, landasan spiritual maupun landasan yuridis tersebut telah memberikan dasar hokum yang jelas tentang bagaimana peyelenggaraan pendidikan inklusi yang memang merupakan sebuah kebutuhan yang tidak dapat ditunda-tunda lagi. Dan, segera direalisasikan.

\section{Tujuan Pendidikan Inklusi}

Pendekatan untuk mencari cara bagaimana mengubah system pendidikan guna menghilangkan hambatan yang menghalangi siswa untuk terlibat secara penduh dalam pendidikan

Dari persoalan informasinya yang masih sangat minim diperoleh, baik mengenai pentignya PAUD bagi ABK ditambah dengan jumlah sekolahnyapun yang masih dalam hitungan jari, memang pada akhirnya belum bias memfasilitasi seluruh kebutuhan dari anak berkebutuhan khusus, terutama untuk pendidikan usia dini. 
Pentingnya PAUD bagi ABK adalah semakin cepatnya ABK mendapatk pendidikan maka semakin cepat pula "delay" waktu yang terentang antara kesetaraan ABK dan "anak normal" semakin kecil. Sehingga ABK nantinya bisa mengembangkan intelektual emosi, dan social semaksimal mungkin. Pendidikan merupakan kebutuhan dasar setiap manusia untuk menjamin keberlangsungan hidupnya agar lebih bermartabat. Karena itu, negara memiliki kewajiban untuk memberikan pelayanan pendidikan yang bermutu kepada setiap warga tanpa terkecuali termasuk mereka yang memiliki perbedaan dalam kemampuan (difabel) seperti yang tertuang pada UUD 1945 Pasal 31 (1). Namun sayangnya system pendidikan Indonesia belum mengakomodasi keberagaman sehingga menyebabkan munculnya segmentasi lembaga pendidikan yang berdasar pada perbedaan agama, etnis, dan bahkan perbedaan kemampuan baik fisik maupun mental yang dimiliki siswa. Jelas segmentasi lembaga pendidikan ini telah menghambat para siswa untuk dapat belajar menghormati realitas keberagaman dalam masayarakat.

Selama ini anak-anak yang memiliki perbedaan kemampuan (difabel) disediakan fasilitas pendidikan khusus disesuaikan dengan derajat dan jenis difabelnya yang disebut dengan sekolah luar biasa (SLB). Secara tidak disadari system pendidikan SLB telah membangun tembok eksklusivisme bagi anak-anak yang berkebutuhan khusus. Tembok ekslusivisme tersebut selama ini tidak disadari telah menghambat peruses saling mengenal antara anakanak difabel dengan anak-anak non difabel. Akibatnya dalam interaksi sosial dimasyarakat kelompok difabel menjadi komunitas yang tereliminasi dari dunia kehidupan kelompok difabel. Smentara kelompok difabel sendiri merasa keberadaanya bukan menjad bagian integral dari kehidupan masyarakat di sekitarnya. 
Seiring dengan perkembangannya tuntutan kelompok difabel dalam menyarakan hak, maka kemudian muncul konsep pendidikan inklusi. Salah satu kesepakatan internasional yang mendorong terwujudnya system pendidikan inklusi adalah Convention on the Right of Person with Disabilities and Optonal Protocol yang disahkan pada maret 2007. Pada Pasal 24 dalam konverensi ini disebutkan bahwa setiap Negara berkewajiban untuk menyelenggarakan sistem pendidikan inklusi di setiap tingkatan pendidikan. Adapun salah satu tujuannya kehidupan adalah untuk untuk mendorong terwujudnya partisipasi penuh difabel di dalam kehidupan masyarakat. Namun, dalam peraktiknya sistem pendidikan inklusi di Indonesia masih menyisakan persoalan tarik ulur antaea pihak pemerintah dan praktisi pendidikan, dalam hal ini para guru.

\section{Manfaat PAUD Inklusi}

Meski sampai saat ini PAUD inklusi masih terus melakukan perbaikan dalam berbagai aspek. Namun dilihat dari sisi idelanyan PAUD inklusi merupakan pendidikan yang ideal bagi anak ABK maupun non-ABK. Pendidikan sangat mendukung terhadap perkembangan anak berkebutuhan khusus, mereka dapat belajar dari interaksi spontan teman-teman sebayannya terutama dari aspek sosial dan emosional. Adapun bagi anak yang tidak berkebutuhan khusus, memberi peluang kepada mereka untuk belajar berempati, bersikap membantu, dan memiliki kepedulian. Di samping itu, bukti lain yang ada mereka yang tanpa berkebutuhan khusus memiliki prestasi yang baik tanpa merasa terganggu sedikitpun. 


\section{E. Gagasan PAUD Inklusi}

PAUD inklusi PAUD yang mengoordinasi mengintegrasikan anak PAUD dan anak penyandang cacat dalam program yang sama, awal dari mempersiapkan pendidikan bagi anak penyandang cacat yang mempunyai kemampuan di atas anak difabel lainnya, baik tingkah laku adalah pentingnya pendidikan inkulusi, tidak hanya memenuhi target pendidikan untuk semua tetapi juga pendidikan dasar. Hal ini lebih banyak keuntungannya, tidak hanya memenuhi hak-hak anak tetapi lebih penting lagi bagi kesejahteraan anak, karena pendidikan inklusi mulai dengan merealisasikan perubahan keyakinan masyarakat yang terkandung akan menjadi bagian dari keseluruhan. Dengan demikian, anak akan merasa tenang, percaya diri, merasa dihargai, dilindungi, disayangi, bahagia dan bertanggung jawab. Inklusi terjadi pada semua lingkugan sosial anak, pada keluarga, kelompok teman sebaya, sekolah, institusi-institusi kemasyarakatan lainnya.

Masyarakat yang melaksanakan pendidikan inklusi berkeyakinan bahwa hidup dan belajar bersama adalah cara hidup (way of life) yang terbaik, yang menguntungkan semua orang, karena tipe pendidikan ini dapat menerima dan meres

pon setiap kebutuhan individual anak. Dengan demikian, sekolah atau menjadi suatu lingkungan belajar yang ramah bagi anak-anak. Pendidikan inklusi adalah adalah sebuah system pendidikan yang memungkinkan setaiap anak penuh berpartisipasi dalam kegiatan tanpa mempertimbangkan kecacatan atau karakteristik lainnya. Di samping itu, pendidikan inklusi juga melibatkan orangtua dalam cara yang berarti dalam berbagai kegiatan pendidikan, terutama dalam proses perencanaan, sedang 
dalam belajar mengajar pendekatan guru berpusat pada anak, dan bersifat individual.

\section{F. Implementasi PAUD Inklusif di Lapangan}

Indonesia menuju pendidikan inklusi secara formal dideklarasikan pada tanggal 11 Agustus 2004 di Bandung, denggan harapan dapat menggalang sekolah regular untuk mempersiapkan pendidikan bagi semua anak termasuk penyandang cacat. Setiap penyandang cacat berhak memperoleh pendidikan pada semua sector, jalur, jenis, dan jenjang pendidikan (Pasal 6 ayat 1). Setaiap penyandang cacat memiliki hak yang sama untuk menumbuhkembangkan bakat, kemampuan dan kehidupan sosialnya, terutama bagi penyandang cacat dalam lingkungan keluarga dan masyarakat (Pasal 6 ayat 6 UU RI No.4 Tahun 1997 tentang Penyandang Cacat).

Untuk mengarahkan ABK memperoleh PAUD pada lembaga umum (bukan TKLB) ternyata hamper tidak ada yang mau menerima ABK. Dengan alas an yang klasik, mereka tidak mempunyai kemampuan untuk bisa menerima ABK dan menyarankan untuk ke lembaga/sekolah khusus, alasan lainnya mereka khawatir anak ABK dapat mengganggu anak-anak lain, dan merepotkan.

Kasus serupa dapat terjadi di beberapa daerah seperti Jakarta, Bandung, semarang, Yogyakarta, dan Balikpapan. Walaupun sebenarnya, jika melihat kota-kota tersebut sudah termasuk dalam kota provinsi yang seharusnya memiliki lembaga yang memfasilitasi. Sehingga timbullah sebuah pertanyaan, di kota besar saja ABK tidak/belum bias memperoleh PAUD yang sudah seharusnya menjadi hak mereka. 
Dengan adanya masalah di atas, sebagai pengelola PAUD ataupun guru merasa empati dan mempunyai tanggung jawab atas pendidikan anak-anak seusia PAUD, baik mereka yang dalam kondisi apapun sehingga tidak ada perbedaan bagi layanan semua anak dan mencerdasakan anak-anak usia dini. Pemahaman ini mempunyai landasan hokum sesuai dengan dasar-dasar hokum menurut PP No.17 2010 di atas. Sebagai guru/pengelola PAUD, belajar memahami arti keberasamaan untuk anak didik dan member motivasi kepada anak didik non ABK untuk menerima adanya keberagaman dalam dalam pembelajaran hal ini sebagi proses pengembangan sosialisasi bagi anak.. untuk menerima akan ABK, sebagai pengelola/guru member peluang mereka mengikuti pelajaran. Dengan waktu di kelas tidak begitu lama dan bertahap. Apabila anak sudah bias dengan kondisi kelas dan mengikuti aturan maka baru ditambah waktunya. Dan, berikan pemahaman dengan orangtua, apabila anak mengalami masa bosan, anak boleh di luar kelas sehingga di dalam kelas pembelajaran tidak terganggu. Dan orangtua atau guru pendamping khusus siap menjelaskan dan mengarahkan bila anak tidak mengerti instrukesi guru di depan kelas.

Mengelola PAUD inklusif, dituntut untuk memiliki kepekaan yang super terhadap elemen-elemen yang berpengaruh terhadap proses tumbuh kembang ABK. Elemen pendukung tersebut antara lain:

1. Keluarga ABK: Ayah, ibu serta anggota keluarga lainnya.

2. Lingkungan Biotik : Lingkungan rumah dan lingkungan sekolah

Lingkungan Abiotik : Lingkungan sekolah dan lingkungan rumah

Tenaga Pendidik : Kepala PAUD, guru pendamping khusus, guru 


\section{BAB VIII}

\section{PROGRAM PEMBELAJARAN KHUSUS UNTUK ANAK BERKEBUTUHAN KHUSUS}

Anak berkebutuhan khusus dengan segala karakteristik dan hambatan yang dimiliki, ABK memerlukan bentuk pelayanan pendidikan khsusus yang disesuaikan dengan kemampuan dan potensi mereka khususnya mengenai kebutuhan dan kemampuannya dalam belajar di sekolah.

\section{A. Program Khusus Pembelajaran ABK \\ Menurut Pasal 129 ayat:}

(1) Pendidikan khusus bagi peserta didik berkelainan berfungsi memberikan pelayanan bagi peserta didik yang memiliki kesulitan dalam mengikuti proses pembelajaran, karena kelainan fisik, emosional, mental, intelektuan, dan/atau sosial.

(2) Pendidikan khusus bagi peserta didik berkelainan bertujuan untuk mengembangkan potensi peserta didik secara optimal sesuai dengan kemampuannya.

Potensi sumberdaya manusia merupakan asset nasional sekaligus modal dasar pembangunan bangsa. Potensi ini hanya dapat digali ddan dikembangkan serta dipupuk secara efektif melalui strategi pendidikan dan pembelajaran yang terarah dan terpadu, yang dikelola secara serasi dan seimbang dengan memerhatikan pengembangan potensi peserta didik secara ituh dan optimal. 
Anak berkebutuhan khusus (special need) merupakan anak yang terlahir ataupun tumbuh dan berkembang dengan berbagai kekurangan, baik fisik, mental, maupun intelegensi. Salah satu kelompok yang paling terekslusi dalam memperoleh pendidikan adalah siswa penyandang cacat. Tetapi ini bukanlah kelompok yang homogen. Sekolah dan layanan pendidikan lainnya harus flesibel dan akomodatif untuk memenuhi keberagaman kebutuhan siswa. Mereka juga diharapkan dapat mencari anak-anak yang belum mendapatkan pendidikan. Gangguan tumbuh kembang anak dapat dialami oleh anak usia pra sekolah dan juga anak sekolah. Jenis gangguan tumbuh kembang pada masa pra sekolah adalah gangguan pemusatan perhatian dan hiperativitas (GPPH), gangguan spectrum autistic, dan gangguan epilepsi.

Pasal 29 ayat:

(3) Peserta didik yang berkelainan terdiri atas peserta didik yang:

a. Tunanetra

b. Tunarungu

c. Tunawicara

d. Tunagrahita

e. Tunadaksa

f. Tunalaras

g. Berkesulitan belajar

h. Lamban belajar

i. Autis

j. Memiliki gangguan motorik

k. Menjadi korban penyalagunaan narkoba, obat terlarang, dan zat aktif lainnya

l. Memiliki kelainan lain. 
(4) Kelainan sebagaiman dimaksud pada pasal (3) dapat juga berwujud gabungan dari dua atau lebih jenis kelainan, yang diebut tunaganda.

Beberapa Jenis Layanan Pendidkan PAUD Inklusif antara lain:

Direktorat PLB menjelaskan tentang penempatan anak berkelainan di sekolah inklusi dapat dilakukan dengan berbagai model sebagai berikut:

1. Kelas regular (inklusi penuh). Anak berkelainan belajar bersama anak lain (normal) sepanjang hari di kelas regular dengan menggunakan kurikulum yang sama.

2. Kelas regular dengan cluster. Anak berkelainan belajar bersama anak lain (normal) di kelas regular dalam kelompok khusus.

3. Kelas regular dengan pull out. Anak berkelainan belajar bersama anak lain (normal) di kelas regular namun dalam waktu-waktu tertentu ditarik dari kelas regular ke ruang sumber untuk belajar dengan guru pemdimbing khusus.

4. Kelas regular dengan cluster dan pull out. Anak berkelaian belajar bersama anak lain (normal) di kelas regular dalam kelompok khusus, dan waktuwaktu tertentu ditarik dari kelas regular ke ruang sumber untuk belajar dengan guru pembimbing khusus.

5. Kelas khusus dengan berbagai pengintegrasian. Anak berkelainan belajar di dalam kelas khusus pada sekolah reguler, namun dalam bidangbidang tertentu dapat dapar belajar bersama anak lain (normal) di kelas reguler.

6. Kelas khusus penuh. Anak berkelainan belajar di dalam kelas khusus pada sekolah reguler. 
Model pelayanan pendidikan bagi anak dengan gangguan fisik dan intelegensi dibagi menjadi dua, yakni sekolah khusus dan sekolah terpadu atau inklusi.

Sekolah ini diperuntukkan bagi mereka yang mengalami gangguan berat, ringan, dan masalah penyerta intelektual seperti retradisi mental maupun masalah kesulitan gerak dan emosi. Sekolah inklusi ini diperuntukkan bagi anak tunadaksa dengan kondisi ringan dan tidak mengalami retradisi mental. Anak tunadaksa golongan tersebut akan lebih baik bila disatukan dengan anak normal lainnya sedini mungkin. Hal ini dilakukan karena umumnya mereka telah mampu mengatasi masalah fisik, intelektual, dan emosionalnya.

Berikut disampaikan uraian secara terinci tentang jenis Program Layanan Pendidikan ABK, Yaitu:

1. Kelas Khusus

Yang dimaksud kelas khusus adalah kelas yang diikuti oleh anak berkebutuhan khusus (GPK) menggunakan pendampingan penuh (satu guru satu murid) serta berada di ruanga khusus yang berada dalam lingkungan sekolah reguler.

Ada tiga model yaitu:

a. Bagi ABK yang memiliki perilaku. Model ini satu siswa dibimbing oleh satu guru di dalam ruangan khusus.

b. ABK belajar dalam kelas khusus bersama ABK lainnya dengan tetap mendapatkan bimbingan penuh (satu guru satu siswa)

c. ABK yang sudah mampu belajar dengan pola semi-klsikal dibimbing oleh (GPK) utama, 
akan tetapi masih tetap didampingi oleh guru pembimbing yang berfungsi sebagai Shadow.

2. Kelas Pra-klasikal

Beberapa ABK dengan kemampuannya yang hamper sama, belajar dalam satu rombongan belajar yang dibimbing oleh BPK dalam ruangan sumber bersama dengan rombongan belajar pada bidang tertentu, seperti bermain di luar kelas, sentra bahan alam, sentra seni, sentra persiapan, sentra balok, sentra agama untuk sentra peran (peran GPK dibutuhkan sewaktuwaktu).

3. Kelas Remedi

Kelas remedy adalah pengulangan pembelajarn tambahan yang berupa terapi yaitu terapi wicara, okupasi, pedagogi, komunikasi, dan lain-lain.

4. Kelas Pendampingan

ABK belajar bersama anak lain (normal) di kelas reguler sepanjang hari. Mereka dibimbing oleh guru utama sebagai penyaji materi, namun dalam kelompok ABK didampingi oleh GPK sebagai shadow.

5. Kelas Pengayaan

Adapun yang dimaksud kelas penganyaan adalah siswa dengan kemampuan lain (normal/biasa) namun dalam bidang studi tertentu untuk kecerdasan dan keterbatasannya siswa ditarik ke ruang sumber dibimbing oleh GPK.

6. Kelas Inklusi Penuh

Yang dimaksud kelas inklusi penuh adalah ABK belajar sepanjang hari di kelas reguler menggunakan beban kurikulum yang sama tanpa pendampingan. 
Meningkatkan perluasan dan pemerataan kelas layanan PAUD melalui penyelenggaraan PAUD yang murah, mudah, tetapi bermutu. Meningkatkan kesadaran, kemampuan dan partisipasi aktif masyarakat dalam memberikan layanan PAUD.

Memberikan layanan yang prima (efektif, efisien, akuntabel dan transparan kepada masyarakat di bidang PAUD. Perlu ditelaah kembali apakah hal tersebut juga menjadi hak dari anak berkebutuhan khusus?

Baik anak "normal" maupun berkebutuhan khusus, mereka sama-sama mengalami masa keemasan yang disebut "golden age" dan mereka juga mempunyai hak yang sama dalam memperoleh pendidikan sejak dini. Dalam masyarakat awam, saat ini seperti sudah menjadi "pakem" bahwa anak usia sekian masuk playgroup, usia sekian masuk TK, usia sekian masuk SD, dan selanjutnya. Namun untuk anak $A B K$ sangat minim sekolah untuk $A B K$, sehingga perlu mendapat perhatian serius.

\section{B. Kurikulum PAUD Inklusi} berikut:

Kurikulum yang digunakan terbagi sebagai

1. Bagi siswa dengan layanan khusus menggunakan kurikulum modifikasi total dengan mengacu pada kurikulum TK luar biasa (TKLB) dan kurikulum reguler (sekolah biasa).

2. Bagi siswa dengan layanan pra-klasikal menggunakan kurikulum reguler yang dimodifikasi (baik modifikasi waktu maupun materi/muatan). 
3. Bagi siswa dengan layanan remedy, pendampingan dan inklusi penuh menggunakan kurikulum reguler (umum).

4. Bagi siswa dengan layanan pengayaan menggunakan kurikulum reguler yang dikembangkan. Metode pembelajaran yang diterapkan sama dengan layanan kelas reguler, yaitu metode ceramah, penugasan maupun privat, yang membedakan adalah adanya guru pendamping yang keberadaannya menyesuaikan dengan tingkat kebutuhan siswa.

Model pendidikan inklusi di negeri ini belum beranjak dari tahap pencarian bentuk dan masih jauh untuk diwujudkan secara ideal. Kenyataan tersebut sangat jauh berbeda dengan Singapura yang telah menetapkan sekolah inklusi sejak anak berusia dini. Demikian disampaikan Mulyono Abdurrahma dari PPs UNJ dalam seminar tentang "Sekolah Inklusi Ramah untuk Semua. Dijelaskan Mulyono, jika menengok jumlah penduduk dengan perbandingan perhitungan data yang dikeluarkan WHO, dimana 550 juta penduduk dunia adalah berkebutuhan khusus, dan 80\% tinggal di Negara berkembang termasuk Indonesia. Semestinya pemerintah, lembaga, lembaga pendidikan, atau pihak terkait negeri ini sudah dalam posisi diaga I.

Pembicara lain akademisi dari UNJ, Tatok Bintaro mengungkapkan data peserta didik berkebutuhan khusus tahun 2000 ada;ah kurang lebih 1,8 juta. Dari jumlah tersebut, baru 45.000 orang atau 2,5\% yang mendapat kayanan pendidikan, itupun dilayani oleh SLB. Padahal kemampuan pemrintah untuk menambah SLB sangat terbatas. Sementara implementasi pendidikan inklusi di Indonesia juga masih jauh. Hal ini karena cara pandang dan pemahaman tentang pendidikan inklusi yang masih kuran 
yang, baik di masyarakat maupun di tingkat legislative. Bagi pemeritah, seperti diungkapkan Direktorat Pembinaan Sekolah Luar Biasa Depdiknas, Eko Djatmiko, bebrbagi kebijakan dalam mengembangkan model inklusi dalam realisasinya selalu membawa masalah. Semua ini terjadi karena pemahaman konsep dasar sekolah inklusi yang masih terbatas dan variatif, belum adanya data sekolah dan siswa inklusi yang akurat, kurangnya tenaga pendidik yang kompeten sebagi guru pendamping, belum adanya system penilaian di luar SOP yang telah ada, anggota pokja sekolah inklusi yang belum melibatkan unsure professional, serta belum adanya permendiknas tentang sekolah inklusi.

Dengan mengetahui gejala dan melakukan penanganan dengan tepat, orantua dapat mengembangkan potensi yang ada dalam diri anak. Anak pun dapat tumbuh dan berkembang lebih dari yang dibayangkan. Anak berkebutuhan khusus juga bisa menjadi orang yang sukses. Bahkan, kesuksesan mereka dapat melebihi kesuksesan orang terlahir dengan kondisi normal.

Penanganan anak berkebutuhan khsusus sangat penting dilakukan. Semakin dini penanganan, semakin rendah resiko seorang anak terkena gangguan. Dalam menangani $\mathrm{ABK}$, peran keluarga terutama orangtua, pihak sekolah, dan lingkungan di sekitar sangat diperlukan. 


\section{BAB IX}

\section{KONSEP LAYANAN PENDIDIKAN BAGI ANAK BERKEBUTUHAN KHUSUS}

\section{A. Identifikasi Layanan Pendidikan Anak Berkebutuhan Khsusus}

Pendidik bagi anak berkebutuhn khusus seharusnya dapat memberikan layanan pendidikan pada setiap anak berkebutuhan khusus. Realitasnya masih banyak penddik yang belum memahami tentang ABK. Hal ini terpengaruh dalam memberikan terhadap anak tersebut. Agar pendidik dapat memebrikan layanan secara maksimal terhadap anak berkebutuhan khusus, maka berikut langkah-langkah yang diperlukan antara lain:

\section{Langkah Identifikasi}

Langkah identifikasi adalah usaha untuk mengenali atau menemukan ABK sesuai dengan ciri-ciri yang ada dengan mengenali kondisi dan perkembangan anak melalui kegiatan sehari-hari. Selain mengamati perlu juga mewawancara orang tuanya ataupun keluarganya yang dapat memberikan informasi yang bermanfaat untuk kepentingan ABK tersebut.

a. Pada langkah identifikasi ini akan mengungkap ciriciri atau karakteritik pada ABK diantaranya:

1) Kondisi fisik, yang mencakup keadaan fisik secara umum dan kondisi fisik baik secara organik maupun fungsional, maksudya adalah apakah kondisi yang ada memoengaruhi fungsi yang lain. 
2) Kemampuan inteletual, yaitu kemmapuan anak dalam menerima pelajaran, mengerjakan tugastugas aakdemik di sekolah.

3) Kemampuan komunikasi, yaitu kesanggupan seseorang anak dalam memahami dan mengekspresikan gagasannya dalam berinteraksi terhadap lingkungan sekitarnya, baik secara lisan maupun tulisan.

4) Sosial emosional, kegiatan/aktivitas yang dilakukan seseorang anak dalam kegiatan interaksinya dengan teman atau gurunya yang dapat dilihat melalui pergaulannya baik di lingkungan sekolah maupun lingkungan lainnya.

b. Teknik identifikasi yang dapat dilakukan antara lain:

1) Teknik observasi, merupakan teknik untuk melakukan identifikasi ABK dengan cara mengamati kondisi keberadaan pada saat di dalam ataupun di luar kelas.

2) Teknik wawancara, untuk memperoleh informasi mengenai keberadaan ABK dalam upaya melakukan identifikasi.

3) Teknik testing, teknik penilaian yang berupa tugas atau serangkaian kegiatan yang harus dikerjakan ABK dan akan menghasilkan suatu nilai tentang kemampuan atau perilaku anak sehingga dapat diketahui tentang apakah seseorang anak berkebutuhan khsusus atau tidak.

4) Tes Psikologi, mengetahui tingkat akurasi hasil tes. Sehingga dapat diperediksi apa-apa yang akan terjadi dalam belajar anak pada tahap berikutnya. Serta dapat memperediksi tingkat kecerdasan, bakat, minat dan kepribadian anak. 
1. Langkah Asesmen

Asesmen sebagai upaya untuk memperoleh informasi yang relevan guna membantu seseorang dalam membuat keputusan.

a. Tujuan asesmen antara lain:

1) Melihat kemampuan anak pada setiap aspek.

2) Untuk mengelompokkan anak sesuai dengan karakteristiknya dan penetuan programnya.

3) Untuk menentukan arah dan tujuan pendidikan yang disesuaikan dengan berat/ringanya kelainan yang disandang ABK

4) Untuk pengembangan program pendidikan yang dirancang khusus secara individu untuk ABK

5) Untuk penentuan strategi, lingkungan belajar, dan penilaian pembelajaran

6) Untuk memantau perkembangan belajar siswa

b. Langkah pelaksanaan asesmen

1) Menentukan cakupan dan tahapan ketrampilan yang akan diajarkan guru. Guru sebelum mengadakan evaluasi sebaiknya memahami dulu tahapan kompetensi pembelajaran siswa. Untuk mengetahui ketrampilan apa yang sudah dikuasai oleh anak

2) Menentukan perilaku yang akan diakses

3) Memilih aktifitas penilaian

4) Pengorganisasian alat evaluasi

5) Pencatatan kinerja siswa, terutama pemantauan kemajuan belajar siswa

6) Penentuan pembelajaran untuk jangka pendek dan panjang secara spesifik, tetapi harus tetap berkontribusi dalam jangka panjang. 
c. Teknik pelaksanan asesmen

1) Observasi, untuk mengamati aktivitas belajar siswa; cara belajar, perilaku dan kompetensi yang dicapai siswa

2) Tes formal, dengan mengacu pada bentuk tes acuan norma atau acuan tolak ukur yang ditetapkan

3) Tes informasi untuk mengetahui kompetensi khusus pada anak

4) Wawancara, untuk memperoleh informasi dari berbagai sumber data, diantaranya orang tua, siswa, keluarga, guru, teman sepermainan dan sebagainya.

\section{B. Hal-hal yang Berkaitan dengan Layanan Pendidikan Terhadap Anak yang Berkebutuhan Khusus}

Sosialisasi bukannya cukup seorang anak autistik berada dalam kumpulan anak-anak lain melainkan anak tersebut hanya bermain sendiri, tidak dapat bermain bersama-sama dengan anak lain, tidak dapat mengikuti aktivitas kelompok, atau malah hanya mengganggu atau menjadi sumber gangguan kelompok atau aktivitas kelompok. Sosialisasi adalah interaksi timbale balik dengan lingkungan anak-anak sebaya dan orang lain yang ada, serta berbagai hal yang terdapat dalam lingkunga tersebut (people, places, events).

Tujuan sosialisasi di sekolah adalah menggeneralisasikan kemampuan/keterampilan social yang dipelajarai secara one-to-one pada situasi belajar di teaching-room, ke lingkungan dengan anak-anak sebaya yang telah berkembang sesuai umurnya. Selain itu juga mempelajari kemampuan/keterampilan sosial yang baru 
sehingga anak kemudian dapat tumbuh dan berkembang bersama lingkungannya untuk menuju hidup mandiri.

Selain itu, tujuan anak di sekolahkan adalah menggneralisasi kemampuan akademik yang telah dipelajari pada situasi belajar terstruktur (one-one-one) ke lingkungan instruksinya diberikan secara umum atau kelompok anak-anak yang telah berkembang sesuai umurnya. Selain itu juga mempelajari kemampuan akademik yang baru.

Autism dalam Diagnostic and Statistical Manual of Mental Disoder R-IV merupakan salah satu dari lima jenis gangguan di bawah paying PDD (Pervasive Development Disorder) di luar ADHD (Attention Deficit Disorder). Gangguan perkembangan perpasif (PDD) adalah istilah yang dipakai untuk menggambarkan beberapa kelompok gangguan perkembagan di bawah (umbrella term), yaitu:

1. Autistic Disorder (Autism). Muncul sebelum usia tiga tahun dan ditunjukkan adanya hambatan dalam interaksi sosial, komunikasi dan kemampuan bermain secara imajinatif serta adanya perilaku streotip pada minat dan aktivitas.

2. Aspeger's Syndrome. Hambatan perkembangan interaksi sosial dan adanya minat dan aktivitas yang terbatas, secara umum tidak menunjukkan keterlambatan bahasa dan bicara, serta memiliki tingkat intelegensia rata-rata hingga di atas rata-rata.

3. Pervasive Developmental Disorder-Not Otherwise Specified (PDD-NOS). Merujuk pada istilah atypical autism, diagonis PDD-NOS berlaku bila seorang anak tidak menunjukkan keseluruhan kertiteria pada diagnostis tertentu (autism, asperger, atau rett syndrome).

4. Rett's Syndrome. Lebih sering terjadi pada anak perempuan dan jarang terjadi pada anak laki-laki. 
Sempat mengalami perkembangan yang normal kemudian terjadi kemunduran/kehilangan kemampuan fungsional tangan yang digantikan dengan gerakan-gerakan tangan yang berulang-ulang pada rentang usia 1-4 tahun.

5. Chilhood Disintegrative Disorder (CDD). Menunjukkan perkembangan yang normal selama dua tahun pertama usia perkemangan kemudian tiba-tiba kehilangan kemampuan-kemampuan yang telah dicapai sebelumnya.

Diagnosis Pervasive Developmental Disorder-Not Otherwise Specified (PDD-NOS) umumnya dipakai di Amerika Serikat untuk menjelaskan adanya beberapa karakteristik autism pada seseorang (Howlin, 1998:79). National Information Center for Children and Youth with Disabilities (NICHCY) di Amerika menyatakan, bahwa autism dan PDD-NOS adalah gangguan perkembangan yang cenderung memiliki karakteristik serupa dan gejalanya muncul sebelum usia tiga tahun. Keduanya merupakan gangguan yang bersifat neurologis yang mempengaruhi kemampuan berkomunikasi, pemahaman bahasa, bermain, dan kemampuan berhubungan dengan orang lain. Ketidakmampuan beradaptasi pada perubahan dan adanya respon-respon yang tidak wajar pengalaman sensoris sering kali juga dihubungkan pada gejala autism.

Beberapa atau keseluruhan karakteristik yang disebutkan berikut ini dapat diamati pada penyandang autism beserta spektrumnya, baik dengan kondisi yang teringan hingga terberat sekalipun.

1. Hambatan dalam komunikasi, missal: berbicara dan memahami bahasa.

2. Kesulitan dalam berhubungan dengan orang lain atau objek di sekitarnya serta menghubungkan peristiwaperistiwa yang terjadi. 
3. Bermain dengan mainan atau benda-benda lain secara tidak wajar.

4. Sulit menerima perbahan pada rutinitas dan lingkungan yang dikenali.

5. Gerakan tubuh yang berulang-ulang atau adanya polapla perilaku yang tertentu.

Para penyandang autism beserta spektrumnya angat beragam baik dalam kemampuan yang dimiliki, tingkat intelegensi, maupun perilakunya. Bebarapa diantaranya ada yang tidak "berbicara", sedangkan bebarapa lainnya mungkin terbatas bahasanya sehingga sering ditemukan mengulang-ulang kata atau kalimat. Mereka yang memiliki kemampuan bahasa yang tinggi umumnya menggunakan tema-tema terbatas dan sulit memahami konsep-konsep yang abstrak. Dengan demikian, selalu terdapat individualitas yang unik dari individu-individu penyandangnya.

Terlepas dari bebagai karatkeristik di atas, terdapat arahan dan pedoman bagi para orangtua dan para praktisi untuk lebih waspada dan peduli terhadap gejala-gejala yang terlihat. The National Institute of Child Healt and Human Development (NICHD) di Amerika menyebutkan lima jenis perilaku yang harus diwaspadai dan perlunya evaluasi lenih lanjut:

1. Anak tidak berguman hingga usia 12 bulan.

2. Anak tidak memperlihatkan kemampuan gestural (menunjuk dada, menggenggam) hingga usia 12 bulan.

3. Anak tidak mebgucapkan spatah katapun hingga usia 16 bulan.

4. Anak tidak mampu menggunakan dua kalimat secara spontan di usia 12 bulan.

5. Anak kehilangan kemampuan berbahasa dan interaksi social pada usia tertentu. 
Adanya kelima "lama merah" di atas tidak berarti bahwa anak tersebut menyandang autism, tetapi karena karakteristik gangguan autism yang beragam maka seorang anak harus mendapatkan evaluasi secara multidisipliner yang dapat meliputi; neurolog, psikolog, pediatric, terapi wicara, pedagog, dan profesi lainnya yang memahami persoalan autisme

Gejala autism dapat sangat ringan (mild), sedang (moderate), hingga parah (severe), sehingga masyarakat mungkin tidak menyadari seluruh keberadaannya. Parah atau ringannya gangguan sering kemudian dipararelkan dengan keberfungsian. Dikatakan oleh para ahli bahwa anak-anak dengan autisme dengan tingkat intelgensi dan kognitif rendah, tidak berbicara (nonverbal), memiliki perilaku menyakiti diri sendiri, serta menunjukkan sangat terbatasnya minat dan rutinitas yang dilakukan maka maka mereka diklasifikasikan sebagai low functioning autism. Sementara mereka yang menunjukkan fungsi kognitid dan intelegensi yang tinggi, mampu menggunakan bahasa dan bicaranya secara efektif serta menujukkan kemampuan mengikuti rutinitas yang umum diklasifikasikan sebagai high functioning autism.

Dua dikotomi dari karakteristik gangguan sesungguhnya akan sangat berpengaruh pada implikasi pendidikan maupun model-model treatment yang diberikan pada penyandang autisme.

\section{Penanganan Autisme di Indonesia}

Intensitas dari treatment perilaku pada anak dengan autism merupakan hal penting, namun persoalanpersoalan mendasar yang ditemui di Indonesia menjadi sangat krusial untuk diatasi lebih dahulu. Tanpa mengabaikan factor-faktor lain, bebrapa fakta yang 
dianggap relevan dengan persoalan penanganan masalah autism di Indonesia di antaranya:

1. Kurangnya tenaga terapis yang terlatih di Indonesia. Orangtua selalu menjadi pelopor dalam proses intervensi, sehingga pada awalnya pusat-pusat intervensi bagi anak dengan autisem dibangun berdasarkan kepentingan keluarga untuk menjamin kelangsungan pendidikan anak mereka sendiri.

2. Belum adanya pentunjuk treatment yang formal di Indonesia. Tidak cukup dengan hanya mengimplementasikan petunjuk treatment dari luar penerapannya tidak selalu sesuai dengan kultur kehidupan anak-anak Indonesia.

3. Masih banyak kasus-kasus autism yang tidak dideksi secara dini, sehingga ketika anak menjadi semakin besar maka semakin kompleks pula persoalan intervensi yang dihadapi orangtua. Para ahli yang mampu mendiagnosis autisme, informasi mengenai gangguan dan karakteristik autism, serta lembaga-lembaga formal yang memberikan layanan pendidikan bagi anak dengan autisme belum tersebar secara merata di seluruh Indonesia.

4. Belum terpadunya penyelenggaraan pendidikan bagi anak dengan autisme di sekolah. Dalam Pasal 4 UU No.20/2003 tentang SISDIKNAS telah diamanatkan pendidikan yang demikratis dan tidak diskriminatif dengan menjunjung tinggi hak asasi manusia. Dukungan ini membuka peluang yang besar bagi para penyandang autism untuk masuk dalam sekolah umum (inklusi), karena hamper 500 sekolah negeri telah diarahkan oleh pemerintah untuk menyelenggarakan inklusi.

5. Permasalahan akhir yang tidak kalah pentingnya adalah minimnya pengetahuan baik baik secara klinis maupun praktis, yang didukung dengan validitas data secara empirik dari penanganan-penanganan masalah autism di 
Indonesia. Studi dan penelitian autism selain membutuhkan dana yang besar juga harus didukung oleh validitas data empirik, namun secara etis tidak ada orangtua yang menginginkan anak mereka menjadi percobaan dari suatu metodologi tertentu.

\section{Terapi bagi Individu dengan Autisme}

Beberapa jenis terapi bersifat tradisonal dan telah teruji dari waktu ke waktu, semntara terapi lainnya mungkin saja belum muncul. Tidak seperti gangguan perkembangan lainnya, tidak banyak petunjuk treatment yang telah dipublishkanapalagi prosedur yang standar dalam menangani autisme. Para ahli sependapat bahwa terapi harus dimulai sejak sejak awal dan harus diarahkan pada hambatan maupun keterlambatan yang secara umum dimiliki setiap anak autis, misalnya komunikasi dan persoalan-persoalan perilaku. Treatment yang komperhensif umumnya meliputi: terapi wicara (speech therapy), okupasi terapi (occupational therapy) dan Applied Behavior Analysis (ABA) untuk mengubah serta memodifikasi perilaku.

Berikut ini adalah uraian sederhana dari berbagai iteratur yang ada dan ringkasan penjelasan yang tidak menyeluruh dari berbagai treatment yang diakui saat ini.

- Educational treatment, meliputi, terapi tidak terbatas pada: Applied Behavior Analysis (ABA) yang prinsipprinsipnya digunakan dalam penelitian lovaas, sehingga sering disamakan dengan discrete trial training atau intervensi perilaku intensif.

- Pendekatan developmental yang dikaitkan dengan pendidikan yang dikenal sebagai flooritime.

- TEACCH (Treatment and Educational of Autistic and Related Communication-Handicapped Chlidren). 
- Biological treatment, meliputi terapi anak terbatas pada: diet, pemberian vitamin dan pemberian obatobatan untuk mengurangi perilaku tertentu (agresivitas, hiperaktif, melukai diri sendiri, dan sebagainya)

- Specch-language therapy (terapi wicara), mrliputi, tidak terbatas pada usaha penanganan gangguan asosiasi dan gangguan proses audiotori/pendengaran.

- Komunikasi, peningkatan kemampuan komunikasi seperti PECS (Picture Exchange Comunication System), bahasa isyarat, strategi visual menggunakan gambar dalam berkomunikasi dan pendukung-pendukung komunikasi lainnya.

- Pelayanan autism intensif, meliputi kerja tim dari berbagai disiplin ilmu yang memberikan intervensi baik di rumah, maupun lingkungan social lainnya.

- Terapi yang bersifat sensoris, meliputi, tetapi tidak terbatas pada occupational therapy (OT), dan audiotory integration training (AIT).

Dengan adanya berbagai jenis terapu yang dapat dipilih oleh orangtua, maka sangat penting bagi mereka untuk memilih salah satu jenis terapi yang dapat meningkatkan funsionalitas anak dan mengurangi gangguan serta hambatan autism. Sangat disayangkan, masih minim data ilmiah yang mampu mendukung berbagai jenis terapi yang dapat dipilih orangtua di Indonesia saat ini. Fakta menyebutkan bahwa sangat sulit membuat suatu penelitian mengenai autism. Sangat banya variabel-variabel yang dimiliki anak, dari tingkat keparahan gangguan hingga lingkungan sekitarnya dan belum lagi ketika ada, di dalamnya untuk membuat suatu penelitian itu terkontrol.

Tidak ada satupun jenis terapi yang berhasil bagi semua anak. Tetapi harus disesuaikan dengan kebutuhan anak, berdasarkan pada potensinya, kekurangannya dan 
minat anak itu sendiri. Terapi harus dilakukan secara multidisplin ilmu, misalnya menggunakan okupasi terapi, terapi wicara, dan terapi tingkah laku sebagai basisnya. Tenaga ahli yang menangani anak harus mampumengarahkan pilihan-pilihan anda terhadap berbagai jenis terapi yang dipilih oleh orangtua maupun keluarga sungguh-sunggu akan berjalan efektif.

Namun demikian, tentukan salah satu jenis terapi dan laksanakan secara konsisten, bila tidak terlihat perubahan atau kemajuan selama tiga bulan dapat melakukan perubahan terapi. Bila terlihat kemajuan yang signifikan selama tiga bulan makabentuk intervensi lainnya dapat ditambahkan. Tetap bersikap objektif dan tanyakan kepada ahli bila terjadi perubahan-perubahan perilaku lainnya.

\section{Prognosis}

Diperkirakan terdapat 400.000 individu autisme di Amerika. Sejak tahun 80-an, bayi-bayi yang lahir di California-AS, diambil darahnya dan disimpan di pusat penelitian autisme. Penelitian dilakukan oleh Terry Phillips, seorang pakar kedokteran saraf dari Universitas George Washington. Dari 250 contoh darah yang diambil, ternyata hasilnya mencengangkan; seperempat dari anak-anak tersebut menunjukkan gejala autis. National Information Center for Children and Youth with Disabilitas (NICHCY) memperkirakan bahwa autism dan PDD pada tahun 2000 mendekati 50-100 per 10.000 kelahiran. Penelitian Frombonne (Study Frombonne:2003) menghasilkan prevalensi dari autisme beserta spektrumnya (Autism Spectrum Disorder/ ASD) adalah:60/10.000-best current estimate dan terdapat 425.000 penyandang ASD yang berusia di bawah 18 tahun di Amerika. Di Inggris, data terbaru 62.6/10.000 ASD. 
Autisme secara umum telah diketahui terjadi empat kali lebih sering terjadi pada anak laki-laki dibandingkan anak perempuan. Hingga saat ini penyebabnya belum diketahui secara pasti. Saat ini para ahli terus menembangkan penelitian mereka untuk mengetahui sebabnya, sehingga merekapun dapat menemukan "obat" yang tepat untuk mengatsi fenomena ini. Bidang-bidang yang menjadi fokus utama dalam penelitian para ahli, meliputi; kerusakan secara neurologis dan ketidakseimbangan dalam otak yang bersifat biokimia. Dr. Ron Leaf saat melakukan seminar di Singapura pada 2627 Maret 2004, menyebutkan beberapa factor penyebab autisme, yaitu:

- Genetic susceptibility-different genes may be responsible in different families.

- Chromosome 7-specch/language chromosome.

- Variety of problem in pregnancy at birth or even birth.

Meskipun para ahli dan praktisi di bidang autisme tidak selamanya dapat menetujui atau bahkan sependapat dengan penyebab di atas. Hal terpenting yang perlu dicatat melalui hasl penelitian terdahulu adalah bahwa gangguan autism disebabkan oleh faktor-faktor yang bersifat psikologis, misalnya karena orangtua tidak menginginkan anak ketika hamil.

\section{Bagaimana di Indonesia?}

Belum ditemukan data yan akurat mengenai keadaan sesungguhnya di Indonesia. Namun dalam suatu wawancara di koran KOMPAS; Dr. Melly Budhiman, seorang psikiater anak dan ketua Yayasan Autisme Indonesia menyebutkan adanya peningkatan yang luar biasa. "Bila sepuluh tahun yang lalu jumlah penyandang autisme diperkirakan satu per 5.000 anak, sekarang meningkat 
menjadi satu per 500 anak" (KOMPAS:2000). Tahun 2000 yang lalu, Dr. Ika Widyawati memperkirakan terdapat kurang lebih 6.900 anak penyandang autisme di Indonesia. Jumlah terbut menurutnya stiap tahun mengalami peningkatan. Hal ini perl diwasapadai, karena jika penduduk di Indonesia mencapai lebih dari 160 juta, kirakira berapa orang yang terdata sungguh-sungguh menyandang autisme beserta spektrumnya?

\section{Perkembangan Peneltian Autisme}

Tahun 1960 penanganan anak dengan autisme secara umum didasarkan pada model psokodinamika, menawarkan harapan akan pemulihan melalui experiental manipulations (Rimland, 1964). Namun demikian model psikodinamika dianggap tidak cukup efektif. Pada pertengahan tahun 1960-an, terdapat sejumlah laporan penelitian bahwa pelau psikodinamik tidak dapat memberikan apa yang mereka janjikan (Lovaas, 1987). Melalui berbagai literature, dapat disebutkan beberapa ahli yang memiliki perbedaan fisiologis, variasi-variasi treatment, dan target-target khusus lainnya, seperti:

1. Rimland (194): Meneliti karakteristik orngatua yang memiliki anak dengan autism, seperti: pekerja keras, pintar, obsesif, rutin dan detail. Ia juga meneliti penyebab autisme yang menurutnya mengarah pada factor biologis.

2. Bettelheim (1976): ide penyebab autisme adalah adanya penolakan daro otangtua. Infantile autism disebabkan harapan orangtua untuk tidak memiliki anak, karena pada saat itu psikoterapi yang sangat berpengaruh, maka akan menginstitusionalkan 46 anak dengan autisme untuk keluar dari stress berat. Namun tidak dilaporkan secara detail kelnajutan dari hasil pekerjaannya tersebut. 
3. Delacato (1974): Autisme disebabkan oleh Brain Injured. Sebagai seornga fisioterapi maka Delacato memberikan treatment yang bersifat sensoris. Pengaruh ini kemudian berkembang pada Doman yang kemudian hari mengembangakan metode Gleen Doman.

4. Lovaas (1987): Mengaplikasikan dan menerapkan Behavior modification kepada anak-anak berkebutuhan khusus, termasuk anak dengan autisme di dalamnya. Ia membuat program intervensi bagi anak-anak berkebutuhan khusus yang dilakukannya di UCLA. Dari hasil program-program Lovaas, anak-anak dengan autisme mendapatkan program modifikasi perilaku yang kemudian berkembang secara professional dalam jurnal-jurnal psikologi.

Hingga saat ini terdapat banyak program, intervensi perilaku bagi ana dengan autism, setiap program memiliki berbagai variasi dan pegembangan-pengembangan sediri sesuai dengan penelitian-peneltian yang dilakukan.

\section{E. Gagasan Pendidikan Inklusi}

Pendidikan merupakan kebutuhan dasar setiap manusia untuk menjamin keberlangsungan hidupnya agar lebih bermartabat. Karena itu negara memiliki kewajiban untuk memberikan pelayanan pendidikan yang bermutu kepada setiap warganya tanpa terkecuali termasuk mereka yang memiliki perbedaan dalam kemampuan (difabel) seperti yang tertuang pada UUD 1945 pasal 31 (1). Namun sayangnya sistem pendidikan di Indonesia belum mengakomodasi keberagaman, sehingga menyebabkan munculnya segmentasi lembaga pendidikan yang berdasar pada perbedaan agama, etnis dan bahkan perbedaan kemampuan baik fisik maupun mental yang dimiliki oleh 
siswa. Jelas segmentasi lembaga pendidikan ini telah menghambat para siswa untuk dapat belajar menghormati realitas keberagaman dan masyarakat.

Selama ini anak-anak yang memiliki perbedaan kemampuan (difabel) disediakan fasilitas pendidikan khusus disesuaikan dengan derajat dan jenis difabelnya yang disebut dengan Sekolah Luar Biasa (SLB). Secara tidak disadari sistem pendidikan SLB telah membangun tembok eksklusifisme bagi anak-anak yang berkebutuhan khusus. Tembok eksklusifisme tersebut selama ini tidak disadari telah menghambat proses saling mengenal antara anakanak difabel dengan anak-anak non-difabel. Akibatnya dalam interaksi sosial di masyarakat kelompok difabel menjadi komunitas yang teralienasi dari dinamika sosial di masyarakat. Masyarakat menjadi tidak akrab dengan kehidupan kelompok difabel. Sementara kelompok difabel sendiri merasa keberadaannya bukan menjadi bagian yang integral dari kehidupan masyarakat di sekitarnya.

Seiring dengan berkembangnya tuntutan kelompok difabel dalam menyuarakan hak-haknya, maka kemudian muncul konsep pendidikan inklusi. Salah satu kesepakatan Internasional yang mendorong terwujudnya sistem pendidikan inklusi adalah Convention on the Rights of Person with Disabilities and Optional Protocol yang disahkan pada maret 2007.Pada pasal 24 dalam konvensi ini disebutkan bahwa setiap negara berkewajiban untuk menyelenggarakan sistem pendidikan inklusi di setiap tingkatan pendidikan. Adapun salah satu tujuannya adalah untuk mendorong terwujudnya partisipasi penuh difabel dalam kehidupan masyarakat. Namun dalam prakteknya sistem pendidikan inklusi di Indonesia masih menyisakan persoalan tarik ulur antara pihak pemerintah dan praktisi pendidikan, dalam hal ini para guru. 


\section{F. Sistem Pendidikan Anak Luar Biasa: AWAL Inklusi}

1. Sistem pendidikan segregasi

Sistem pendidikan dimana anak berkelainan terpisah dari sistem pendidikan anak normal. Penyelenggara sistem pendidikan segregasi dilaksanakan secara khusus dan terpisah dari penyelenggaraan pendidikan untuk anak normal.

Keuntungan sistem pendidikan segregasi:

a. Rasa ketenangan pada anak luar biasa.

b. Komunikasi yang mudah dan lancar.

c. Metode pembelajaran yang khusus sesuai dengan kondisi dan kemampuan anak.

d. Guru dengan latar pendidikan luar biasa.

e. Mudahnya kerjasama dengan multidisipliner.

f. Sarana dan prasarana yang sesuai.

Kelemahan sistem pendidikan segregasi:

a. Sosialisasi terbatas

b. Penyelenggaraan pendidikan yang relative mahal Bentuk-bentuk sistem pendidikan segregasi:

a. Sekolah Luar Biasa

b. Sekolah Dasar Luar Biasa

c. Kelas Jauh/Kelas Kunjung

d. Sekolah Berasrama

e. Hospital School

2. Sistem pendidikan sekolah intregasi

Sistem pendidikan bagi siswa luar biasa yang bertujuan memberikan pendidikan yang memungkinkan anak luar biasa memperoleh kesempatan mengikuti proses pendidikan bersama dengan siswa normal agar mengembangkan diri secara optimal. 
Keuntungan sistem pendidikan integrasi:

a. Merasa diakui kesamaan haknya dengan anak normal terutama dalam memperoleh pendidikan.

b. Dapat mengembangkan bakat, minat dan kemampuan secara optimal.

c. Lebih banyak mengenal kehidupan orang normal.

d. Mempunyai kesempatan untuk melanjutkan pendidikan kejenjang yang lebih tinggi.

e. Harga diri anak luar biasa meningkat.

f. Dapat menumbuhkan motivasi dalam belajar.

\section{G. Manfaat Sekolah Inklusi}

Meski sampai saat ini sekolah inklusi masih terus melakukan perbaikan dalam berbagai aspek, namun dilihat dari sisi idealnya sekolah inklusi merupakan sekolah yang ideal baik bagi anak dengan dan tanpa berkebutuhan khusus. Lingkungan yang tercipta sangat mendukung terhadap anak dengan berkebutuhan khusus, mereka dapat belajar dari interaksi spontan teman-teman sebayanya terutama dari aspek sosial dan emosional. Sedangkan bagi anak yang tidak berkebutuhan khusus memberi peluang kepada mereka untuk belajar berempati, bersikap membantu dan memiliki kepedulian. Disamping itu bukti bukti lain yang ada mereka yang tanpa berkebutuhan khusus memiliki prestasi yang baik tanpa merasa terganggu sedikitpun.

Penyelenggara sistem pendidikan inklusi merupakan salah satu syarat yang harus terpenuhi untuk membangun tatanan masyarakat inklusi (inclusive society). Sebuah tatanan masyarakat yang saling menghormati dan menjunjung tinggi nilai-nilai keberagaman sebagai bagian dari realitas kehidupan. Pemerintah melalui PP. No. 19 tahun 2005 tentang Standar Nasional Pendidikan, pasal 4 
(1)telah mendorong terwujudnya sistem pendidikan inklusi dengan menyatakan bahwa setiap satuan pendidikan yang melaksanakan pendidikan inklusi harus memiliki tenaga kependidikan yang mempunyai kompetensi menyelenggarakan pembelajaran bagi peserta didik dengan kebutuhan khusus. Undang-undang tentang pendidikan inklusi dan bahkan uji coba pelaksanaan pendidikan inklusinya pun konon telah dilakukan.

Sekolah inkusi adalah sekolah reguler yang mengkoordinasi dan mengintegrasikan siswa reguler dan siswa penyandang cacat adalah pentingnya pendidikan inklusi, tidak hanya memenuhi target pendidikan untuk semua dan pendidikan dasar 9 tahun, akan tetapi lebih banyak keuntunganya tidak hanya memenuhi hak-hak asasi manusia dan hak-hak anak tetapi lebih penting lagi bagi kesejahteraan anak, karena pendidikan inklusi mulai dengan merealisasikan perubahan keyakinan masyarakat yang terkandung dimanaakan menjadi bagian dari keseluruhan, dengan demikian penyandang cacat anak akan merasa tenang, percaya diri, merasa dihargai, dilindungi, disayangi, bahagia dan bertanggung jawab.

Inklusi terjadi pada semua lingkungan sosial anak, pada keluarga, pada kelompok teman sebaya, pada sekolah, pada institusi-institusi kemasyarakatan lainnya. Sebuah masyarakat yang melaksanakan pendidikan inklusi berkeyakinan bahwa hidup dan belajar bersama adalah cara hidup (way of life) yang terbaik, yang menguntungkan semua orang, karena tipe pendidikan ini dapat menerima dan merespon setiap kebutuhan individu anak. Dengan demikan sekolah atau pendidikan menjadi suatu lingkungan belajar yang ramah anak-anak. Pendidikan inklusi adalah sebuah sistem pendidikan yang memungkinkan setiap anak penuh berpartisipasi dalam kegiatan kelas reguler tanpa mempertimbangkan kecacatan 
atau karakteristik lainnya. Disamping itu pendidikan inklusi juga melibatkan orang tua dalam cara yang berarti dalam berbagai kegiatan pendidikan, terutama dalam proses perencanaan, sedang dalam belajar mengajar, pendekatan guru berpusat pada anak.

Indonesia Menuju Pendidikan inklusi secara formal dideklarasikan pada tanggal 11 agustus 2004 di Bandung, dengan harapan dapat menggalang sekolah reguler untuk mempersiapkan pendidikan bagi semua anak termasuk penyandang cacat anak. Setiap penyandang cacat berhak memperoleh pendidikan pada semua sektor, jalur, jenis dan jenjang pendidikan (pasal 6 ayat 1). Setiap penyandang cacat memiliki hak yang sama untuk menumbuh kembangkan bakat, kemampuan dan kehidupan sosialnya, terutama bagi penyandang cacat anak dalam lingkungan keluarga dan masyarakat (Pasal 6 ayat 6 UU RI No. 4 tahun 1997 tentang penyandang cacat). Disamping pendidikan atau sekolah reguler, pemerintah atau badan-badan swasta menyelenggarakan pendidikan atau sekolah khusus yang bisa disebut Sekolah Luar Biasa (SLB) untuk melayani beberapa jenis kecacatan. Tidak seperti sekolah reguler yang tersebar luas baik di daerah perkotaan maupun daerah pedesaan. SLB dan SDLB sebagian besar berlokasi di perkotaan dan sebagian kecil sekali yang berlokasi di pedesaan. Penyandang cacat anak untuk menjangkau SLB dan SDLB relatif sangat jauh hingga memakan biaya cukup tinggi yang tidak terjangkau penyandang cacat anak dari pedesaan. Ini pula masalah yang dapat diselesaikan oleh pendidikan atau sekolah inklusi, di samping memecahkan masalah golongan penyandang cacat yang merata karena diskriminasi sosial, karena sejak dini tidak bersama, berorientasi dengan yang lain.

Sejak tahun 2001, pemerintah mulai uji coba perintisan sekolah inklusi seperti di Provinsi Daerah 
Istimewa Yogyakarta dengan 12 sekolah di daerah Gunung Kidul dan di Provinsi daerah Khusus Ibukota Yogyakarta dengan 35 sekolah. Pada sekolah-sekolah reguler yang dijadikan perintis itu memang diuntukkan anak-anak lambat belajar dan anak-anak sulit belajar sehingga perlu mendapat pelayanan khusus. Karena masih dalam tahap rntisan sampai sekarang belum ada informasi yang berarti dari sekolah-sekolah tersebut.

\section{H. Lingkup Pengembangan Kurikulum Pendidikan Inklusi}

Kurikulum pendidikan inklusi menggunakan kurikulum sekolah reguler (kurikulum nasional) yang dimodifikasi (diimprovisasi) sesuai dengan tahap perkembangan anak berkebutuhan khusus, dengan mempertimbangkan karakteristik (ciri-ciri) dan tingkat kecerdasannya. Modifikasi kurikulum dilakukan terhadap:

1. Alokasi waktu,

2. Isi/materi kurikulum,

3. Proses belajar-mengajar,

4. Sarana prasarana,

5. Lingkungan belajar dan,

6. Pengelolaan kelas.

Modifikasi/pengembangan kurikulum pendidikan inklusi dapat dilakukan oleh Tim Pengembangan kurikulum yang terdiri atas guru-guru yang mengajar di kelas inklusi bekerjasama dengan berbagai pihak yang terkait, terutama guru pembimbing khusus (guru Pendidikan Luar Biasa) yang sudah berpengalaman mengajar di Sekolah Luar Biasa, dan ahli Pendidikan Luar Biasa (Orthopaedagog), yang yang dipimpin oleh Kepala Sekolah Dasar Inklusi (Kepala SD Inklusi) dan sudah dikoordinir oleh Dinas Pendidikan. 


\section{Pelaksanaan Pengembangan Kurikulum sekolah inklusi}

\section{Modifikasi alokasi waktu}

Modifikasi alokasi waktu disesuaikan dengan mengacu pada kecepatan belajar siswa. Misalnya materi pelajaran (pokok bahasan) tertentu dalam kurikulum reguler (Kurikulum Sekolah Dasar) diperkirakan alokasi waktunya selama 6 jam. Untuk anak berkebutuhan khusus yang memiliki intelegensi di atas normal (anak berbakat) dapat dimodifikasi menjadi 4 jam.

Sedangkan untuk anak berkebutuhan khusus yang memiliki intelegensi relatif normal dapat dimodifikasi menjadi sekitar 8 jam; demikian juga untuk anak berkebutuhan khusus yang memiliki intelegensi di bawah normal (anak lamban belajar) dapat dimodifikasi menjadi 10 jam atau lebih; dan untuk anak tunagrahita menjadi 18 jam atau lebih dan seterusnya.

\section{Modifikasi isi/materi}

Untuk anak berkebutuhan khusus yang memiliki intelegensi di atas normal, materi dalam kurikulum sekolah reguler dapat digemukkan (diperluas/diperdalam) dan/atau ditambah materi baru yang tidak ada di dalam kurikulum sekolah reguler, tetapi materi tersebut dianggap penting untuk anak berbakat. Untuk anak berkebutuhan khusus yang memiliki intelegensi relatif normal materi dalam kurikulum sekolah reguler dapat tetap dipertahankan, atau tingkat kesulitannya diturunkan sedikit.

Untuk anak berkebutuhan khusus yang memiliki intelegensi di bawah normal (anak lamban belajar/tunagrahita) materi dalam kurikulum sekolah reguler dapat dikurangi atau diturunkan tingkat 
kesulitannya seperlunya, atau bahkan dihilangkan bagian tertentu.

3. Modifikasi proses belajar-mengajar

Mengembangkan proses berfikir tingkat tinggi, yang meliputi analis, sintesis, evaluasi, dan problem solving, untuk anak berkebutuhan khusus yang memiliki intelegensi di atas normal. Menggunakan pendekatan student conterred, yang menekankan perbedaan individual setiap anak; lebih terbuka (divergent). Memberikan kesempatan mobilitas tinggi, karena kemampuan siswa di dalam kelas heterogen, sehingga mungkin ada anak yang saling bergerak kesana-kemari, dari satu kelompok ke kelompok lain.

Menerapkan pendekatan pembelajaran kompetitif seimbang dengan pendekatan pembelajaran kooperatif. Melalui pendekatan pembelajaran kompetitif anak dirangsang untuk berprestasi setinggi mungkin dengan cara berkompetisi secara fair. Melalui kompetisi, anak akan berusaha seoptimal mungkin untuk berprestasi yang terbaik. Namun, dengan pendekatan pembelajaran kompetitif ini, ada dampak negatifnya, yaitu mungkin "ego-nya" akan berkembang kurang baik anak akan dapat menjadi egois.

Untuk menghindari hal ini, maka pendekatan pembelajaran kompetitif ini perlu diimbangi dengan pendekatan pembelajaran kooperatif. Melalui pendekatan pembelajaran kooperatif, setiap anak dikembangkan jiwa kerjasama dan kebersamaannya. Mereka diberi tugas dalam kelompok secara bersama mengerjakan tugas dan mendiskusikannya. Penekanannya adalah kerjasama dalam kelompok, dan kerjasama dalam kelompok ini yang dinilai. Dengan cara 
ini sosialisasi anak dan jiwa kerjasama serta saling tolong menolong akan berkembang dengan baik.

Dengan demikian, jiwa kompetisi dan jiwa kerjasama anak akan berkembang harmonis. Disesuaikan dengan berbagai tipe belajar siswa (ada yang bertipe visual; ada yang bertipe auditoris; adapula yang bertipe kinestetis). Tipe visual, yaitu lebih mudah menyerap informasi melalui indera penglihatan. Tipe auditoris, yaitu lebih mudah menyerap informasi melalui indera pendengaran. Tipe kinestetis, yaitu lebih mudah menyerap informasi melalui indera perabaan/gerakan. Guru hendaknya tidak monoton dalam mengajar sehingga hanya akan menguntungkan anak yang memiliki tipe belajar tertentu saja.

Dalam pelaksanaan pendidikan inklusi melalui sekolah inklusi ditemukan berbagai kendala dan kelemahan diantaranya minimya sarana penunjang sistem pendidikan inklusi, terbatasnya pengetahuan dan keterampilan yang dimiliki oleh para guru sekolah inklusi menunjukkan betapa sistem pendidikan inklusi belum benar-benar dipersiapkan dengan baik. Apalagi sistem kurikulum pendidikan umum yang ada sekarang memang belum mengakomodasi keberadaan anak-anak yang memiliki perbedaan kemampuan (difabel). Sehingga seperti program pendidikan inklusi hanya terkesan programeksperimental.

Kondisi ini jelas menambah beban tugas yang harus diemban para guru yang berhadapan langsung dengan persoalan teknis di lapangan. Di satu sisi para guru harus berjuang keras memenuhi tuntutan hati nuraninya untuk mencerdaskan seluruh siswanya, sementara di sisi lain para guru tidak memiliki keterampulan yang cukup untuk menyampaikan materi pelajaran kepada siswa yang difabel. Alih-alih situasi kelas yang seperti ini 
bukannya menciptakan sistem belajar yang inklusi, justru menciptakan kondisi eksklusifisme bagi siswa difabel dalam lingkungan kelas reguler. Jelas ini menjadi dilema tersendiri bagi para guru yang di dalam kelasnya ada siswa difabel.

Jika pemerintah memang serius dalam melaksanakan program pendidikan inklusi, maka yang harus dilakukan adalah dengan menjalankan tahapantahapan pelaksanaan pendidikan inklusi secara konsisten mulai dari sosialisasi hingga evaluasi pelaksanaannya. Namun yang lebih penting dan secara langsung dapat dilakukan oleh para guru untuk mewujudkan pendidikan inklusi adalah dengan menciptakan suasana belajar yang saling mempertumbuhkan (cooperative learning). Cooperative learning akan mengajarkan para siswa untuk dapat saling memahami (mutual understanding) kekurangan masing-masing temannya dan peduli (care) terhadap kelemahan yang dimiliki teman sekelasnya. Dengan demikian maka sistem belajar ini akan menggeser sistem belajar persaingan (competitive learning) yang selama ini diterapkan di dunia pendidikan kita. Dalam waktu yang bersamaan competitive learning dapat menjadi solusi efektif bagi persoalan yang dihadapi oleh para guru dalam menjalankan pendidikan inklusi. Pada akhirnya suasana belajar cooperative ini diharapkan bukan hanya menciptakan kecerdasan otak secara individual, namun juga mengasah kecerdasan dan kepekaan sosial para siswa. 


\section{DAFTAR PUSTAKA}

Mangunsong, F. 1998. Psikologi dan Pendidikan Anak Luar Biasa. LPSP3UI

Delphie, Bandi. 2006. Pembelajaran Anak Berkebutuhan Khusus. Bandung: Refika Aditama.

Abdurrahman, Mulyono. 1999. Pendidikan Bagi Anak Berkesulitan Belajar. Jakarta: Rineka Cipta.

Wardani, I.G.A.K. 2007. Pengantar Pendidikan Luar Biasa. Jakarta: Universitas Terbuka.

Hamalik, Oemar. 2007. Proses Belajar Mengajar. Jakarta: Bumi Aksara.

Http://kukuhsaputra.student.umm.ac.id/makalah-

pendidikan, diunduh pada 13 Agustus 2017

Joko Yuwono, 2009, Memahami Anak Autistik (Kajian Teoritik dan Empirik), (Bandung: Alfabeta)

Buku paket PJJ, 2007, Pendidikan anak berkebutuhan khusus, Direktorat pendidikan tinggi, Jakarta

Jamila K.A., Muhammad, 2008, Special Education for special children (Panduan Pendidikan Khusus Anak-anak dengan ketunaan dan learning disabilities, cet.I (Jakarta:Hikmah)

Hamzah B.Uno dan Masri Kuadrat, 2009, Mengelola kecerdasan dalam pembelajaran:sebuah konsep pembelajaran berbasis kecerdasan, cet, I (jakarta: Bumi Aksara)

Ratih Zimmer Gandasetiawan, 2011, Mendesain karakter anak melalui sensimotor, cet.2, (Jakarta: Gunung Mulia) 
Mukhtar Latif dkk, 2014, Orientasi Baru Pendidikan anak usia dini:Teori dan Aplikasi, (Jakarta: Kencana Prendamedia Group)

Direktorat Pendidikan Anak Usia Dini, Direktorat Jenderal Pendidikan Luar Sekolah dan Pemda, Konsep Dasar Pendidikan Anak Usia Dini, Departemen Pendidikan Nasional, Jakarta, 2004

Direktorat Pendidikan Anak Usia Dini, Direktorat Jenderal Pendidikan Luar Sekolah dan Pemda, Acuan Menu Pembelajaran pada Pendidikan Anak Usia Dini, Departemen Pendidikan Nasional, Jakarta, 2002

Abd. Rahman Abdullah, Aktualisasi Konsep Dasar Pendidikan Islam; Rekonstruksi Pemikiran dalam Tinjauan Filsafat Pendidikan Islam, UII Press, Yogyakarta, 2001

Louay Safi, The Foundation of Knowledge; a Comparative Study in Islamic and Western Methods of Inquiry, International Institute of Islamic Thought, Kuala Lumpur, 1996, hlm. 155, lihat juga dalam Popper, "The Defence of Rationalisme" Selection, David Miller (Ed.), Princeton, New Jersey, 1985

Direktorat Pendidikan Anak Usia Dini, Direktorat Jenderal Pendidikan Luar Sekolah dan Pemda, Pentingnya sosialisasi Program PADU, Departemen Pendidikan Nasional, Jakarta, 2004

Undang-undang Sisdiknas edisi terbaru 2012, (Bandung:Fukosindo, 2012)

Direktorat Pendidikan Anak Dini Usia, Direktorat Jenderal Pendidikan Luar Sekolah, Konsep Dasar Pendidikan Anak Usia Dini, Direktorat Pendidikan Anak Usia Dini, Jakarta, 2004 
Imam Musbikin, 2010, Buku Pintar PAUD:Tuntunan Lengkap dan praktis para Guru PAUD, (Jogjakarta: Laksana),

Departemen Pendidikan Nasional, Beyond enters and Circles Time (BCCT); Pendekatan Sentra dan Saat Lingkaran dalam Pendidikan Anak Usia Dini, Direktorat Jenderal Pendidikan Luar Sekolah Direktorat Pendidikan Anak Usia Dini, Jakarta, 2006,lihat juga dalam Yayasan Pendidikan Muslimat NU Bina Bakti Wanita Pusat (YPMNU), Kurikulum PAUD Formal dan Non Formal, Direktorat Jenderal Pendidikan Islam Direktorat Pendidikan Madrasah bekerja sama dengan YPMNU, Jakarta, 2007

Yuliani Nuraini Sujiono, Konsep Dasar Pendidikan Anak Usia Dini

Fasli Jalal, Arah kebijakan nasional pendidikan anak usia dini (jalur pendidikan nonformal), Jakarta

M. Fadlillah., dkk, 2014, Edutainment Pendidikan Anak Usia Dini: Menciptakan pembelajaran menarik, kreatif dan menyenangkan, (Jakarta: Kencana Prenadamedia Group)

Conny R. Semiawan dan Frieda Mangunsong, 2010, Keluarbiasaan Ganda (Twice Expectionality) Mengeksplorasi, mengenal, mengidentifikasi dan Menanganinya, (Jakarta: Kencana). 


\section{Tentang Penulis}

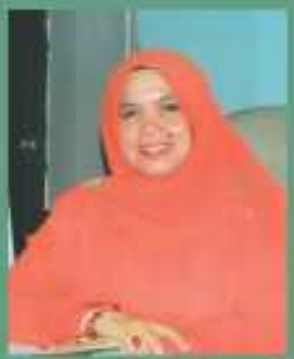

Dr.Zaitun, M.Ag, dilahirkan di Teluk Nilap, 10 Mei 1972. Menamatkan SD pada tahun 1985 , penulis melanjutkan studinya di Mts Muallimin Yayasan Haji Abdullah Rantau Panjang KIrl Kuou tahun 1988. Setelah Itu penulis melanjutkan ke Pondok Pesantran Modern KH. Dahlan Sipirok Tapanuli Selatan. Pada tahun 1996, penulis menyelesaikan S1 di

IAIN Sulthan Syarif Qasim Fekanbaru dan melan]utkan Ke Program Pasca Sarjana di Universilas yang sa ma, tamat tahun 2003. Facla tahun 2013 penilis menyelesaikan S3 nya di IAIN Imam Doajol Padang, / urusan Pendidikan Islam dan mendapatkan gelar Dolktor: Selain sebagai dosen paca Program Studi Strata Satu (S1) Penulis dan Program Studi Strata 2 (S2) d. UIN Sultan Syarif Kasim Riau, Penulis juga akrif melakukan berbagai perelitian dan pengabdian masyarakat serta terlibat dalam berbagai organisasi sosial kemasyarakatan seperti: DPW Muslimat NU,DPP Al-Hidayah ProvinsiRiau, dan Himpaudi ProvinstRiau.

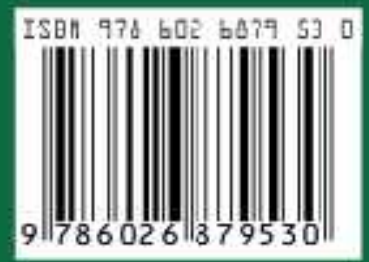

